\title{
20. RADIOLARIANS FROM THE WESTERN NORTH PACIFIC, LEG 57, DEEP SEA DRILLING PROJECT
}

\author{
Richard A. Reynolds, ${ }^{1}$ Rice University, Houston, Texas
}

\section{INTRODUCTION}

This is a preliminary investigation of radiolarianbearing sediments recovered from the four DSDP Leg 57 sites drilled on the west wall of the Japan Trench. The site locations are as follows:

\begin{tabular}{lllllrl}
\hline Site & Hole & Latitude & Longitude & $\begin{array}{c}\text { Water } \\
\text { Depth } \\
(\mathrm{m})\end{array}$ & $\begin{array}{c}\text { Pene- } \\
\text { tration } \\
(\mathrm{m})\end{array}$ & $\begin{array}{c}\text { Oldest } \\
\text { Sediment } \\
\text { Cored }\end{array}$ \\
\hline 438 & 438 & $40^{\circ} 37.75^{\prime} \mathrm{N}$ & $143^{\circ} 13.90^{\prime} \mathrm{E}$ & 1552 & 109.5 & lower Pliocene \\
& $438 \mathrm{~A}$ & $40^{\circ} 37.79^{\prime} \mathrm{N}$ & $143^{\circ} 14.15^{\prime} \mathrm{E}$ & 1558 & 878.0 & middle Miocene \\
& $438 \mathrm{~B}$ & $40^{\circ} 37.80^{\prime} \mathrm{N}$ & $143^{\circ} 14.80^{\prime} \mathrm{E}$ & 1564.5 & 1040.7 & lower Miocene \\
439 & 439 & $40^{\circ} 37.61^{\prime} \mathrm{N}$ & $143^{\circ} 18.63^{\prime} \mathrm{E}$ & 1656 & 1157.5 & Cretaceous \\
440 & 440 & $39^{\circ} 44.13^{\prime} \mathrm{N}$ & $143^{\circ} 55^{\prime} .74^{\prime} \mathrm{E}$ & 4509 & 73.0 & Pleistocene \\
& $440 \mathrm{~A}$ & $30^{\circ} 44.13^{\prime} \mathrm{N}$ & $143^{\circ} 55.74^{\prime} \mathrm{E}$ & 4509 & 139.5 & Pleistocene \\
& $440 \mathrm{~B}$ & $39^{\circ} 44.13^{\prime} \mathrm{N}$ & $143^{\circ} 55.74^{\prime} \mathrm{E}$ & 4509 & 814.0 & upper Miocene \\
441 & 441 & $39^{\circ} 45.05^{\prime} \mathrm{N}$ & $144^{\circ} 04.59^{\prime} \mathrm{E}$ & 5655 & 273.0 & lower Pliocene \\
& $441 \mathrm{~A}$ & $39^{\circ} 45.05^{\prime} \mathrm{N}$ & $143^{\circ} 04.59^{\prime} \mathrm{E}$ & 5644 & 662.0 & upper Miocene \\
& $441 \mathrm{~B}$ & $39^{\circ} 45.08^{\prime} \mathrm{N}$ & $143^{\circ} 04.60^{\prime} \mathrm{E}$ & 5635 & 687.0 & upper Miocene \\
\hline
\end{tabular}

The majority of the sedimentary material recovered is Neogene and contains assemblages of radiolarians rich and diverse enough to allow biostratigraphic analysis. From such an analysis, a Neogene radiolarian biozonation is proposed for the region studied.

Paleogene and Cretaceous strata were recovered at Site 439 , but the poor preservation and diversity of radiolarians inhibited analysis of these sediments. Reworking of Cretaceous radiolarians into Oligocene sediments (dated by Keller, this volume) lacking an Oligocene radiolarian fauna precluded age assignments in the lower portion of Hole 439.

Sites 438 and 440 provide excellent Neogene radiolarian sections and may prove invaluable for correlation of radiolarian events to those of other fossil groups, especially diatoms. The zonation proposed in this report is developed basically from these sections. Site 440 is especially appropriate for the recognition of Pliocene to Pleistocene zones because this interval is represented by an expanded sedimentary section. The continuous section recovered at Site 438 makes it useful for the lower Miocene to Recent interval.

\section{SCOPE}

Radiolarian biostratigraphy comprises the majority of this investigation. Preliminary radiolarian paleoecologic results are reported herein, but a more detailed analysis is required and is forthcoming (Reynolds, in preparation).

The provincialism of radiolarians has been well documented and has inhibited worldwide correlations. Materi-

\footnotetext{
1 Present address: Getty Oil Company, Exploration and Production Research Center, Houston, Texas.
}

als recovered on DSDP Leg 57 has afforded the opportunity to correlate a number of the "warm"'-water or low-latitude radiolarian datums of Riedel and Sanfilippo $(1970,1977,1978)$ to the "cold"-water or middle- or high-latitude radiolarian datums of Hays (1970), Kling (1973), and Forman (1975). This has led to the development of a Neogene radiolarian biozonation containing datums of both "warm"- and "cold"-water radiolarians. Because this is a preliminary investigation, only the most ostensive and consistent datums are reported and used in the zonation.

\section{METHODOLOGY AND PRESENTATION OF RESULTS}

Samples were prepared for microscopic examination using the standard radiolarian preparation techniques of Riedel (1957) and Riedel and Sanfilippo (1977). When possible, three samples per core, with an interval of approximately three meters between them, were examined. Preliminary measurements and observations were made from these samples.

Species abundance (Tables 1-8) was determined by counting the number of individuals of a particular species per slide. Two slides were made for each sample and species categorized as follows: $1=1-4$ individuals per slide; $2=5-9$ individuals per slide; $3=10-14$ individuals per slide; $4=15-24$ individuals per slide; $5=$ 25-34 individuals per slide; and $6=$ more than 35 individuals per slide. A dot $(\cdot)$ indicates that only one isolated individual was observed in the two slides. Not all of the species observed in this study are reported herein-only those with apparent biostratigraphic importance. The most consistently abundant groups encountered are the spongodisciids, actinomiids, and litheliids.

Relative preservation and total abundance of the radiolarian assemblages examined were also determined for each sample. Preservation is ranked as follows: Poor $(\mathrm{P})=$ over 50 per cent of the specimens are broken and/or show signs of dissolution; moderate $(M)=50$ to 25 per cent of the specimens are broken and/or show signs of dissolution; and good $(\mathrm{G})=$ less than 25 per cent of the specimens are broken and/or show signs of dissolution. Abundance is characterized as follows: rare $(\mathrm{R})=$ radiolarians comprise less than 5 per cent of all the sediment material on the slide; few $(F)=$ radiolarians comprise between 5 to 33 per cent of all the sediment material on the slide; and common $(\mathrm{C})=$ radiolarians comprise more than 33 per cent of all the sediment material on the slide. To make these ratings meaningful the following average values were assigned: A slide with moderate preservation and an abundance measurement of few contains approximately 200 radiolarians, with a range of from about 120 to 280 . 
TABLE 1

Abundance/Occurrence Chart, DSDP Hole 438

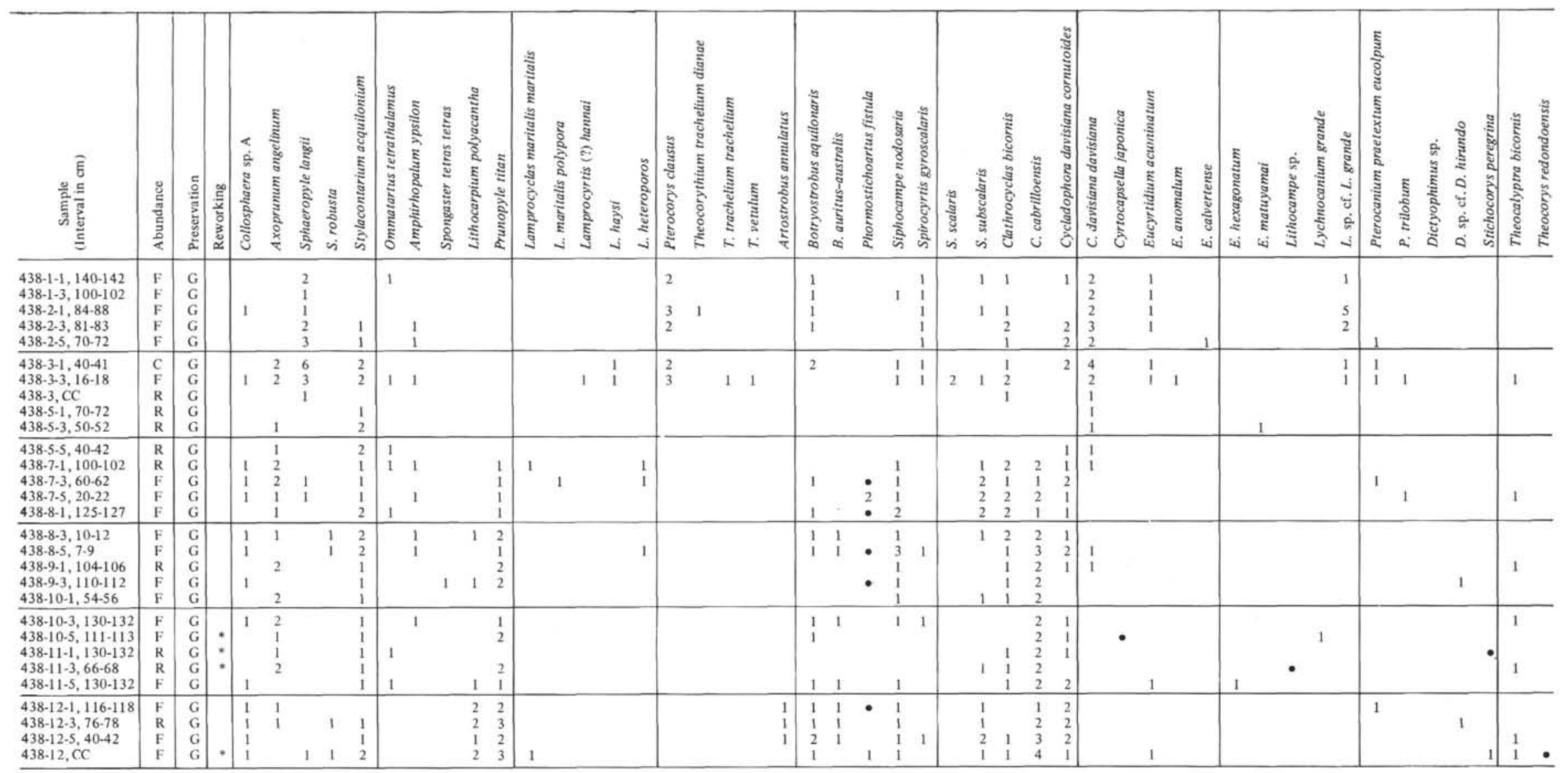


Tables 1 through 8 summarize the foregoing measurements and observations and give the reader an idea of relative abundance and consistency of occurrence of the species used for biostratigraphic analysis. It is from these tables that the list of datums recognized in each hole is constructed (see Table 9).

Table 9 was developed using the maximum range of the selected species and placing the first (B) or last (T) occurrence datum of that species in its proper relative position, except when there was obvious reworking. Transitions from one species to another-for example, from Stichocorys delmontensis to Stichocorys peregrina-are also reported and represent the stratigraphic level at which the descendant became more abundant upsection, in the same sense as the evolutionary boundaries of Riedel and Sanfilippo (1971). Core barrel and section numbers, with their associated depths in meters below the sediment surface, indicate the location of each datum recognized in the different holes. Depths should increase from the top of the table to the bottom. Arrows indicate if a datum is depressed (1) or elevated (I) in the hole relative to the observed maximum range of the species. Elevations of bottoms and depressions of tops are accounted for by poor representation of that particular species in the hole. The number of holes containing arrows for a particular datum indicates the reliability of that datum.

Range charts (Figures 1, 2, and 3) are produced from Tables 1 to 9 . Figure 1 is a range chart for Hole 438A. The dashed lines indicate the maximum range of a species as interpreted from the other holes. Figure 2 shows the range of several Pleistocene species found in the upper part of Holes 440 and $440 \mathrm{~A}$ and its relationship to other radiolarian biozonations. A range chart is produced for the lower portion of Hole 438B for the middle and lower Miocene (see Figure 3). The dashed lines are inferred ranges extrapolated from Holes 438A and 439. These charts are presented to aid in the use of the proposed radiolarian zonation.

\section{BIOSTRATIGRAPHY}

The radiolarian zonations proposed by Riedel and Sanfilippo (1970, 1971, 1977, 1978) were not applicable to the samples examined from Leg 57 , primarily because of the influx of cold water into the study area by the Oyashio Current from the north. However, several of the datums in their zonations were present and are used to correlate these zonations to the one developed in this study (see Figure 4).

As an alternative to applying the Riedel and Sanfilippo zonations, those developed and/or used by Hays (1970), Kling (1973), and Forman (1975) were implemented. These biozonal schemes extend from upper Miocene to Recent. Older strata had previously been fitted into the zonal scheme of Riedel and Sanfilippo (Kling, 1973; Forman, 1975). These assignments relied on the presence of such warm-water radiolarians as Cannartus petterssoni and Ommatartus antepenultimus, which apper to invade high-latitude waters. Placement of strata into a radiolarian zone which does not contain the nominate species requires indirect correlation. For example,
Kling (1973) placed the lower portion of DSDP Site 173 in the Calocycletta costata Zone, though he lacked the nominate species, $C$. costata, and did not recognize the transition of Dorcadospiris dentata to D. alata. The presence of Cannartus violina indicated that this section might be of the Calocycletta costata Zone.

In order to avoid such difficulties, I have presented a new Neogene radiolarian biozonation. Correlation of the radiolarian zonation of Riedel and Sanfilippo (1977, 1978 ) to the zonation presented herein was furnished using the datums listed in Table 9. This Neogene radiolarian zonation is composed of 16 zones, 9 of which are new. Use of this temperate radiolarian zonation in other high- and low-latitude regions appears to be favorable, because it is based primarily on species present in warmwater as well as in cold-water regions. Therefore it may serve as a link between high- and low-latitude radiolarian zonations.

\section{Description of Zonation}

\section{Botryostrobus aquilonaris Zone (Hays, 1970)}

The base of the Botryostrobus aquilonaris Zone is defined by the last occurrence of Axoprunum angelinum. and the top extends into Recent sediments. The $B$. aquilonaris Zone as used herein is equivalent to the $\mathrm{Ar}$ tostrobium miralestensis Zone of Kling (1973), the $A$. tumidulum Zone of Forman (1975), and the Eucyrtidium tumidulum of Hays (1970). The last occurrence of Stylacontarium acquilonium occurs slightly above the base of this zone. An absolute age of $0.4 \mathrm{~m}$.y. has been assigned to the base of the zone by Hays (1970). Sites 438 (Sections 438-1-1-438-2-5 and 438A-1-1-438A-1, CC), 440 (Sections 440-1-1-440A-1-5), and 441 (Sections 441-1-1-441-1,CC) contain strata representing this zone.

\section{Axoprunum angelinum Zone (Kling, 1973)}

The top of this zone is defined by the last common occurrence of Axoprunum angelinum and its base by the last occurrence of Eucyrtidium matuyamai. It is equivalent to the Axoprunum angelinum Zones of Kling (1973) and Forman (1975) and the Stylatractus universus Zone of Hays (1970). The first occurrence of Lychnocanium sp. cf. $L$. grande occurs near its base. This zone is recognized at Sites 438 (Sections 438-3-1-438-5-1 and 438A-2-1-438A-3-5), 440 (Section 440A-3-1-440B$7-3$ ), and 441 (Section 441-2-1). Hays (1970) has correlated the base to the Jarmillo Event (0.9 m.y., Cox, 1969). Hence the zone is assigned to the Pleistocene.

\section{Eucyrtidium matuyamai Zone (Hays, 1970 emend. Kling, 1973)}

The base of this zone is defined by the transition of Eucyrtidium calvertense to E. matuyamai, and the top is equivalent to the base of the Axoprunum angelinum Zone. The Eucyrtidium matuyamai Zones of Kling (1973) and Forman (1975) are synonymous with it and correlate in part with Hays' (1970) E. matuyamai Zone. Sites 438 (Sections 438-5-3 and 438A-4-1-438A-4-5), 440 (Section 440B-7-5-440B-19-3), and 441 (Sections 
TABLE 2

Abundance/Occurrence Chart, DSDP Hole 438A

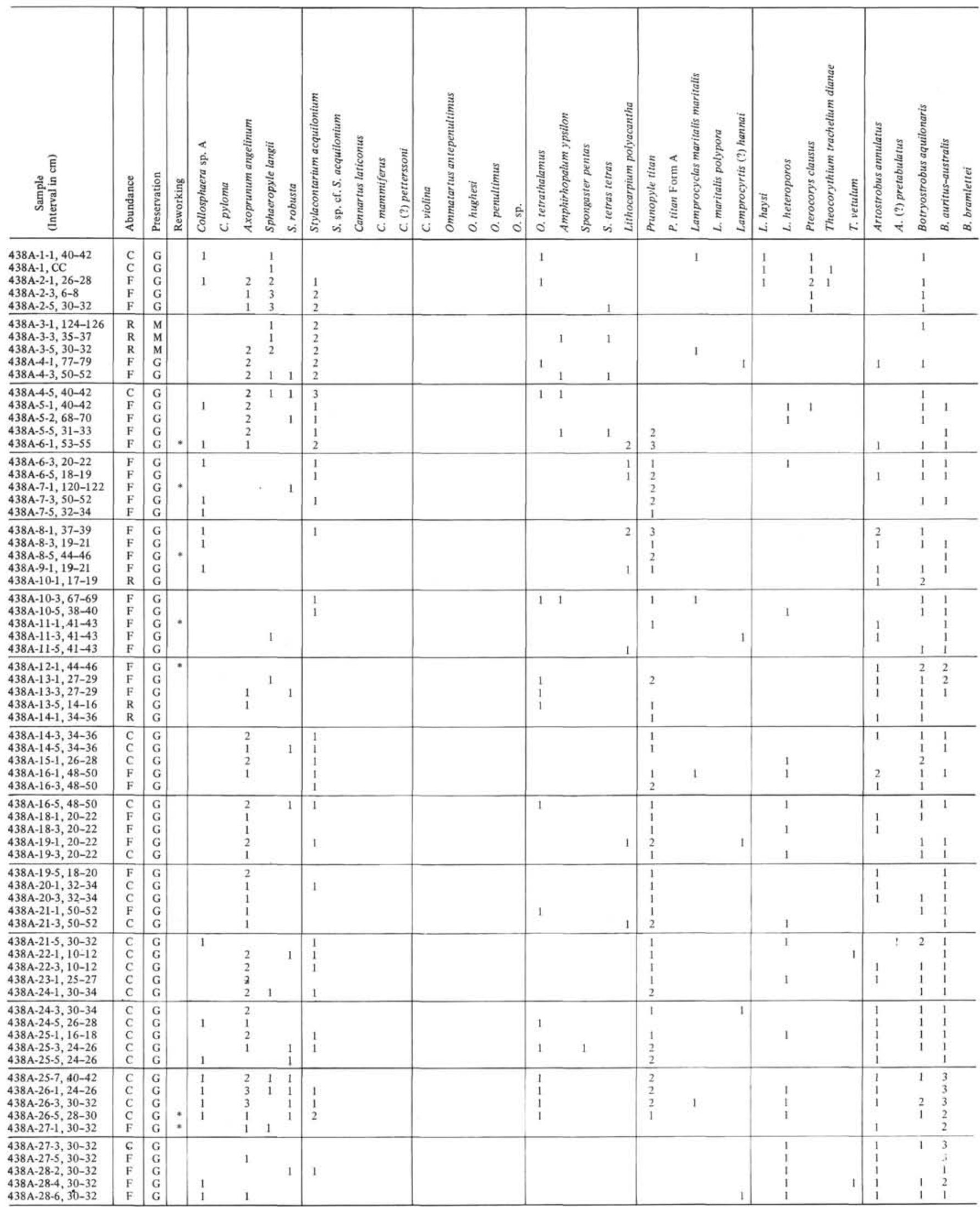


TABLE 2 - Continued

\begin{tabular}{|c|c|c|c|c|c|c|c|c|c|c|c|c|c|c|c|c|c|c|c|c|c|c|c|c|c|c|c|}
\hline 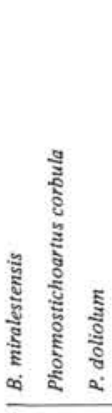 & $\underbrace{\frac{3}{2}}_{2}$ & 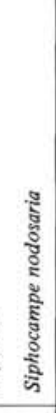 & 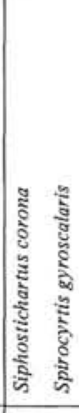 & 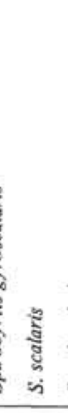 & 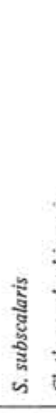 & 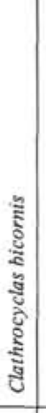 & 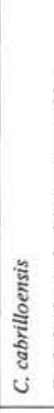 & 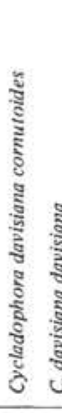 & 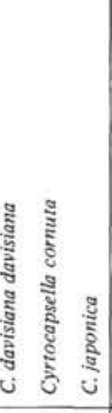 & 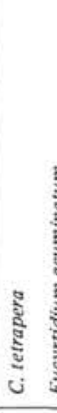 & 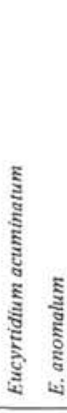 & 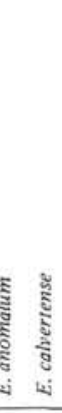 & 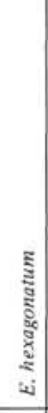 & 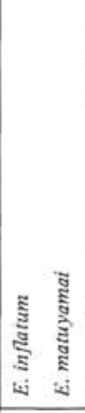 & 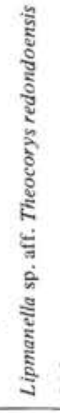 & 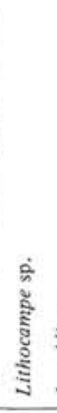 & 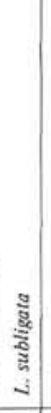 & 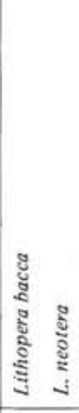 & 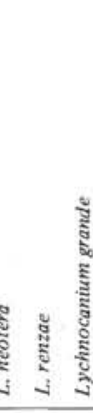 & 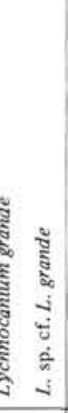 & 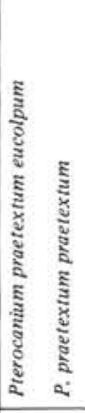 & 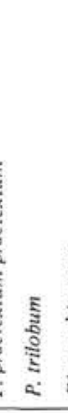 & 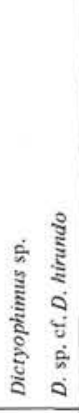 & 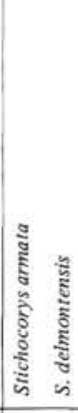 & 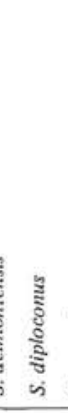 & 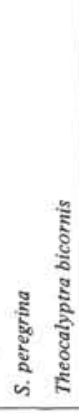 & 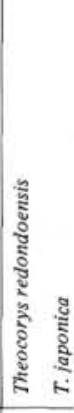 \\
\hline & & $\begin{array}{l}1 \\
1\end{array}$ & $\begin{array}{l}1 \\
1 \\
1 \\
\end{array}$ & $\begin{array}{l}1 \\
1 \\
\end{array}$ & $\begin{array}{l}1 \\
1 \\
2 \\
1 \\
1 \\
\end{array}$ & $\begin{array}{l}1 \\
2 \\
1 \\
1 \\
\end{array}$ & & $\begin{array}{ll}1 & 2 \\
1 & 2 \\
2 & 3 \\
2 & 2 \\
1 & 2 \\
\end{array}$ & $\begin{array}{l}2 \\
2 \\
3 \\
2 \\
2 \\
\end{array}$ & & $\begin{array}{l}1 \\
1\end{array}$ & $\begin{array}{l}1 \\
1\end{array}$ & & & & & & & & $\begin{array}{l}2 \\
2 \\
1 \\
1 \\
\end{array}$ & $\begin{array}{ll}1 & 1 \\
1 & 1\end{array}$ & $\begin{array}{l}1 \\
1\end{array}$ & & & & 1 & \\
\hline & & $\begin{array}{l}1 \\
1 \\
\end{array}$ & & & 1 & 1 & & $\begin{array}{ll} & 1 \\
1 & 1 \\
1 & 1 \\
1 & 2 \\
2 & 2 \\
\end{array}$ & $\begin{array}{l}1 \\
1 \\
1 \\
2 \\
2 \\
2\end{array}$ & & & & & $\begin{array}{l}1 \\
1 \\
\end{array}$ & & & & & & & 1 & - & & & & & \\
\hline & & $\begin{array}{l}1 \\
1 \\
1 \\
2 \\
\end{array}$ & & & $\begin{array}{l}1 \\
1\end{array}$ & \begin{tabular}{l|}
1 \\
2 \\
1 \\
1
\end{tabular} & $\begin{array}{l}1 \\
1 \\
1 \\
2 \\
\end{array}$ & $\begin{array}{ll}1 & 2 \\
1 & 2 \\
& 1 \\
& 1 \\
3 & 1 \\
\end{array}$ & $\begin{array}{l}2 \\
2 \\
1 \\
1 \\
1 \\
\end{array}$ & & $\begin{array}{l}1 \\
1\end{array}$ & & 1 & 1 & & & & & & & 1 & & & & & $\begin{array}{r}1 \\
\text { - } 1 \\
\end{array}$ & • \\
\hline & $\begin{array}{l}\bullet \\
\bullet \\
\end{array}$ & $\begin{array}{l}1 \\
1 \\
1 \\
1 \\
1 \\
\end{array}$ & & & $\begin{array}{l}1 \\
1\end{array}$ & 1 & $\begin{array}{l}1 \\
2 \\
1 \\
2 \\
\end{array}$ & $\begin{array}{ll}2 & 1 \\
1 & \\
2 & 1 \\
1 & \\
1 & \\
\end{array}$ & $\begin{array}{l}1 \\
1 \\
\end{array}$ & & & & & & & & & 1 & & & & & & & & $\begin{array}{r}1 \\
-\quad 1 \\
\end{array}$ & \\
\hline & • & 1 & & & 1 & 1 & $\begin{array}{l}2 \\
2 \\
2 \\
2 \\
2 \\
\end{array}$ & $\begin{array}{l}3 \\
2 \\
2 \\
2\end{array}$ & & & 1 & 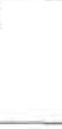 & & & & & & 1 & & & & & $\begin{array}{l}1 \\
1 \\
1\end{array}$ & & & $\begin{array}{r}1 \\
-\quad 1 \\
\end{array}$ & \\
\hline 1 & • & $\begin{array}{l}1 \\
1 \\
1 \\
1 \\
\end{array}$ & $\begin{array}{l}1 \\
1 \\
1 \\
\end{array}$ & & $\begin{array}{l}1 \\
1 \\
\end{array}$ & \begin{tabular}{l|}
2 \\
2 \\
2 \\
1 \\
1 \\
\end{tabular} & \begin{tabular}{|l}
3 \\
2 \\
2 \\
2 \\
2 \\
\end{tabular} & $\begin{array}{l}3 \\
2 \\
3 \\
2 \\
\end{array}$ & & & 1 & 1 & & & & & & & & & & & $\begin{array}{l}1 \\
1\end{array}$ & & & • & \\
\hline & 1 & $\begin{array}{l}3 \\
4 \\
3 \\
2 \\
2 \\
\end{array}$ & & & 1 & $\begin{array}{l}2 \\
1 \\
1 \\
1 \\
\end{array}$ & \begin{tabular}{|l}
1 \\
2 \\
2 \\
1 \\
\end{tabular} & $\begin{array}{l}2 \\
2 \\
2 \\
1 \\
1 \\
\end{array}$ & & & $\begin{array}{l}1 \\
1\end{array}$ & . & & & & & & $\begin{array}{l}1 \\
1 \\
1\end{array}$ & & & & & 1 & & & $\begin{array}{ll} & 1 \\
1 & 1 \\
1 & \\
1 & \\
& 1 \\
\end{array}$ & • \\
\hline${ }^{1} 1$ & . & $\begin{array}{l}3 \\
4 \\
3 \\
2 \\
2 \\
\end{array}$ & $\begin{array}{l}1 \\
1\end{array}$ & 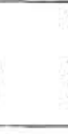 & $\begin{array}{l}1 \\
1 \\
1\end{array}$ & \begin{tabular}{l|}
1 \\
1
\end{tabular} & $\begin{array}{l}2 \\
2 \\
2 \\
2 \\
2 \\
\end{array}$ & $\begin{array}{l}2 \\
1 \\
1\end{array}$ & & & & & & & 1 & & 1 & & & & & & & $\begin{array}{l}1 \\
1 \\
\end{array}$ & & $\begin{array}{ll}1 & 1 \\
1 & \\
1 & \\
1 & \\
1 & 1 \\
\end{array}$ & \\
\hline & $\begin{array}{l}2 \\
1 \\
1 \\
1 \\
1 \\
\end{array}$ & $\begin{array}{l}3 \\
3 \\
3 \\
2 \\
\end{array}$ & 1 & & & $\begin{array}{l}1 \\
1\end{array}$ & $\begin{array}{l}2 \\
2 \\
2 \\
2 \\
2 \\
\end{array}$ & $\begin{array}{l}1 \\
2 \\
1 \\
2 \\
2 \\
\end{array}$ & & & $\begin{array}{l}1 \\
1\end{array}$ & & 1 & & & $\begin{array}{l}2 \\
1 \\
2\end{array}$ & $\begin{array}{l}1 \\
1 \\
1 \\
1\end{array}$ & & 1 & 1 & & & & 1 & & $\begin{array}{ll}2 & 2 \\
2 & 2 \\
3 & 2 \\
2 & 2 \\
1 & 1 \\
\end{array}$ & \\
\hline 1 & $\begin{array}{l}1 \\
1 \\
1 \\
1 \\
\end{array}$ & $\begin{array}{l}3 \\
3 \\
2 \\
3 \\
2 \\
\end{array}$ & $\begin{array}{l}1 \\
1 \\
\end{array}$ & 1 & $\begin{array}{l}1 \\
1 \\
\end{array}$ & 1 & $\begin{array}{l}3 \\
2 \\
1 \\
1 \\
2 \\
\end{array}$ & $\begin{array}{l}1 \\
1 \\
1 \\
1 \\
1\end{array}$ & & & $\begin{array}{ll}1 & \\
1 & \\
1 & 1 \\
\end{array}$ & & & & & $\begin{array}{l}2 \\
2 \\
1 \\
1 \\
1 \\
\end{array}$ & $\begin{array}{l}1 \\
1 \\
1 \\
1 \\
\end{array}$ & & & & & & & 1 & & $\begin{array}{ll}1 & 3 \\
2 & 2 \\
2 & 1 \\
2 & 1 \\
3 & 2 \\
\end{array}$ & \\
\hline 1 & 1 & $\begin{array}{l}3 \\
2 \\
3 \\
2 \\
2 \\
\end{array}$ & & & $\begin{array}{l}1 \\
1 \\
1 \\
1 \\
\end{array}$ & \begin{tabular}{l|}
1 \\
1 \\
1 \\
1 \\
1 \\
\end{tabular} & \begin{tabular}{|l}
2 \\
2 \\
2 \\
2 \\
2 \\
\end{tabular} & $\begin{array}{l}2 \\
1 \\
1 \\
1 \\
1 \\
\end{array}$ & & & $\begin{array}{l}1 \\
1 \\
\end{array}$ & & & & & $\begin{array}{l}1 \\
2 \\
1 \\
2 \\
2\end{array}$ & $\begin{array}{l}2 \\
1 \\
1\end{array}$ & & 1 & 1 & & & & $\begin{array}{l}1 \\
1 \\
1 \\
1\end{array}$ & & $\begin{array}{ll}2 & 2 \\
2 & 1 \\
2 & 2 \\
2 & 1 \\
& 1 \\
\end{array}$ & \\
\hline $\begin{array}{l}1 \\
1 \\
\end{array}$ & $\begin{array}{l}1 \\
1 \\
1 \\
1\end{array}$ & $\begin{array}{l}2 \\
2 \\
2 \\
2 \\
2 \\
\end{array}$ & $\begin{array}{l}1 \\
1 \\
\end{array}$ & 1 & 1 & $\begin{array}{l}1 \\
1 \\
\end{array}$ & $\begin{array}{l}1 \\
2 \\
3 \\
3 \\
3 \\
\end{array}$ & $\begin{array}{l}1 \\
1 \\
2 \\
1\end{array}$ & & & $1^{1}$ & & & & & $\begin{array}{l}1 \\
2 \\
3 \\
1 \\
2 \\
\end{array}$ & $\begin{array}{l}1 \\
1 \\
1\end{array}$ & & & & & 1 & & 1 & & $\begin{array}{ll}2 & 1 \\
2 & 1 \\
2 & 1 \\
3 & 2 \\
3 & 1 \\
\end{array}$ & \\
\hline 1 & 1 & $\begin{array}{l}2 \\
2 \\
2 \\
2 \\
1 \\
\end{array}$ & & $\begin{array}{ll} & 3 \\
1 & 3 \\
1 & 3 \\
\end{array}$ & $\begin{array}{l}3 \\
3 \\
2 \\
1 \\
\end{array}$ & $\begin{array}{l}2 \\
2 \\
1 \\
1 \\
1 \\
\end{array}$ & $\begin{array}{l}3 \\
3 \\
2 \\
2 \\
2 \\
\end{array}$ & $\begin{array}{l}1 \\
2 \\
2 \\
1\end{array}$ & & & $\begin{array}{l}1 \\
1 \\
1 \\
1 \\
1\end{array}$ & 1 & & & $\begin{array}{l}1 \\
1 \\
1\end{array}$ & $\begin{array}{l}1 \\
2 \\
2 \\
1 \\
1 \\
\end{array}$ & $\begin{array}{l}1 \\
2 \\
1 \\
1\end{array}$ & & 1 & 1 & & & & $\begin{array}{l}1 \\
1 \\
1 \\
1\end{array}$ & & $\begin{array}{ll}3 & 1 \\
3 & 2 \\
3 & 1 \\
2 & 1 \\
3 & 2 \\
\end{array}$ & • \\
\hline & 1 & $\begin{array}{l}1 \\
1 \\
1 \\
1 \\
1 \\
\end{array}$ & & & $\begin{array}{l}1 \\
1 \\
1 \\
1 \\
\end{array}$ & \begin{tabular}{l|l}
1 & \\
1 \\
1
\end{tabular} & $\begin{array}{l}3 \\
3 \\
2 \\
1 \\
2 \\
\end{array}$ & $\begin{array}{l}1 \\
1 \\
1\end{array}$ & & & $\begin{array}{l}1 \\
1 \\
1 \\
1 \\
\end{array}$ & & & & $\begin{array}{l}1 \\
1 \\
1 \\
2 \\
1\end{array}$ & $\begin{array}{l}1 \\
1 \\
1 \\
1\end{array}$ & $\begin{array}{l}1 \\
1 \\
1 \\
1\end{array}$ & & & & & & & $\begin{array}{l}1 \\
1 \\
1\end{array}$ & & $\begin{array}{ll}3 & 1 \\
3 & 1 \\
3 & 1 \\
1 & 1 \\
2 & 2 \\
\end{array}$ & $\begin{array}{l}1 \\
1 \\
1 \\
1\end{array}$ \\
\hline
\end{tabular}




\section{R. A. REYNOLDS}

TABLE 2-Continued

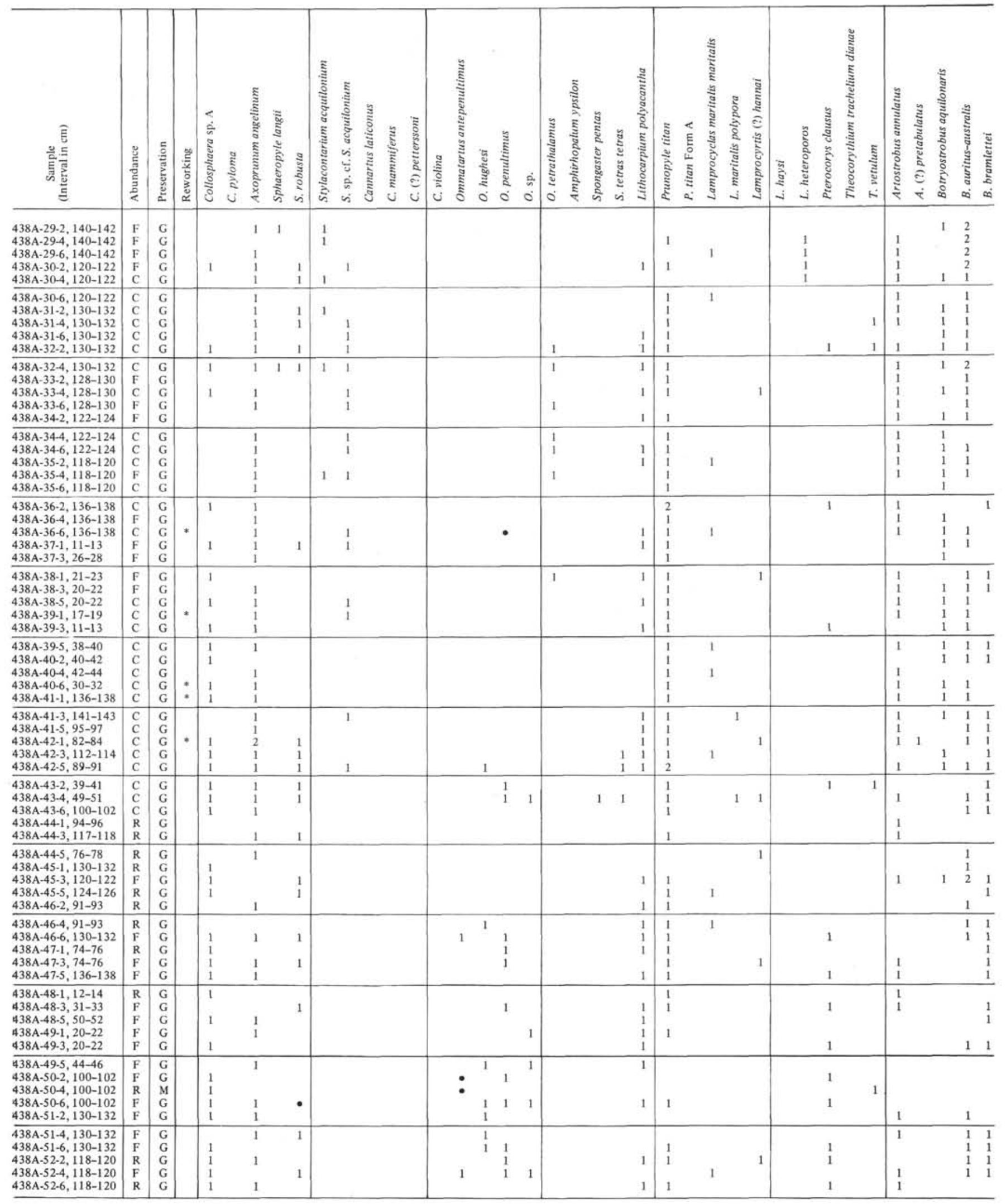


TABLE 2 - Continued

\begin{tabular}{|c|c|c|c|c|c|c|c|c|c|c|c|c|c|c|c|c|c|c|c|c|c|c|c|c|c|c|c|c|c|}
\hline हूँ & 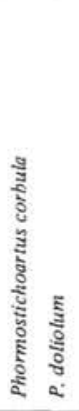 & $\frac{\Xi}{2}$ & 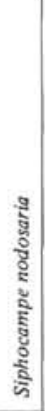 & 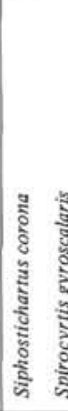 & 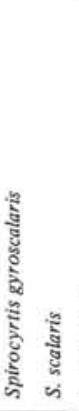 & $\begin{array}{l} \\
\text { हैँ } \\
\text { हैँ } \\
\text { हैं } \\
\text { जे }\end{array}$ & 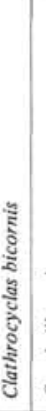 & : & 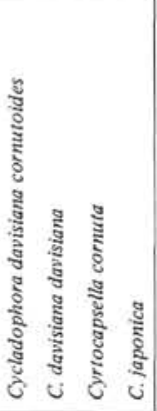 & ปั้ & 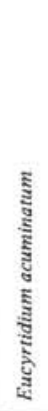 & 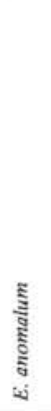 & 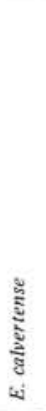 & 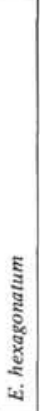 & 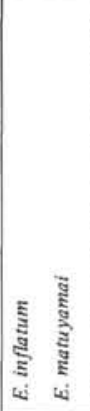 & 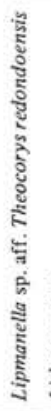 & 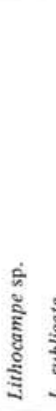 & 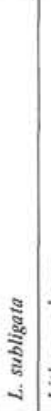 & 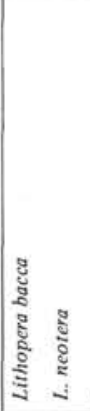 & 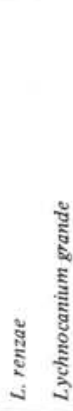 & 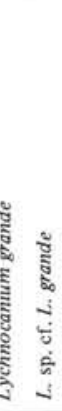 & 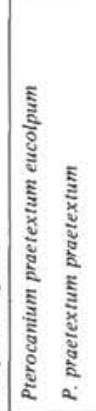 & 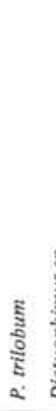 & 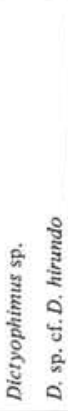 & 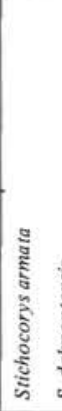 & 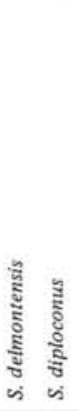 & हैं & 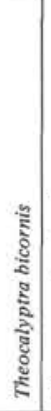 & 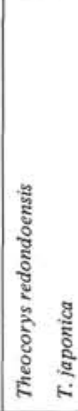 \\
\hline & 1 & $\begin{array}{l}1 \\
1 \\
2 \\
1\end{array}$ & $\begin{array}{l}1 \\
1 \\
1 \\
1 \\
1 \\
\end{array}$ & & $\begin{array}{l}1 \\
1 \\
1 \\
\end{array}$ & $\begin{array}{l}1 \\
1 \\
1 \\
1 \\
1 \\
\end{array}$ & \begin{tabular}{l|l}
1 & \\
1 \\
1 \\
1 \\
1 \\
1
\end{tabular} & $\begin{array}{l}2 \\
2 \\
1 \\
2 \\
2 \\
\end{array}$ & & & $\begin{array}{l}1 \\
1 \\
1 \\
1\end{array}$ & & & & & $\begin{array}{l}1 \\
1 \\
1 \\
1 \\
1\end{array}$ & $\begin{array}{l}1 \\
1 \\
1 \\
1 \\
1\end{array}$ & $\begin{array}{l}2 \\
1 \\
1 \\
1 \\
1\end{array}$ & & & & & & $\begin{array}{l}1 \\
1\end{array}$ & & $\begin{array}{l}1 \\
1 \\
1 \\
1 \\
1 \\
\end{array}$ & $\begin{array}{l}2 \\
1 \\
1 \\
2 \\
2 \\
\end{array}$ & $\begin{array}{l}2 \\
2 \\
1 \\
2 \\
1\end{array}$ & $\begin{array}{l}1 \\
1 \\
1 \\
1\end{array}$ \\
\hline & & $\begin{array}{l}1 \\
1\end{array}$ & $\begin{array}{l}1 \\
1 \\
1 \\
1 \\
1 \\
\end{array}$ & & 1 & $\begin{array}{l}1 \\
1 \\
1 \\
1 \\
\end{array}$ & $\begin{array}{l}1 \\
1 \\
1 \\
1 \\
1 \\
\end{array}$ & $\begin{array}{l}2 \\
2 \\
2 \\
2 \\
1 \\
\end{array}$ & & & $\begin{array}{l}1 \\
1 \\
1 \\
1 \\
1 \\
\end{array}$ & & 1 & & & $\begin{array}{l}1 \\
1 \\
\end{array}$ & $\begin{array}{l}1 \\
1 \\
1 \\
1 \\
\end{array}$ & $\begin{array}{l}1 \\
1 \\
1 \\
1 \\
1 \\
\end{array}$ & & & & & & 1 & & $\begin{array}{l}1 \\
1 \\
1\end{array}$ & $\begin{array}{l}2 \\
2 \\
2 \\
2 \\
2 \\
\end{array}$ & \begin{tabular}{l|l}
1 & \\
1 & \\
1 & \\
2 & \\
2 & \\
\end{tabular} & \begin{tabular}{|l|}
1 \\
1 \\
1 \\
1 \\
1 \\
\end{tabular} \\
\hline & 1 & $\begin{array}{l}1 \\
1 \\
1\end{array}$ & $\begin{array}{l}1 \\
1 \\
1 \\
1 \\
2 \\
\end{array}$ & & & $\begin{array}{l}1 \\
1 \\
1\end{array}$ & $\begin{array}{l}1 \\
1 \\
1 \\
1 \\
1\end{array}$ & $\begin{array}{l}2 \\
2 \\
2 \\
1 \\
1 \\
\end{array}$ & & & 1 & 1 & $\begin{array}{l}1 \\
1\end{array}$ & 1 & & $\begin{array}{l}1 \\
1\end{array}$ & $\begin{array}{l}1 \\
1 \\
1 \\
1\end{array}$ & $\begin{array}{l}2 \\
1 \\
1 \\
2\end{array}$ & 1 & & & & $i$ & & & $\begin{array}{l}1 \\
1 \\
1 \\
1 \\
1\end{array}$ & $\begin{array}{l}2 \\
2 \\
3 \\
3 \\
2 \\
\end{array}$ & \begin{tabular}{l|}
1 \\
1 \\
2 \\
1 \\
2
\end{tabular} & $\begin{array}{l}1 \\
1\end{array}$ \\
\hline & $\begin{array}{l}1 \\
1\end{array}$ & 1 & $\begin{array}{l}2 \\
1 \\
1 \\
1 \\
1\end{array}$ & & & & $\begin{array}{l}1 \\
1 \\
1 \\
1 \\
1\end{array}$ & $\begin{array}{l}2 \\
1 \\
1 \\
1 \\
1\end{array}$ & & & $\begin{array}{l}1 \\
1 \\
1\end{array}$ & & 1 & $\begin{array}{l}1 \\
1\end{array}$ & & 1 & $\begin{array}{l}1 \\
1 \\
1 \\
1 \\
1\end{array}$ & $\begin{array}{l}1 \\
1 \\
1 \\
2 \\
1\end{array}$ & 1 & & & & & & & $\begin{array}{l}1 \\
1 \\
1 \\
2 \\
1\end{array}$ & $\begin{array}{l}3 \\
2 \\
3 \\
4 \\
3\end{array}$ & $\begin{array}{l}1 \\
1 \\
1 \\
1 \\
1\end{array}$ & $\begin{array}{l}1 \\
1 \\
1 \\
1 \\
1\end{array}$ \\
\hline & 1 & $\begin{array}{l}1 \\
1 \\
1\end{array}$ & $\begin{array}{l}1 \\
1 \\
1 \\
\end{array}$ & & & 1 & $\begin{array}{l}1 \\
1 \\
1 \\
1\end{array}$ & $\begin{array}{l}1 \\
1 \\
1 \\
2 \\
2 \\
\end{array}$ & & & $\begin{array}{l}1 \\
1 \\
1 \\
1\end{array}$ & & & & & 1 & $\begin{array}{l}1 \\
1 \\
1 \\
1 \\
1 \\
\end{array}$ & \begin{tabular}{l|l}
1 & \\
1 & \\
1 &
\end{tabular} & & 1 & 1 & & 1 & & & $\begin{array}{l}1 \\
1 \\
1\end{array}$ & $\begin{array}{l}2 \\
2 \\
2 \\
2 \\
3 \\
\end{array}$ & \begin{tabular}{l|}
1 \\
1 \\
1 \\
1 \\
1 \\
\end{tabular} & $\begin{array}{l}1 \\
1 \\
1 \\
1 \\
\end{array}$ \\
\hline & 1 & $\begin{array}{l}1 \\
1\end{array}$ & $\begin{array}{l}1 \\
1 \\
1 \\
1 \\
1\end{array}$ & & & $\begin{array}{l}1 \\
1\end{array}$ & $\begin{array}{l}1 \\
1 \\
1 \\
1 \\
1\end{array}$ & $\begin{array}{l}1 \\
1 \\
1 \\
1 \\
2\end{array}$ & & & $\begin{array}{l}1 \\
1\end{array}$ & 1 & 1 & & • & $\begin{array}{l}1 \\
1 \\
1\end{array}$ & $\begin{array}{l}1 \\
1 \\
1 \\
1 \\
1\end{array}$ & $\begin{array}{l}1 \\
2 \\
1 \\
1 \\
1\end{array}$ & & 1 & I & & & & & $\begin{array}{l}1 \\
1 \\
1 \\
1 \\
1\end{array}$ & $\begin{array}{l}4 \\
3 \\
2 \\
2 \\
2 \\
\end{array}$ & $\begin{array}{l}1 \\
1 \\
1 \\
1 \\
\end{array}$ & $\begin{array}{l}1 \\
1 \\
1 \\
1 \\
\end{array}$ \\
\hline & & $\begin{array}{l}1 \\
1 \\
1\end{array}$ & $\begin{array}{l}2 \\
1 \\
1 \\
1 \\
1 \\
\end{array}$ & & 1 & 1 & $\begin{array}{l}1 \\
1 \\
1 \\
1 \\
1\end{array}$ & $\begin{array}{l}1 \\
1 \\
1 \\
1 \\
1\end{array}$ & - & & $\begin{array}{l}1 \\
1 \\
1\end{array}$ & & 1 & & $\bullet$ & 1 & $\begin{array}{ll}1 & \\
1 \\
1 \\
1 \\
1 \\
1\end{array}$ & $\begin{array}{l}1 \\
1 \\
1 \\
1 \\
1\end{array}$ & & $\begin{array}{l}1 \\
1 \\
2 \\
1\end{array}$ & $\begin{array}{l}1 \\
1 \\
2 \\
1\end{array}$ & $\begin{array}{l}1 \\
1\end{array}$ & & & & $\begin{array}{l}1 \\
1 \\
1 \\
1 \\
1\end{array}$ & $\begin{array}{l}2 \\
2 \\
2 \\
3 \\
2 \\
\end{array}$ & \begin{tabular}{l|}
1 \\
1 \\
1 \\
1 \\
1 \\
\end{tabular} & $\begin{array}{l}1 \\
1 \\
1 \\
\end{array}$ \\
\hline & & $\begin{array}{l}1 \\
1 \\
1\end{array}$ & $\begin{array}{l}1 \\
1 \\
2 \\
1 \\
1\end{array}$ & & & & \begin{tabular}{l|l}
1 & \\
1 \\
1 \\
1 \\
1
\end{tabular} & $\begin{array}{l}1 \\
1 \\
2 \\
2 \\
1\end{array}$ & t & & $\frac{1}{1}$ & & ${ }_{1}^{1}$ & 1 & • & & $\begin{array}{l}1 \\
1 \\
1\end{array}$ & $\begin{array}{l}1 \\
1 \\
1 \\
1\end{array}$ & & $\begin{array}{l}1 \\
2 \\
1\end{array}$ & $\begin{array}{l}1 \\
2 \\
1\end{array}$ & 1 & & & & $\begin{array}{l}1 \\
1 \\
2 \\
2 \\
1\end{array}$ & $\begin{array}{l}1 \\
1 \\
4 \\
1 \\
1\end{array}$ & \begin{tabular}{l|l} 
\\
2 \\
1 \\
1 \\
1 \\
\end{tabular} & $\begin{array}{l}1 \\
2 \\
1 \\
1\end{array}$ \\
\hline & & & $\begin{array}{l}2 \\
1 \\
1\end{array}$ & 1 & 1 & $\begin{array}{l}1 \\
1\end{array}$ & $\begin{array}{l}1 \\
1 \\
1 \\
1\end{array}$ & $\begin{array}{l}2 \\
1 \\
2 \\
2\end{array}$ & & & $\begin{array}{l}1 \\
1\end{array}$ & & $\begin{array}{l}1 \\
1\end{array}$ & & & & $\begin{array}{l}1 \\
1\end{array}$ & $\begin{array}{l}1 \\
1 \\
1 \\
1\end{array}$ & 1 & & & & & & & $\begin{array}{l}2 \\
3 \\
1\end{array}$ & $\begin{array}{l}2 \\
2 \\
1\end{array}$ & $\begin{array}{l}2 \\
1 \\
1 \\
1\end{array}$ & $\begin{array}{l}1 \\
1 \\
1\end{array}$ \\
\hline & 1 & 1 & $\begin{array}{l}1 \\
1 \\
1\end{array}$ & & & 1 & $\begin{array}{l}1 \\
1 \\
1 \\
1\end{array}$ & $\begin{array}{l}2 \\
2 \\
1 \\
1 \\
1\end{array}$ & & & & & 1 & & & & & 1 & & 1 & 1 & & & & & & 1 & $\begin{array}{l}1 \\
2 \\
2 \\
1 \\
1\end{array}$ & $\begin{array}{l}1 \\
1\end{array}$ \\
\hline 1 & $\begin{array}{l}1 \\
1\end{array}$ & $\begin{array}{l}1 \\
1\end{array}$ & $\begin{array}{l}1 \\
1\end{array}$ & 1 & & 1 & $\begin{array}{l}1 \\
1 \\
1 \\
1 \\
\end{array}$ & $\begin{array}{l}1 \\
2 \\
1 \\
2 \\
1\end{array}$ & & & $\begin{array}{l}1 \\
1 \\
1\end{array}$ & & & 1 & & & $\begin{array}{l}1 \\
1\end{array}$ & $\begin{array}{l}1 \\
1\end{array}$ & 1 & & & & & & & $\begin{array}{l}1 \\
1\end{array}$ & & $\begin{array}{l}1 \\
1 \\
1 \\
2 \\
1\end{array}$ & $\begin{array}{l}1 \\
1 \\
1\end{array}$ \\
\hline & $\begin{array}{l}1 \\
1 \\
\end{array}$ & $\begin{array}{l}1 \\
1 \\
1 \\
\end{array}$ & $\begin{array}{l}1 \\
1 \\
1 \\
1 \\
\end{array}$ & & & & $\begin{array}{l}1 \\
1 \\
1 \\
1 \\
\end{array}$ & $\begin{array}{l}1 \\
1 \\
1 \\
1 \\
1 \\
\end{array}$ & & & & 1 & 1 & & & & 1 & 1 & & & & & & & & $\begin{array}{l}1 \\
1 \\
1 \\
1 \\
\end{array}$ & : & $\begin{array}{l}2 \\
2 \\
1 \\
1 \\
\end{array}$ & $\begin{array}{l}1 \\
1 \\
1\end{array}$ \\
\hline & 1 & 1 & $\begin{array}{l}1 \\
1 \\
1 \\
1 \\
1\end{array}$ & & • & 1 & $\begin{array}{l}1 \\
1\end{array}$ & $\begin{array}{l}1 \\
1 \\
1 \\
1 \\
1\end{array}$ & & & 1 & & $\begin{array}{l}1 \\
1\end{array}$ & 1 & & & & $\begin{array}{l}1 \\
1 \\
1\end{array}$ & $\begin{array}{l}1 \\
1 \\
1\end{array}$ & & & 1 & & & & $\begin{array}{l}2 \\
1 \\
2 \\
1\end{array}$ & $\begin{array}{l}1 \\
1 . \\
\vdots\end{array}$ & $\begin{array}{l}1 \\
1 \\
1 \\
1 \\
2\end{array}$ & 1 \\
\hline & 1 & $\begin{array}{l}1 \\
1\end{array}$ & $\begin{array}{l}1 \\
1 \\
2 \\
2\end{array}$ & & & 1 & $\begin{array}{l}1 \\
1 \\
1\end{array}$ & $\begin{array}{l}1 \\
1 \\
1 \\
1\end{array}$ & & & & 1 & 1 & 1 & & & & 1 & $\begin{array}{l}1 \\
1 \\
1\end{array}$ & & & & & 1 & & $\begin{array}{l}1 \\
1 \\
1 \\
1 \\
1\end{array}$ & & \begin{tabular}{l|}
1 \\
1 \\
2 \\
2 \\
1
\end{tabular} & 1 \\
\hline
\end{tabular}


TABLE 2 - Continued

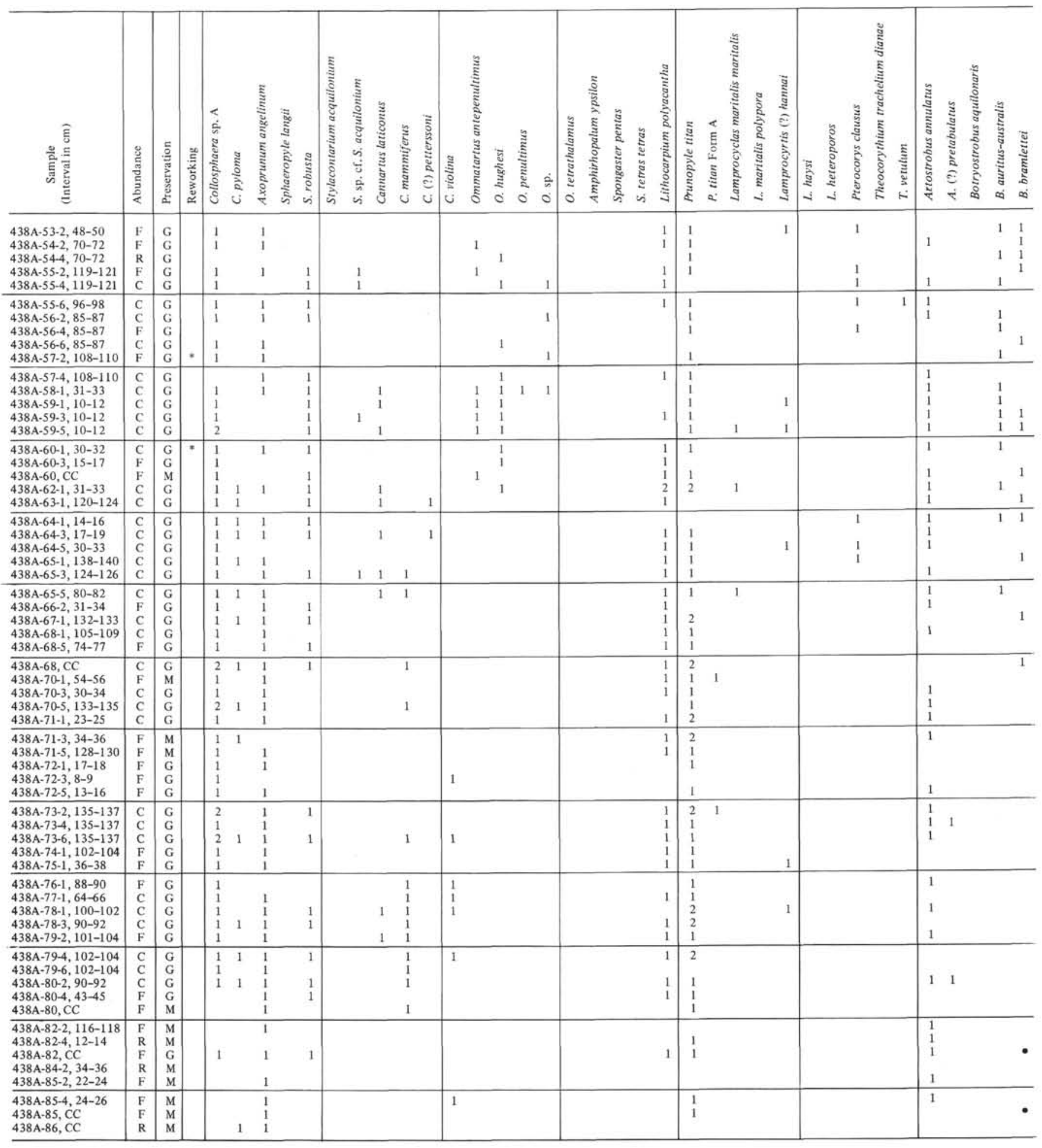


TABLE 2 - Continued

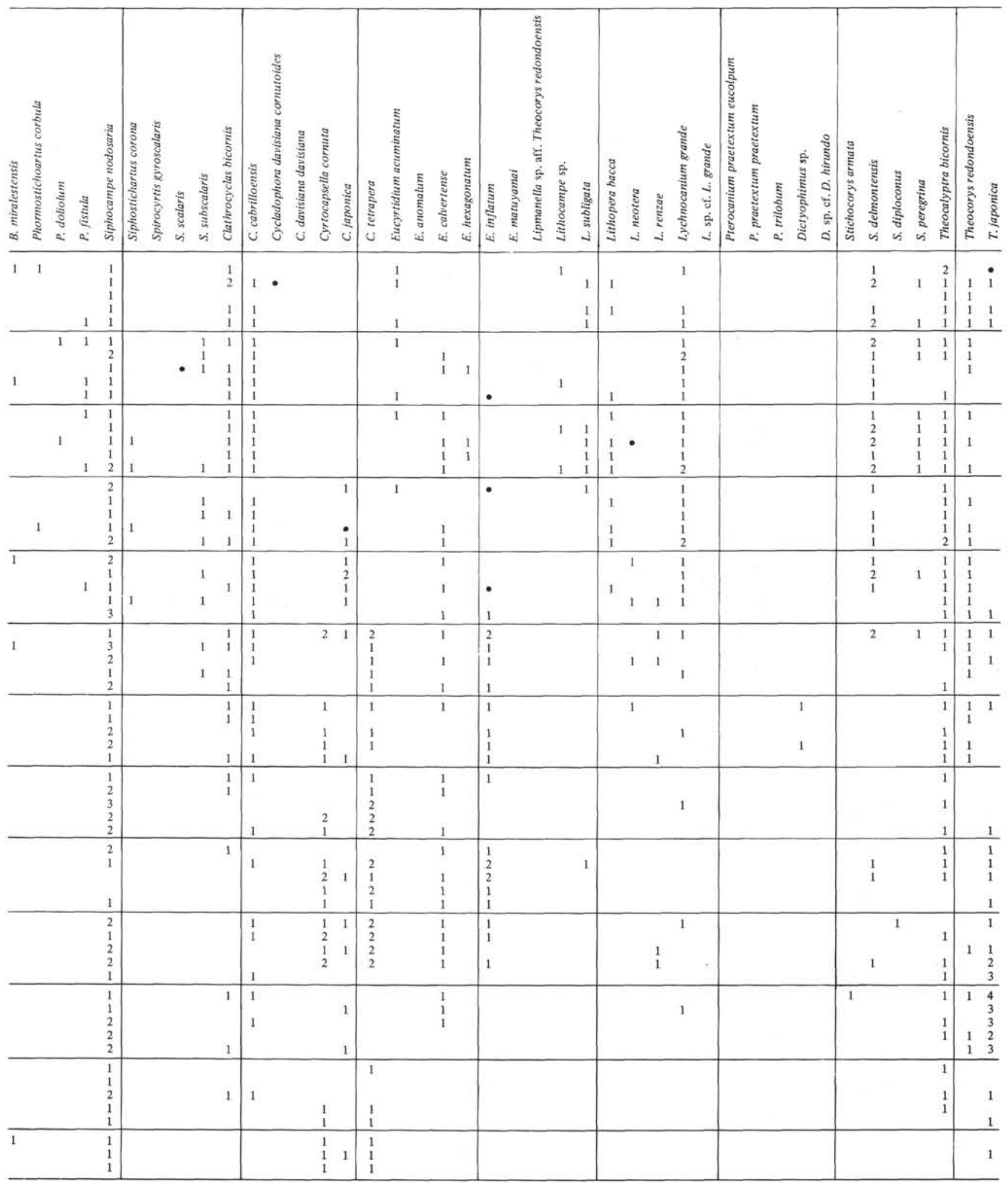


TABLE 3

Abundance/Occurrence Chart, DSDP Hole 438B

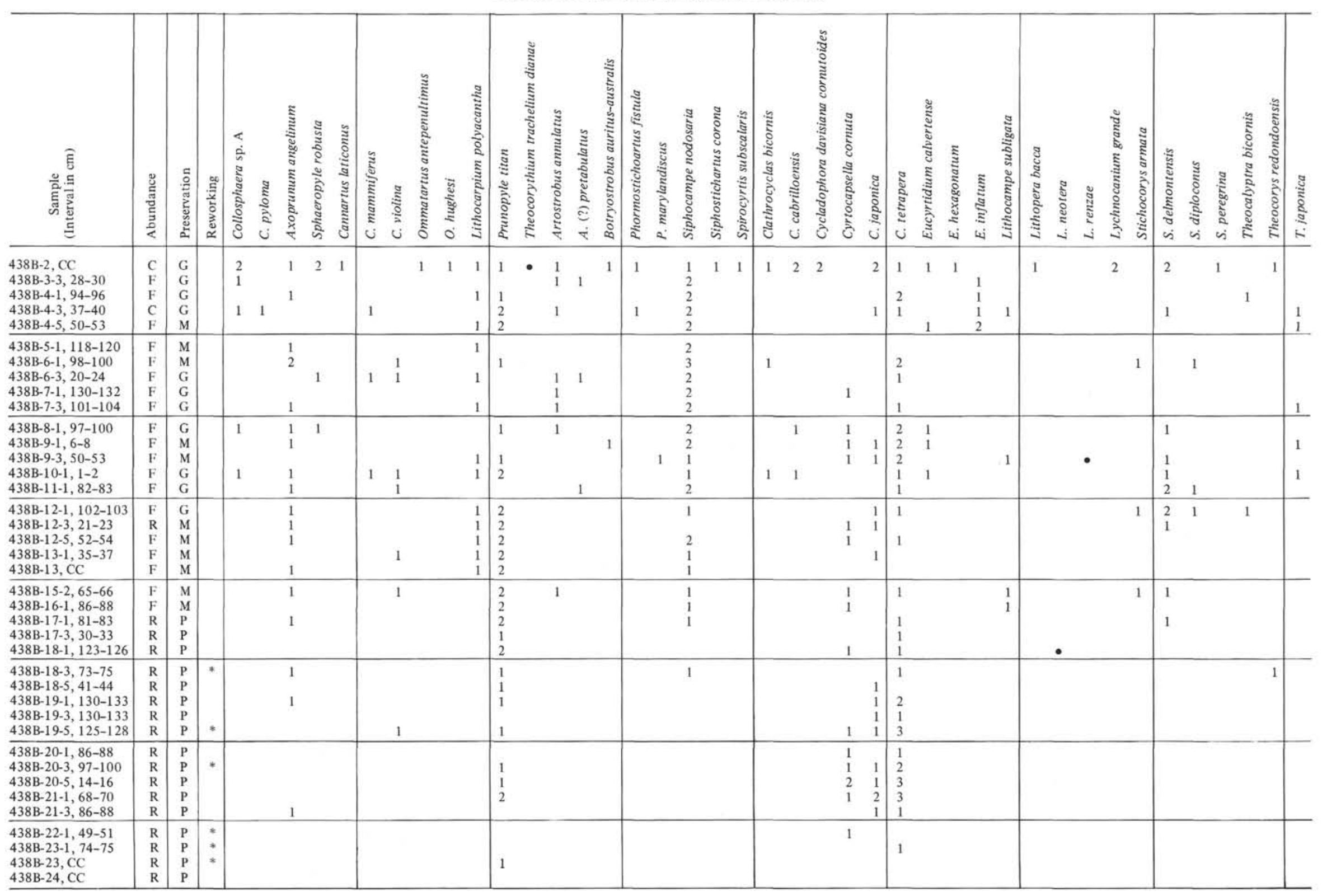


TABLE 4

Abundance/Occurrence Chart, DSDP Hole 439

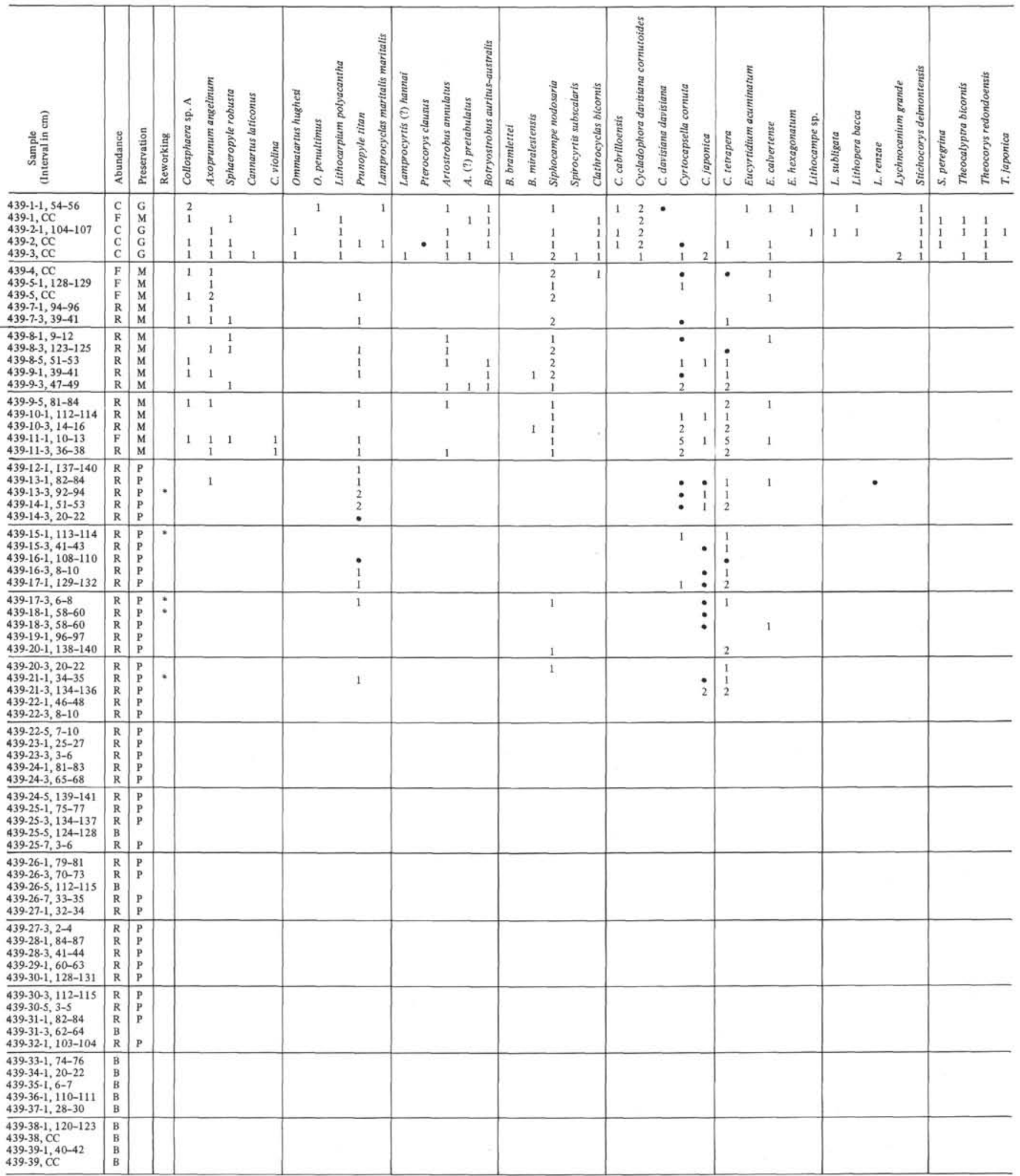


TABLE 5

Abundance/Occurrence Chart, DSDP Hole 440

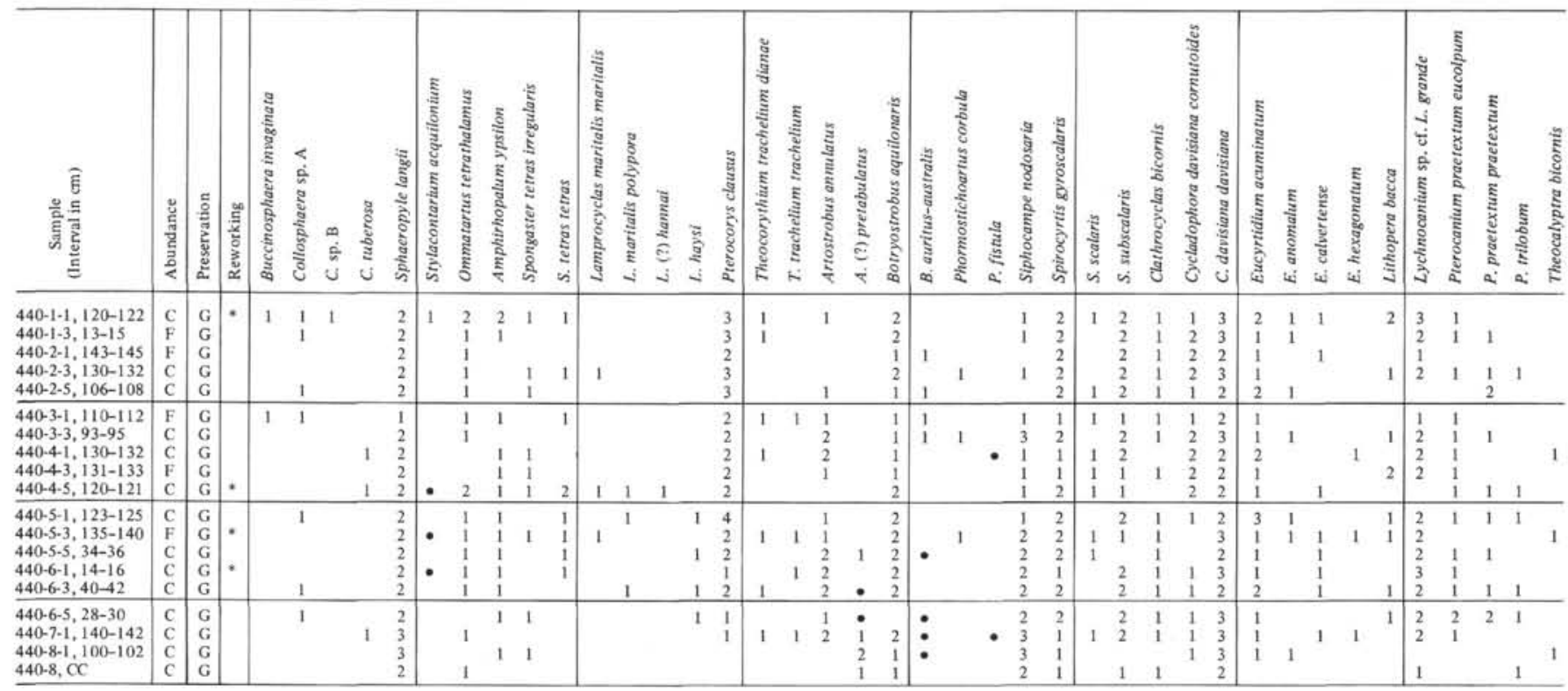

TABLE 6

Abundance/Occurrence Chart, DSDP Hole 440A

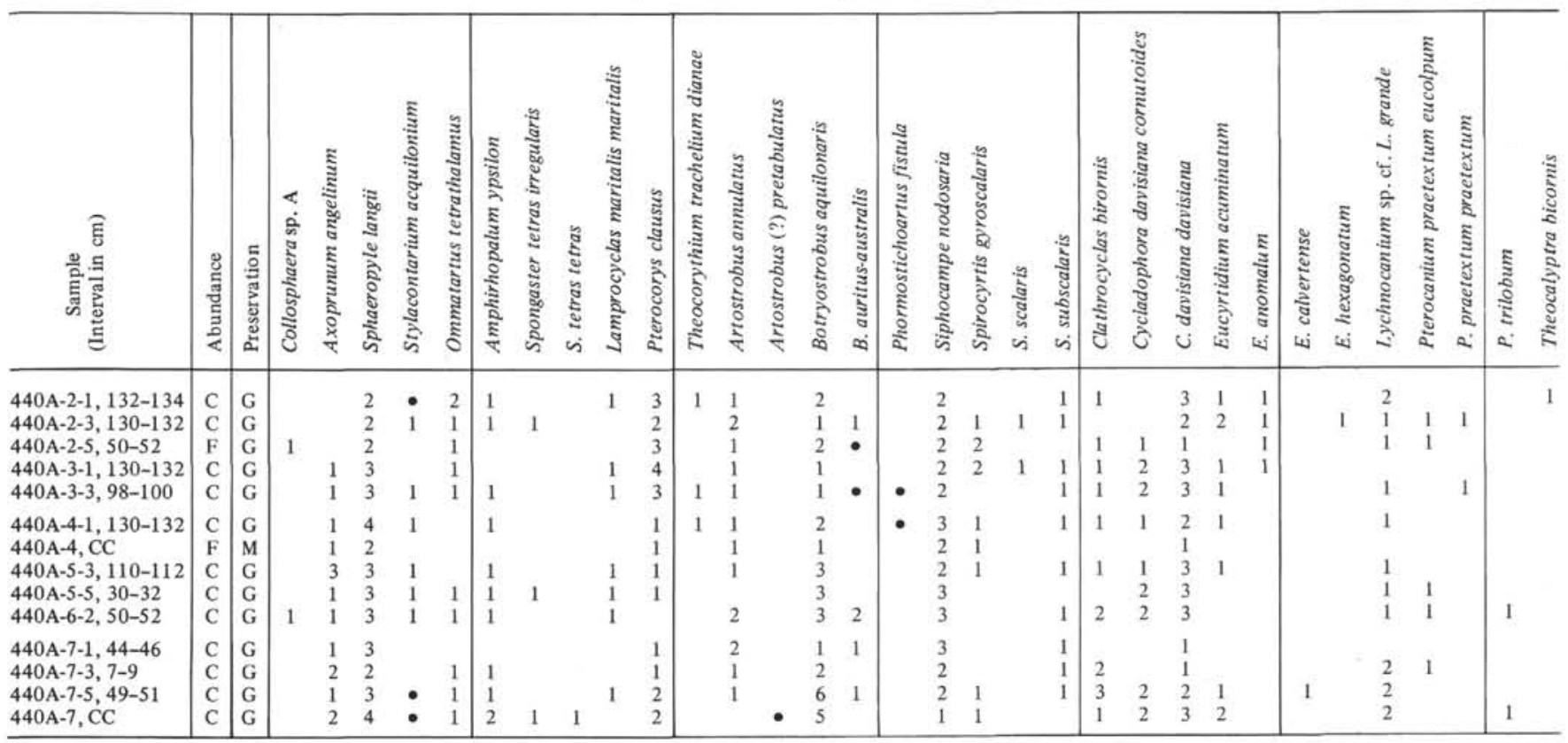

441-2-3-441-2,CC) all contain strata representing this zone. The transition from Sphaeropyle robusta to $S$. langii postdates but nearly coincides with its base.

\section{Lamprocyrtis heteroporos Zone \\ (Hays, 1970 emend. Kling, 1973)}

The base of this zone is defined by the last occurrence of Stichocorys peregrina (2.8 m.y., Hays, 1970). Near the top, which is defined as the transition from Eucyrtidium calvertensis to E. matuyamai, the following important datums may be found: the first appearance of E. matuyamai (1.8 m.y., Kling, 1973) and the coeval last occurrences of Prunopyle titan, Lamprocyrtis heteroporos, and Clathrocyclas cabrilloensis. The L. heteroporos Zone of Hays (1970) correlates in part with this zone. The L. heteroporos Zones of Kling (1973) and Forman (1975) are equivalent to it. The $L$. heteroporos Zone correlates partly with the lower part of the Pterocanium prismatium Zone of Riedel and Sanfilippo (1977). It is Pleistocene at its uppermost level but is predominantly Pliocene in age. Sites 438 (Sections 4385-5-438-12-5 and 438A-5-1-438A-12-1), 440 (Sections 440B-19-5-440B-35-1). and 441 (Sections 441-3, CC441-7-1) possess intervals representative of this zone. 


\section{Sphaeropyle langii Zone (Forman, 1975)}

The base of this zone is defined as the first occurrence of Sphaeropyle langii. The top of this zone and the base of the Lamprocyrtis heteroporos Zone are coincident. Important datums within it are as follows (from top to bottom): The nearly coeval last occurrence of Stichocorys delmontensis and Lithocampe subligata, last occurrence of Lithocampe sp. A, last occurrences of Theocorys redondoensis and Lipmanella sp. aff. $T$. redondoensis, and coeval first occurrence of Lamprocyrtis heteroporos and transition from Stylacontarium sp. cf. $S$. acquilonium to $S$. acquilonium, which is interpreted as the Miocene/Pliocene boundary.

The Sphaeropyle langii Zone of Forman (1975) is equivalent to this zone. Sites 438 (Sections 438-12,CC and 438A-13-1-438A-32-4), 440 (Sections 440B-35-3440B-55-1), and 441 (Sections 441-7,CC-441A-8-1) contain strata typifying it. It is partly equivalent to the Spongaster pentas Zone of Riedel and Sanfilippo (1977).

\section{Theocorys redondoensis Zone (new zone)}

The base of this zone is defined by the transition of Stichocorys peregrina from $S$. delmontensis. The top is the base of the Sphaeropyle langii Zone. Intervals from Sites 438 (Sections 438A-33-2-438A-42-1), 440 (Sections 440B-55-3-440B-63-1), and 441 (Sections 441A-8,CC$441 \mathrm{~B}-2, \mathrm{CC})$ contain sediment representing this zone. The upper Miocene Stichocorys peregrina Zone of Forman (1975) is wholly equivalent to it. The $S$. peregrina Zones of Riedel and Sanfilippo (1977) and Kling (1973) are partially equivalent to it. This is not to imply, however, that the boundaries are time-equivalent. The first occurrence of Lipmanella sp. aff. Theocorys redondoensis occurs within this zone.

\section{Ommatartus penultimus Zone (Riedel and Sanfilippo, 1970)}

The top of this zone is the base of the Theocorys redondoensis Zone and the base is defined as the transition from Ommatartus antepenultimus to $O$. penultimus. This upper Miocene zone is synonymous with the O. penultimus Zones of Riedel and Sanfilippo (1977) and Forman (1975). Auxiliary datums which appear to be nearly coeval with the top of it are the last occurrences of $O$. hughesi, $O$. penultimus and $O$. sp.B. Holes 438A (Sections 438A-42-3-438A-52-6) and 440B (Sections 440B-63-3-440B-71,CC) contain strata representative of this zone.

\section{Ommatartus antepenultimus Zone (Riedel and Sanfilippo, 1977)}

This upper Miocene zone is defined by the range of Ommatartus antepenultimus subsequent to its transition from Cannartus laticonus and prior to its transition to $O$. penultimus. The $O$. antepenultimus Zone of Riedel and Sanfilippo (1977) and Forman (1975) are its equivalent. Representative sediment is recognized in Hole 438A (Sections 438A-53-2-438A-59-5). Important datums occurring at or near the base of this zone are the first appearances of Lithocampe sp. A, O. sp. B, and $O$. penultimus.

\section{Ommatartus hughesi Zone (new zone)}

The base of this zone is defined as the transition from Cannartus petterssoni to Ommatartus hughesi, and the top is the base of the $O$. antepenultimus Zone. The latest occurrence of Collosphaera pyloma is present in the lower part of it. The zone is not reported by Riedel and Sanfilippo, because at lower latitudes the transition from Cannartus petterssoni to $O$. hughesi and $C$. laticonus to $O$. antepenultimus are coeval. Hole 438A contains an interval (Sections 438A-59-5-438-62-1) representing this zone.

\section{Lithopera bacca Zone (new zone)}

The base of this zone is defined by the last occurrence of Eucyrtidium inflatum and the top is equivalent to the base of the Ommatartus hughesi Zone. The Cannartus petterssoni Zone of Riedel and Sanfilippo (1977) correlates with most of the zone. The first occurrence of $C$. petterssoni occurs within the lower part, thus placing it in the middle Miocene. The first appearance of Lithopera bacca occurs at the base of the zone, as does the last occurrence of $L$. renzae and $C$. mammiferus. Hole 438A (Sections 438A-63-1-438A-65-1) contains intervals which are representative of this zone.

\section{Eucyrtidium inflatum Zone (new zone)}

This zone is defined as the range of Eucyrtidium inflatum. Datums occurring within this zone are as follows (from top to bottom): First occurrence of Stichocorys peregrina, first occurrence of Lithopera neotera, coeval first occurrence of Botryostrobus bramlettei and last occurrence of Prunopyle titan form A, last occurrence of Cannartus violina, first occurrence of $P$. titan form A, and first occurrence of $L$. renzae. Strata of Holes 438A (Sections 438A-65-3-438A-78-3) and 438B (Sections 438B-3-3-438B-4-5) are assigned to this zone. The E. inflatum zone correlates in part with the Dorcadospiris alata Zone of Riedel and Sanfilippo (1977). Therefore it is partly middle Miocene.

\section{Sphaeropyle robusta Zone (new zone)}

This zone is defined by the range of Sphaeropyle robusta prior to the first occurrence of Eucyrtidium inflatum. Several datums are nearly coeval with the base of the zone and may be useful in recognizing the base. They are as follows: First appearance of Collosphaera sp. A, Clathrocyclas cabrilloensis, Clathrocyclas bicornis, Cannartus mammiferus, and transition from $C$. violina to $C$. mammiferus. The zone is in part correlative with the Calocycletta costata Zone of Riedel and Sanfilippo (1977), indicating that it is at least in part lower Miocene. Intervals in Holes 438A (Sections 438A79-2-438A-82,CC), 438B (Sections 438B-5-1-438B-10-1) and 439 (Section 439-11-1) are assigned to it.

\section{Lithocarpium polyacantha Zone (new zone)}

This zone is defined by the range of Lithocarpium polyacantha prior to the first occurrence of Sphaeropyle robusta. Two datums are present within it. The uppermost is the first occurrence of Theocalyptra bicornis and the other is the first occurrence of Collosphaera 
TABLE 7

Abundance/Occurrence Chart, DSDP Hole 440B

\begin{tabular}{|c|c|c|c|c|c|c|c|c|c|c|c|c|c|c|c|c|c|c|c|c|c|c|c|c|c|c|c|}
\hline 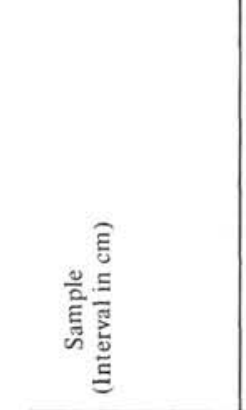 & 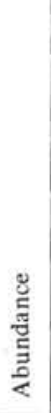 & 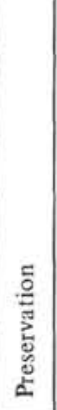 & 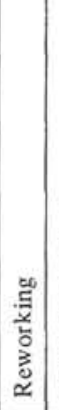 & 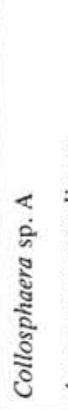 & 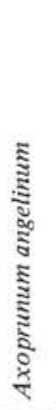 & 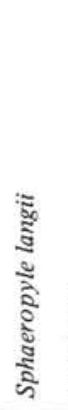 & 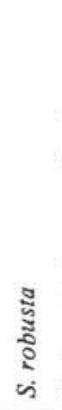 & 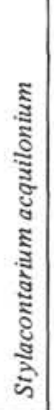 & 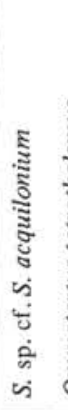 & 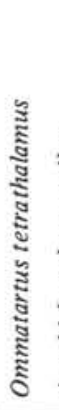 & 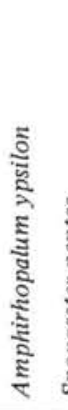 & 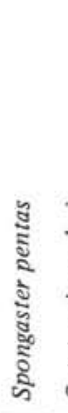 & 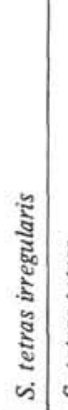 & is & 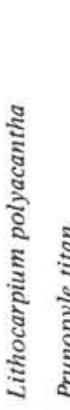 & 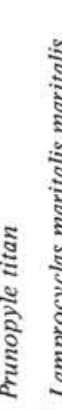 & 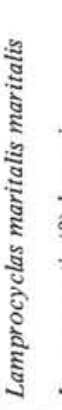 & 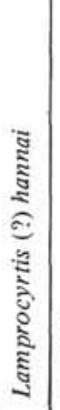 & 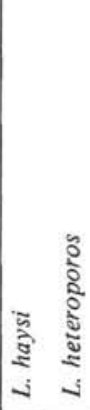 & $\begin{array}{l}\tilde{0} \\
\vdots \\
\vdots \\
\vdots \\
\vdots \\
\vdots \\
\vdots \\
\vdots \\
\vdots \\
\vdots\end{array}$ & : & 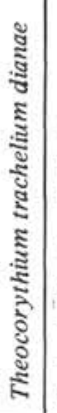 & 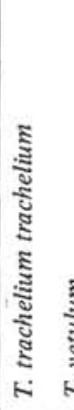 & ב & 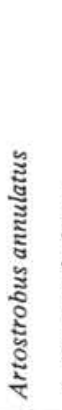 & 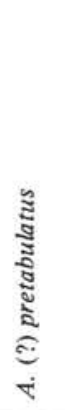 & 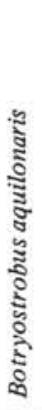 \\
\hline $\begin{array}{l}440 \mathrm{~B}-1-1,1 \mathrm{CO}-102 \\
440 \mathrm{~B}-1, \mathrm{CC} \\
440 \mathrm{~B}-3-1,30-32 \\
440 \mathrm{~B}-3-3,50-52 \\
440 \mathrm{~B}-3-5,26-28\end{array}$ & $\begin{array}{l}\mathrm{C} \\
\mathrm{C} \\
\mathrm{R} \\
\mathrm{C} \\
\mathrm{F}\end{array}$ & $\begin{array}{l}\mathrm{G} \\
\mathrm{G} \\
\mathrm{G} \\
\mathrm{G} \\
\mathrm{M}\end{array}$ & & 1 & 1 & $\begin{array}{l}3 \\
4 \\
1 \\
2 \\
2 \\
\end{array}$ & & 2 & & $\begin{array}{l}2 \\
2 \\
1 \\
1 \\
2 \\
\end{array}$ & $\begin{array}{l}1 \\
2\end{array}$ & & 1 & 1 & & & $\begin{array}{l}1 \\
1\end{array}$ & $\begin{array}{l}1 \\
1\end{array}$ & 1 & & $\begin{array}{l}3 \\
3 \\
1 \\
1 \\
\end{array}$ & 1 & $\begin{array}{l}1 \\
1\end{array}$ & $\begin{array}{l}1 \\
1 \\
\end{array}$ & $\begin{array}{l}1 \\
1 \\
1 \\
1 \\
1\end{array}$ & & $\begin{array}{l}3 \\
1\end{array}$ \\
\hline $\begin{array}{l}440 \mathrm{~B}-4-1,140-142 \\
440 \mathrm{~B}-4-3,45-47 \\
440 \mathrm{~B}-4-5,21-24 \\
440 \mathrm{~B}-5-1,49-52 \\
440 \mathrm{~B}-5-3,36-38\end{array}$ & $\begin{array}{l}\mathrm{C} \\
\mathrm{C} \\
\mathrm{F} \\
\mathrm{F} \\
\mathrm{C}\end{array}$ & $\begin{array}{l}\mathrm{G} \\
\mathrm{G} \\
\mathrm{M} \\
\mathrm{M} \\
\mathrm{G}\end{array}$ & $*$ & $\begin{array}{l}1 \\
1\end{array}$ & $\begin{array}{l}1 \\
2 \\
1 \\
1 \\
1\end{array}$ & $\begin{array}{l}1 \\
2 \\
3 \\
1 \\
3 \\
\end{array}$ & $\begin{array}{l}\cdot \\
1\end{array}$ & $\begin{array}{l}1 \\
1 \\
2 \\
1 \\
1\end{array}$ & & $\begin{array}{l}2 \\
2 \\
2\end{array}$ & $\begin{array}{l}1 \\
1 \\
1 \\
1 \\
1\end{array}$ & & $\begin{array}{l}1 \\
1\end{array}$ & $\begin{array}{l}1 \\
1 \\
1 \\
1\end{array}$ & & • & $\begin{array}{l}1 \\
1\end{array}$ & $\begin{array}{l}1 \\
1 \\
1 \\
1\end{array}$ & & & $\begin{array}{l}2 \\
2\end{array}$ & 1 & & & $\begin{array}{l}1 \\
1 \\
1 \\
1 \\
1\end{array}$ & $\bullet$ & $\begin{array}{l}2 \\
2 \\
2 \\
3 \\
2 \\
\end{array}$ \\
\hline $\begin{array}{l}440 \mathrm{~B}-5-5,40-42 \\
440 \mathrm{~B}-6-1,68-70 \\
440 \mathrm{~B}-6-3,50-52 \\
440 \mathrm{~B}-6-5,22-24 \\
440 \mathrm{~B}-7-1,62-64\end{array}$ & $\begin{array}{l}\mathrm{C} \\
\mathrm{C} \\
\mathrm{C} \\
\mathrm{C} \\
\mathrm{C}\end{array}$ & $\begin{array}{l}\text { G } \\
\text { G } \\
G \\
G \\
G\end{array}$ & $*$ & & $\begin{array}{l}1 \\
1 \\
1 \\
1\end{array}$ & $\begin{array}{l}3 \\
3 \\
3 \\
2 \\
3\end{array}$ & - & $\begin{array}{l}1 \\
1 \\
1\end{array}$ & & $\begin{array}{l}2 \\
1 \\
1 \\
1 \\
1\end{array}$ & $\begin{array}{l}1 \\
1\end{array}$ & & 1 & $\begin{array}{l}1 \\
1 \\
1 \\
1\end{array}$ & & & $\begin{array}{l}1 \\
1 \\
1\end{array}$ & $\begin{array}{l}1 \\
1 \\
1\end{array}$ & & & $\begin{array}{l}1 \\
2 \\
2 \\
2\end{array}$ & 1 & & & $\begin{array}{l}1 \\
1 \\
1\end{array}$ & & $\begin{array}{l}2 \\
2 \\
2 \\
2 \\
3\end{array}$ \\
\hline $\begin{array}{l}440 \mathrm{~B}-7-3,21-23 \\
440 \mathrm{~B}-7-5,20-22 \\
440 \mathrm{~B}-8-1,57-58 \\
440 \mathrm{~B}-8-3,100-102 \\
440 \mathrm{~B}-8-5,81-83\end{array}$ & $\begin{array}{l}\mathrm{C} \\
\mathrm{C} \\
\mathrm{F} \\
\mathrm{F} \\
\mathrm{F}\end{array}$ & $\begin{array}{l}\mathrm{G} \\
\mathrm{G} \\
\mathrm{G} \\
\mathrm{G} \\
\mathrm{G} \\
\end{array}$ & $\begin{array}{l}* \\
*\end{array}$ & & $\begin{array}{l}2 \\
2 \\
1\end{array}$ & $\begin{array}{l}3 \\
3 \\
3 \\
3 \\
3 \\
\end{array}$ & $\begin{array}{l}\bullet \\
\bullet\end{array}$ & $\begin{array}{l}1 \\
3 \\
2 \\
\end{array}$ & & $\begin{array}{l}1 \\
1 \\
1 \\
1\end{array}$ & $\begin{array}{l}1 \\
1\end{array}$ & & & $\begin{array}{l}1 \\
1\end{array}$ & & - & $\begin{array}{l}1 \\
1\end{array}$ & 1 & & 1 & $\begin{array}{l}1 \\
2 \\
1\end{array}$ & & & & $\begin{array}{l}1 \\
1 \\
1\end{array}$ & & $\begin{array}{l}2 \\
1 \\
1 \\
1 \\
\end{array}$ \\
\hline $\begin{array}{l}440 \text { B- } 9-1,27-29 \\
440 B-9-3,7-9 \\
440 B-10-1,145-147 \\
440 B-10-3,33-35 \\
440 B-10-5,35-37\end{array}$ & $\begin{array}{l}\mathrm{F} \\
\mathrm{C} \\
\mathrm{F} \\
\mathrm{F} \\
\mathrm{C}\end{array}$ & $\begin{array}{l}\mathrm{G} \\
\mathrm{G} \\
\mathrm{M} \\
\mathrm{M} \\
\mathrm{G}\end{array}$ & $*$ & & $\begin{array}{l}2 \\
2 \\
1 \\
1\end{array}$ & $\begin{array}{l}2 \\
2 \\
1 \\
2\end{array}$ & • & $\begin{array}{l}1 \\
1\end{array}$ & & $\begin{array}{l}1 \\
1\end{array}$ & $\begin{array}{l}1 \\
1\end{array}$ & 1 & & 1 & & & 1 & 1 & & 1 & $\begin{array}{l}2 \\
1\end{array}$ & & & & $\begin{array}{l}1 \\
1 \\
1 \\
2\end{array}$ & • & $\begin{array}{l}1 \\
1\end{array}$ \\
\hline $\begin{array}{l}440 \mathrm{~B}-10-7,18-20 \\
440 \mathrm{~B}-11-1,137-139 \\
440 \mathrm{~B}-11-3,133-135 \\
440 \mathrm{~B}-11-5,26-28 \\
440 \mathrm{~B}-12-1,114-116\end{array}$ & $\begin{array}{l}\mathrm{C} \\
\mathrm{C} \\
\mathrm{F} \\
\mathrm{F} \\
\mathrm{C}\end{array}$ & $\begin{array}{l}\mathrm{G} \\
\mathrm{G} \\
\mathrm{M} \\
\mathrm{G} \\
\mathrm{G}\end{array}$ & $\begin{array}{l}* \\
* \\
*\end{array}$ & & $\begin{array}{l}3 \\
1 \\
2 \\
2\end{array}$ & $\begin{array}{l}1 \\
1 \\
1\end{array}$ & i & $\begin{array}{l}2 \\
2 \\
3 \\
2 \\
1\end{array}$ & & $\begin{array}{l}1 \\
1\end{array}$ & 1 & & & $\begin{array}{l}2 \\
1\end{array}$ & & & 2 & 1 & & & $\begin{array}{l}1 \\
1\end{array}$ & & & & $\begin{array}{l}1 \\
1\end{array}$ & & $\begin{array}{l}2 \\
1 \\
1 \\
1 \\
1\end{array}$ \\
\hline $\begin{array}{l}40 \mathrm{~B}-12-3,129-131 \\
440 \mathrm{~B}-12-5,136-138 \\
440 \mathrm{~B}-13-1,95-97 \\
440 \mathrm{~B}-13-3,30-32 \\
440 \mathrm{~B}-14-1,104-106\end{array}$ & $\begin{array}{l}\mathrm{C} \\
\mathrm{C} \\
\mathrm{C} \\
\mathrm{C} \\
\mathrm{F}\end{array}$ & $\begin{array}{l}\mathrm{G} \\
\mathrm{G} \\
\mathrm{G} \\
\mathrm{G} \\
\mathrm{G} \\
\end{array}$ & $*$ & & $\begin{array}{l}3 \\
3 \\
1 \\
2 \\
2 \\
\end{array}$ & $\begin{array}{l}1 \\
1 \\
1\end{array}$ & • & $\begin{array}{l}1 \\
2\end{array}$ & & $\begin{array}{l}1 \\
1\end{array}$ & $\begin{array}{l}1 \\
1\end{array}$ & & & $\begin{array}{l}1 \\
1 \\
1 \\
1 \\
1\end{array}$ & & & 1 & $\begin{array}{l}1 \\
1\end{array}$ & & & & & & & $\begin{array}{l}1 \\
1 \\
1 \\
2 \\
1\end{array}$ & & $\begin{array}{l}2 \\
1 \\
1 \\
2 \\
1\end{array}$ \\
\hline $\begin{array}{l}440 \mathrm{~B}-14-3,30-32 \\
440 \mathrm{~B}-14-5,30-32 \\
440 \mathrm{~B}-15-1,50-52 \\
440 \mathrm{~B}-15-3,130-132 \\
440 \mathrm{~B}-15-5,22-24\end{array}$ & $\begin{array}{l}\mathrm{C} \\
\mathrm{C} \\
\mathrm{C} \\
\mathrm{C} \\
\mathrm{C}\end{array}$ & $\begin{array}{l}\mathrm{G} \\
\mathrm{G} \\
\mathrm{G} \\
\mathrm{G} \\
\mathrm{G}\end{array}$ & $*$ & 1 & $\begin{array}{l}2 \\
2 \\
3 \\
2 \\
3\end{array}$ & $\begin{array}{l}1 \\
1 \\
1\end{array}$ & $\begin{array}{l}1 \\
1 \\
1 \\
1 \\
1\end{array}$ & $\begin{array}{l}1 \\
1 \\
1\end{array}$ & & $\begin{array}{l}1 \\
1 \\
1\end{array}$ & $\begin{array}{l}1 \\
1 \\
1\end{array}$ & & & 1 & & $\begin{array}{l}1 \\
1\end{array}$ & 1 & & & & & & & 1 & $\begin{array}{l}1 \\
1 \\
1 \\
1 \\
1\end{array}$ & & $\begin{array}{l}2 \\
2 \\
2 \\
1\end{array}$ \\
\hline $\begin{array}{l}440 \text { B- } 15-7,30-32 \\
440 \text { B-16-1, } 46-48 \\
440 \text { B-1 } 6-3,41-44 \\
440 \text { B-16-5, 20-22 } \\
440 \text { B-1 } 17-1,66-68 \\
\end{array}$ & $\begin{array}{l}\mathrm{F} \\
\mathrm{C} \\
\mathrm{C} \\
\mathrm{C} \\
\mathrm{C}\end{array}$ & $\begin{array}{l}\mathrm{G} \\
\mathrm{G} \\
\mathrm{G} \\
\mathrm{G} \\
\mathrm{G} \\
\end{array}$ & $*$ & & $\begin{array}{l}2 \\
3 \\
2 \\
1 \\
2\end{array}$ & $\begin{array}{l}1 \\
1 \\
1 \\
1 \\
1\end{array}$ & $\begin{array}{l}1 \\
1\end{array}$ & $\begin{array}{l}1 \\
1 \\
1 \\
1\end{array}$ & & 1 & $\begin{array}{l}1 \\
1 \\
1 \\
1\end{array}$ & & \begin{tabular}{l|}
1 \\
1 \\
1 \\
\end{tabular} & $\begin{array}{l}1 \\
1 \\
1 \\
\end{array}$ & & 1 & & 1 & & 1 & & & & & $\begin{array}{l}1 \\
1 \\
1 \\
1 \\
1\end{array}$ & & $\begin{array}{l}2 \\
3 \\
1 \\
1\end{array}$ \\
\hline $\begin{array}{l}440 \mathrm{~B}-17-3,102-105 \\
440 \mathrm{~B}-17-5,22-24 \\
440 \mathrm{~B}-18-1,58-60 \\
440 \mathrm{~B}-18-3,30-32 \\
440 \mathrm{~B}-19-1,61-64\end{array}$ & $\begin{array}{l}\mathrm{C} \\
\mathrm{C} \\
\mathrm{C} \\
\mathrm{C} \\
\mathrm{C}\end{array}$ & $\begin{array}{l}G \\
G \\
G \\
G \\
G\end{array}$ & & & $\begin{array}{l}1 \\
1 \\
1 \\
1 \\
1\end{array}$ & $\begin{array}{l}1 \\
1\end{array}$ & $\begin{array}{l}1 \\
1\end{array}$ & $\begin{array}{l}1 \\
1 \\
1 \\
2\end{array}$ & & 1 & $\begin{array}{l}1 \\
1 \\
1 \\
1\end{array}$ & & 1 & $\begin{array}{l}1 \\
1\end{array}$ & $\bullet$ & $\begin{array}{l}1 \\
\dot{1}\end{array}$ & 1 & 1 & & & & & 1 & & $\begin{array}{l}1 \\
1 \\
1 \\
1\end{array}$ & & $\begin{array}{l}1 \\
1\end{array}$ \\
\hline
\end{tabular}


TABLE 7 - Continued

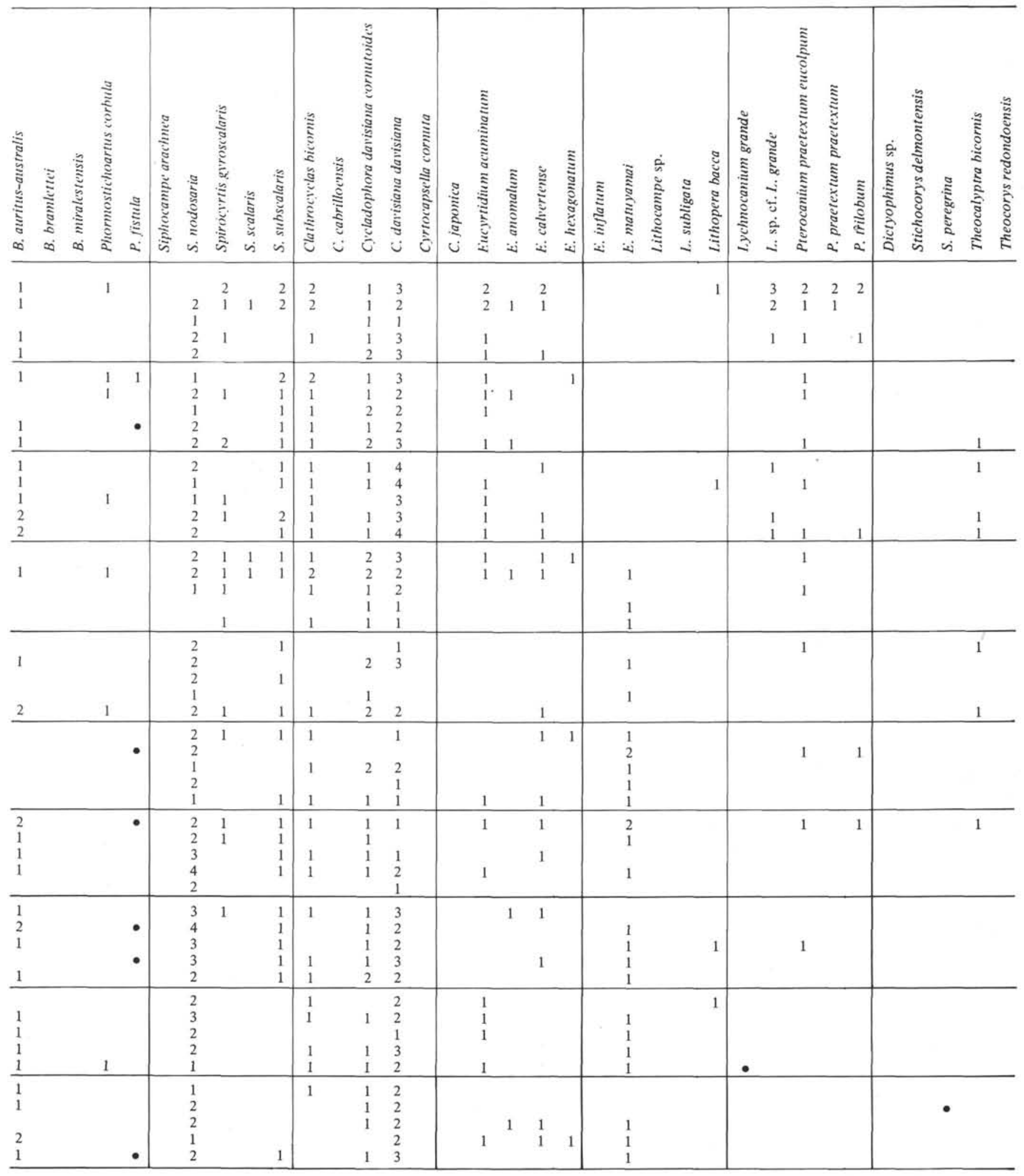


TABLE 7 - Continued

\begin{tabular}{|c|c|c|c|c|c|c|c|c|c|c|c|c|c|c|c|c|c|c|c|c|c|c|c|c|c|}
\hline 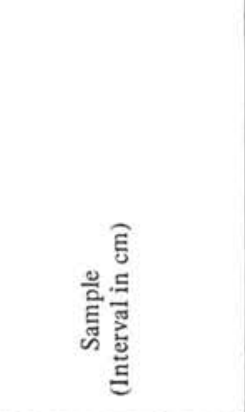 & 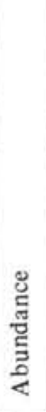 & 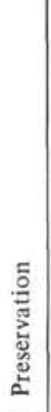 & 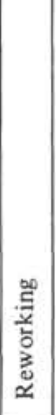 & 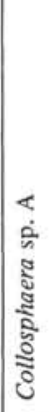 & 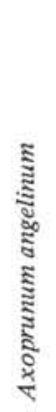 & 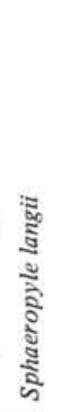 & 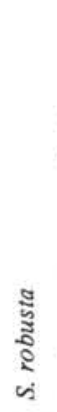 & 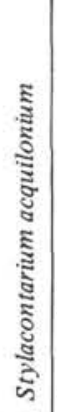 & 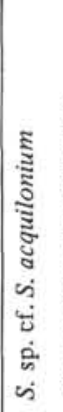 & 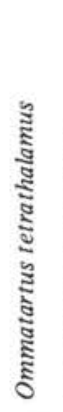 & 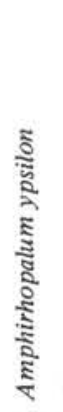 & 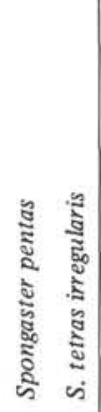 & $\begin{array}{l}\tilde{y} \\
\text { ș } \\
\tilde{y} \\
\text { ș } \\
\dot{v}\end{array}$ & 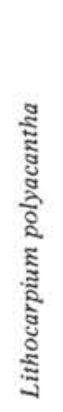 & 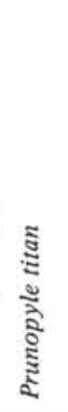 & 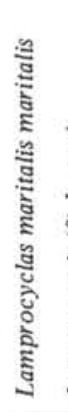 & 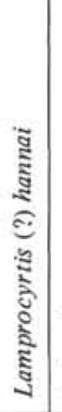 & ב & 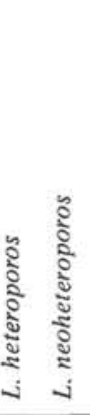 & 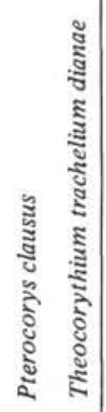 & 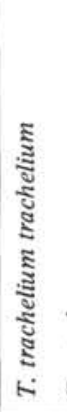 & 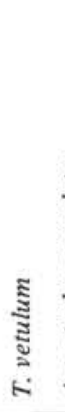 & 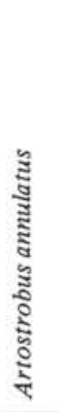 & 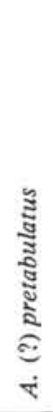 & 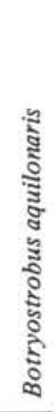 \\
\hline $\begin{array}{l}440 \mathrm{~B}-19-3,12-14 \\
440 \mathrm{~B}-20-1,60-62 \\
440 \mathrm{~B}-20-3,40-42 \\
440 \mathrm{~B}-20-5,35-37 \\
440 \mathrm{~B}-21-1,36-38 \\
\end{array}$ & $\begin{array}{l}\mathrm{C} \\
\mathrm{C} \\
\mathrm{C} \\
\mathrm{C} \\
\mathrm{C}\end{array}$ & $\begin{array}{l}\text { G } \\
G \\
G \\
G \\
G \\
\end{array}$ & & & $\begin{array}{l}2 \\
2 \\
2 \\
1 \\
2\end{array}$ & $\begin{array}{l}1 \\
1 \\
1 \\
1\end{array}$ & $\begin{array}{l}1 \\
1 \\
1 \\
1 \\
1\end{array}$ & $\begin{array}{l}1 \\
1 \\
1 \\
1 \\
1\end{array}$ & & 1 & $\begin{array}{l}1 \\
1 \\
1 \\
1\end{array}$ & 1 & $\begin{array}{l}1 \\
1 \\
1 \\
1 \\
\end{array}$ & $\bullet$ & $\begin{array}{l}1 \\
1 \\
1 \\
1 \\
1\end{array}$ & 1 & & & 1 & & & & $\begin{array}{l}1 \\
2 \\
1 \\
1 \\
1 \\
\end{array}$ & & $\begin{array}{l}1 \\
1 \\
1 \\
1\end{array}$ \\
\hline $\begin{array}{l}440 \mathrm{~B}-21-3,52-54 \\
440 \mathrm{~B}-21-5,44-46 \\
440 \mathrm{~B}-22-1,40-42 \\
440 \mathrm{~B}-22-3,33-35 \\
440 \mathrm{~B}-23-1,59-61 \\
\end{array}$ & $\begin{array}{l}\mathrm{C} \\
\mathrm{F} \\
\mathrm{C} \\
\mathrm{C} \\
\mathrm{C}\end{array}$ & $\begin{array}{l}\mathrm{G} \\
\mathrm{M} \\
\mathrm{M} \\
\mathrm{G} \\
\mathrm{G} \\
\end{array}$ & & & $\begin{array}{l}1 \\
1 \\
2 \\
2 \\
1\end{array}$ & $\begin{array}{l}1 \\
1 \\
1\end{array}$ & $\begin{array}{l}1 \\
1 \\
1\end{array}$ & $\begin{array}{l}1 \\
1 \\
1 \\
1 \\
2\end{array}$ & & & 1 & 1 & $\begin{array}{l}1 \\
1 \\
1\end{array}$ & $\begin{array}{l}1 \\
1 \\
1\end{array}$ & $\begin{array}{l}1 \\
1 \\
1 \\
1\end{array}$ & 1 & & & $\begin{array}{l}1 \\
1 \\
\end{array}$ & & & & $\begin{array}{l}2 \\
1 \\
1 \\
1 \\
1 \\
\end{array}$ & 1 & $\begin{array}{l}1 \\
2 \\
1 \\
1\end{array}$ \\
\hline $\begin{array}{l}440 \mathrm{~B}-23-3,46-48 \\
440 \mathrm{~B}-23-5,27-29 \\
440 \mathrm{~B}-24-1,58-60 \\
440 \mathrm{~B}-24-3,21-23 \\
440 \mathrm{~B}-24-5,130-132 \\
\end{array}$ & $\begin{array}{l}\mathrm{C} \\
\mathrm{C} \\
\mathrm{F} \\
\mathrm{F} \\
\mathrm{C}\end{array}$ & $\begin{array}{l}\mathrm{G} \\
\mathrm{G} \\
\mathrm{G} \\
\mathrm{G} \\
\mathrm{M}\end{array}$ & & & $\begin{array}{l}1 \\
1 \\
1 \\
1 \\
1\end{array}$ & 1 & $\begin{array}{l}1 \\
1\end{array}$ & $\begin{array}{l}1 \\
2 \\
1 \\
1 \\
2\end{array}$ & & 1 & $\begin{array}{l}1 \\
1\end{array}$ & & $\begin{array}{l}1 \\
1 \\
1\end{array}$ & $\begin{array}{l}1 \\
1 \\
1 \\
1\end{array}$ & & 1 & & & $\begin{array}{l}1 \\
1 \\
1 \\
\end{array}$ & & & 1 & $\begin{array}{l}1 \\
1 \\
1 \\
1 \\
1 \\
1\end{array}$ & & \\
\hline $\begin{array}{l}440 \mathrm{~B}-25-1,20-22 \\
440 \mathrm{~B}-26-1,46-47 \\
440 \mathrm{~B}-27-1,40-42 \\
440 \mathrm{~B}-28-1,91-93 \\
440 \mathrm{~B}-28-3,28-30 \\
\end{array}$ & $\begin{array}{l}\mathrm{F} \\
\mathrm{F} \\
\mathrm{C} \\
\mathrm{F} \\
\mathrm{F}\end{array}$ & $\begin{array}{l}\mathrm{G} \\
\mathrm{M} \\
\mathrm{G} \\
\mathrm{G} \\
\mathrm{G} \\
\end{array}$ & $\begin{array}{l}* \\
* \\
* \\
\end{array}$ & & $\begin{array}{l}1 \\
2 \\
1 \\
2 \\
1\end{array}$ & $\begin{array}{l}1 \\
1\end{array}$ & $\begin{array}{l}1 \\
1 \\
1 \\
1 \\
\end{array}$ & $\begin{array}{l}1 \\
1 \\
1 \\
1 \\
1\end{array}$ & & $\begin{array}{l}1 \\
1\end{array}$ & $\begin{array}{l}1 \\
1 \\
1\end{array}$ & & $\begin{array}{l}1 \\
1 \\
1 \\
\end{array}$ & $\begin{array}{l}1 \\
1 \\
1 \\
1\end{array}$ & 1 & 1 & & & 1 & & & & $\begin{array}{l}1 \\
1 \\
1 \\
1 \\
1 \\
1\end{array}$ & & \\
\hline $\begin{array}{l}440 \mathrm{~B}-29-1,48-50 \\
440 \mathrm{~B}-29-3,81-85 \\
440 \mathrm{~B}-30-1,23-25 \\
440 \mathrm{~B}-31-1,117-120 \\
440 \mathrm{~B}-31-3,20-24\end{array}$ & $\begin{array}{l}\mathrm{C} \\
\mathrm{C} \\
\mathrm{F} \\
\mathrm{F} \\
\mathrm{F}\end{array}$ & $\begin{array}{l}\mathrm{G} \\
\mathrm{G} \\
\mathrm{M} \\
\mathrm{M} \\
\mathrm{M}\end{array}$ & * & & $\begin{array}{l}2 \\
2 \\
1 \\
2 \\
2 \\
\end{array}$ & 1 & $\begin{array}{l}1 \\
1 \\
1 \\
1\end{array}$ & $\begin{array}{l}1 \\
1 \\
1 \\
1 \\
1\end{array}$ & & & $\begin{array}{l}1 \\
1\end{array}$ & 1 & 1 & $\begin{array}{l}1 \\
1 \\
1 \\
1\end{array}$ & $\begin{array}{l}1 \\
1 \\
1 \\
1 \\
1\end{array}$ & 1 & 1 & & 1 & & & & $\begin{array}{l}1 \\
1 \\
1 \\
1 \\
1 \\
1\end{array}$ & & 1 \\
\hline $\begin{array}{l}440 \mathrm{~B}-31-5,100-103 \\
440 \mathrm{~B}-32-1,39-42 \\
440 \mathrm{~B}-32-3,7-10 \\
440 \mathrm{~B}-32-5,21-23 \\
440 \mathrm{~B}-33-1,125-128\end{array}$ & $\begin{array}{l}\mathrm{F} \\
\mathrm{F} \\
\mathrm{C} \\
\mathrm{F} \\
\mathrm{C}\end{array}$ & $\begin{array}{l}M \\
G \\
G \\
G \\
G\end{array}$ & * & & $\begin{array}{l}2 \\
1 \\
2 \\
1 \\
2\end{array}$ & 1 & $\begin{array}{l}1 \\
1 \\
\end{array}$ & $\begin{array}{l}1 \\
1 \\
1 \\
1 \\
1\end{array}$ & & & & 1 & $\begin{array}{l}1 \\
1 \\
1\end{array}$ & $\begin{array}{l}1 \\
1 \\
1\end{array}$ & $\begin{array}{l}1 \\
1 \\
1\end{array}$ & 1 & & & & & & & $\begin{array}{l}1 \\
1 \\
1 \\
1 \\
1\end{array}$ & & 1 \\
\hline $\begin{array}{l}440 \mathrm{~B}-33-3,14-16 \\
440 \mathrm{~B}-34-1,90-92 \\
440 \mathrm{~B}-34-3,28-30 \\
440 \mathrm{~B}-35-1,38-40 \\
440 \mathrm{~B}-35-3,20-22 \\
\end{array}$ & $\begin{array}{l}\mathrm{F} \\
\mathrm{F} \\
\mathrm{F} \\
\mathrm{C} \\
\mathrm{C}\end{array}$ & $\begin{array}{l}M \\
P \\
G \\
G \\
G \\
\end{array}$ & $\begin{array}{l}* \\
* \\
* \\
*\end{array}$ & & $\begin{array}{l}1 \\
1 \\
1 \\
1 \\
1\end{array}$ & $\begin{array}{l}1 \\
1 \\
1\end{array}$ & $\begin{array}{l}1 \\
1 \\
1 \\
1 \\
\end{array}$ & $\begin{array}{l}2 \\
1 \\
1 \\
2 \\
1\end{array}$ & & 1 & & & 1 & $\begin{array}{l}1 \\
1 \\
1 \\
2 \\
\end{array}$ & $\begin{array}{l}1 \\
1 \\
1\end{array}$ & & & & & & & 1 & $\begin{array}{l}1 \\
1 \\
1 \\
\end{array}$ & • & \\
\hline $\begin{array}{l}440 \mathrm{~B}-35-5,8-10 \\
440 \mathrm{~B}-36-1,34-36 \\
440 \mathrm{~B}-36-3,1-3 \\
440 \mathrm{~B}-36-5,4-6 \\
440 \mathrm{~B}-37-1,63-65\end{array}$ & $\begin{array}{l}\mathrm{C} \\
\mathrm{C} \\
\mathrm{F} \\
\mathrm{F} \\
\mathrm{C}\end{array}$ & $\begin{array}{l}\mathrm{G} \\
\mathrm{G} \\
\mathrm{M} \\
\mathrm{G} \\
\mathrm{G}\end{array}$ & * & 1 & $\begin{array}{l}1 \\
1 \\
1 \\
1 \\
1\end{array}$ & $\begin{array}{l}1 \\
1 \\
1 \\
1\end{array}$ & $\begin{array}{l}1 \\
1\end{array}$ & $\begin{array}{l}1 \\
1 \\
1 \\
1\end{array}$ & & & & & 1 & $\begin{array}{l}2 \\
1 \\
1 \\
1 \\
1\end{array}$ & $\begin{array}{l}1 \\
1 \\
1 \\
1 \\
2\end{array}$ & $\begin{array}{l}1 \\
1\end{array}$ & & & & & & & $\begin{array}{l}1 \\
1 \\
1 \\
1 \\
1\end{array}$ & • & \\
\hline $\begin{array}{l}440 \mathrm{~B}-37-3,32-34 \\
440 \mathrm{~B}-38-1,70-72 \\
440 \mathrm{~B}-38-3,28-30 \\
440 \mathrm{~B}-39-1,147-149 \\
440 \mathrm{~B}-39-3,88-90\end{array}$ & $\begin{array}{l}\mathrm{F} \\
\mathrm{C} \\
\mathrm{F} \\
\mathrm{F} \\
\mathrm{C}\end{array}$ & $\begin{array}{l}\mathrm{G} \\
\mathrm{G} \\
\mathrm{M} \\
\mathrm{M} \\
\mathrm{G} \\
\end{array}$ & & & $\begin{array}{l}1 \\
1 \\
1 \\
1 \\
2\end{array}$ & $\begin{array}{l}1 \\
1 \\
1 \\
1 \\
1\end{array}$ & $\begin{array}{l}1 \\
1 \\
1 \\
1 \\
2\end{array}$ & $\begin{array}{l}1 \\
1 \\
1 \\
1 \\
1 \\
\end{array}$ & & 1 & - & & $\begin{array}{l}1 \\
1\end{array}$ & $\begin{array}{l}1 \\
1 \\
1 \\
1 \\
1\end{array}$ & $\begin{array}{l}1 \\
1 \\
1 \\
1 \\
1\end{array}$ & & & & & & & & $\begin{array}{l}1 \\
1 \\
1 \\
1 \\
1\end{array}$ & • & 1 \\
\hline $\begin{array}{l}440 \mathrm{~B}-40-1,19-21 \\
440 \mathrm{~B}-40-3,9-11 \\
440 \mathrm{~B}-40-5,15-17 \\
440 \mathrm{~B}-41-1,106-108 \\
440 \mathrm{~B}-42-1,116-118\end{array}$ & $\begin{array}{l}\mathrm{C} \\
\mathrm{C} \\
\mathrm{C} \\
\mathrm{C} \\
\mathrm{F}\end{array}$ & $\begin{array}{l}\mathrm{G} \\
\mathrm{G} \\
\mathrm{G} \\
\mathrm{M} \\
\mathrm{M} \\
\end{array}$ & & 1 & $\begin{array}{l}1 \\
1 \\
1 \\
1 \\
2\end{array}$ & $\begin{array}{l}1 \\
1 \\
1 \\
1\end{array}$ & $\begin{array}{l}1 \\
2 \\
1 \\
1 \\
1 \\
\end{array}$ & $\begin{array}{l}1 \\
1 \\
1 \\
1 \\
1 \\
\end{array}$ & & 1 & & & & $\begin{array}{l}1 \\
1 \\
1 \\
1 \\
1\end{array}$ & $\begin{array}{l}1 \\
1 \\
\end{array}$ & 1 & & & & & & & $\begin{array}{l}1 \\
1 \\
1 \\
1 \\
2\end{array}$ & • & \\
\hline $\begin{array}{l}440 \mathrm{~B}-42-3,120-123 \\
440 \mathrm{~B}-43-1,60-62 \\
440 \mathrm{~B}-43-3,96-98 \\
440 \mathrm{~B}-43, \mathrm{CC} \\
440 \mathrm{~B}-45-1,38-40\end{array}$ & $\begin{array}{l}\mathrm{F} \\
\mathrm{F} \\
\mathrm{F} \\
\mathrm{C} \\
\mathrm{C}\end{array}$ & $\begin{array}{l}\mathrm{M} \\
\mathrm{M} \\
\mathrm{M} \\
\mathrm{M} \\
\mathrm{P}\end{array}$ & * & & $\begin{array}{l}1 \\
2 \\
2 \\
2 \\
2 \\
\end{array}$ & $\begin{array}{l}1 \\
1 \\
1 \\
1\end{array}$ & $\begin{array}{l}1 \\
1 \\
1 \\
1 \\
1 \\
\end{array}$ & $\begin{array}{l}1 \\
1 \\
1 \\
1 \\
1 \\
\end{array}$ & & 1 & & & & $\begin{array}{l}1 \\
1 \\
1\end{array}$ & $\begin{array}{l}1 \\
1 \\
1 \\
1\end{array}$ & $\begin{array}{l}1 \\
1 \\
1 \\
1\end{array}$ & & & & & & & $\begin{array}{l}1 \\
1 \\
1 \\
1 \\
1\end{array}$ & $\bullet$ & \\
\hline
\end{tabular}


TABLE 7 - Continued

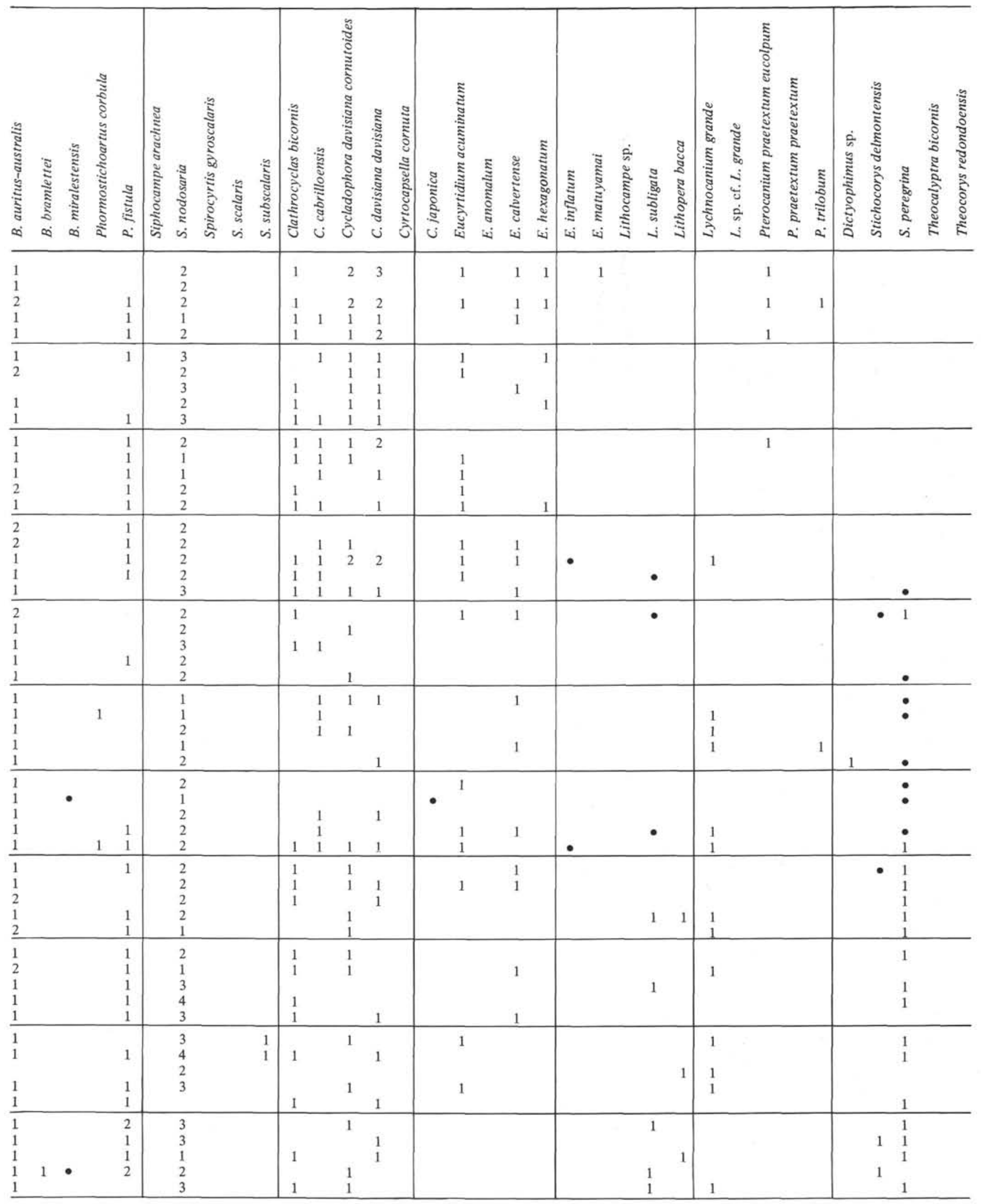


TABLE 7 - Continued

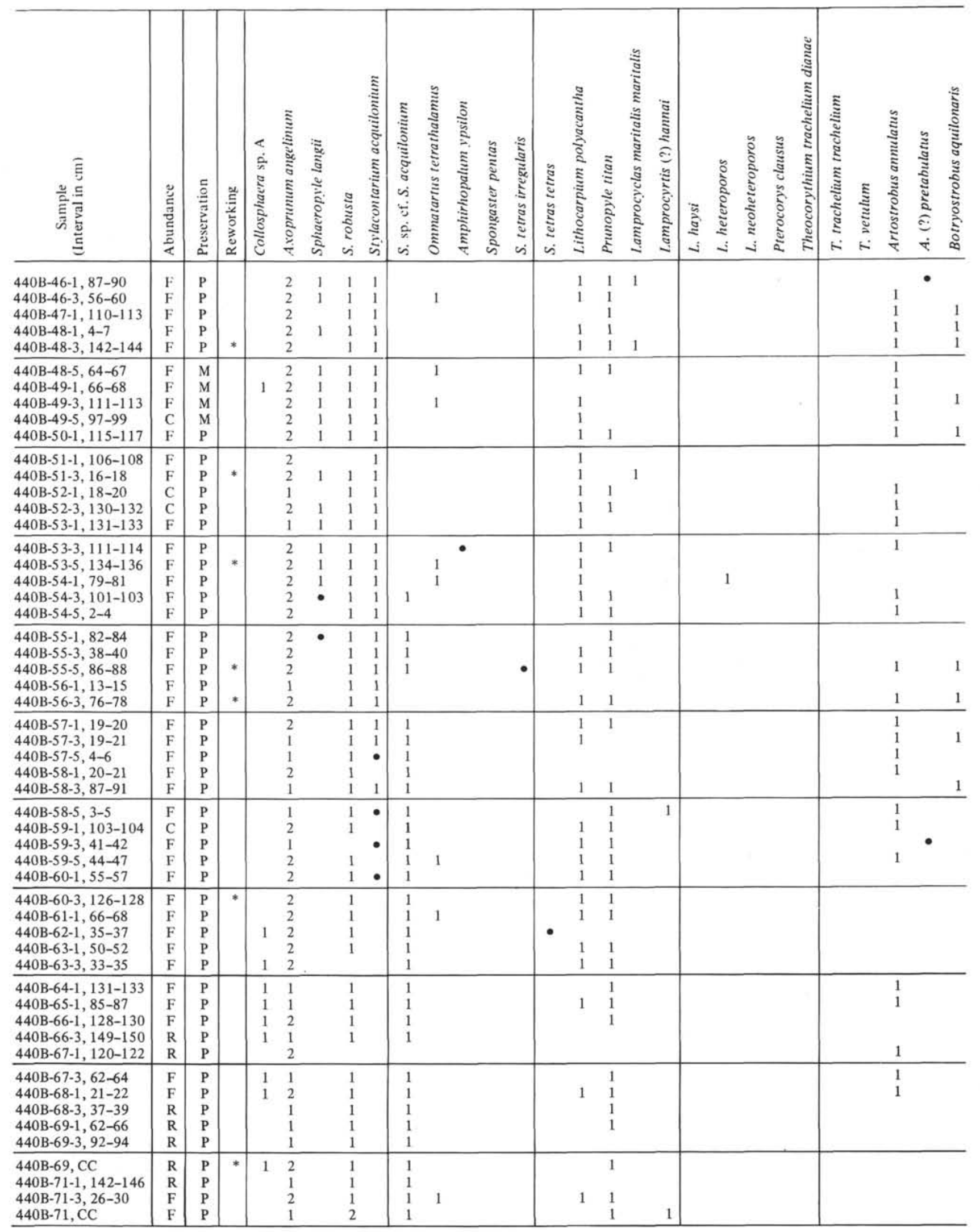


WESTERN NORTH PACIFIC RADIOLARIANS

TABLE 7 - Continued

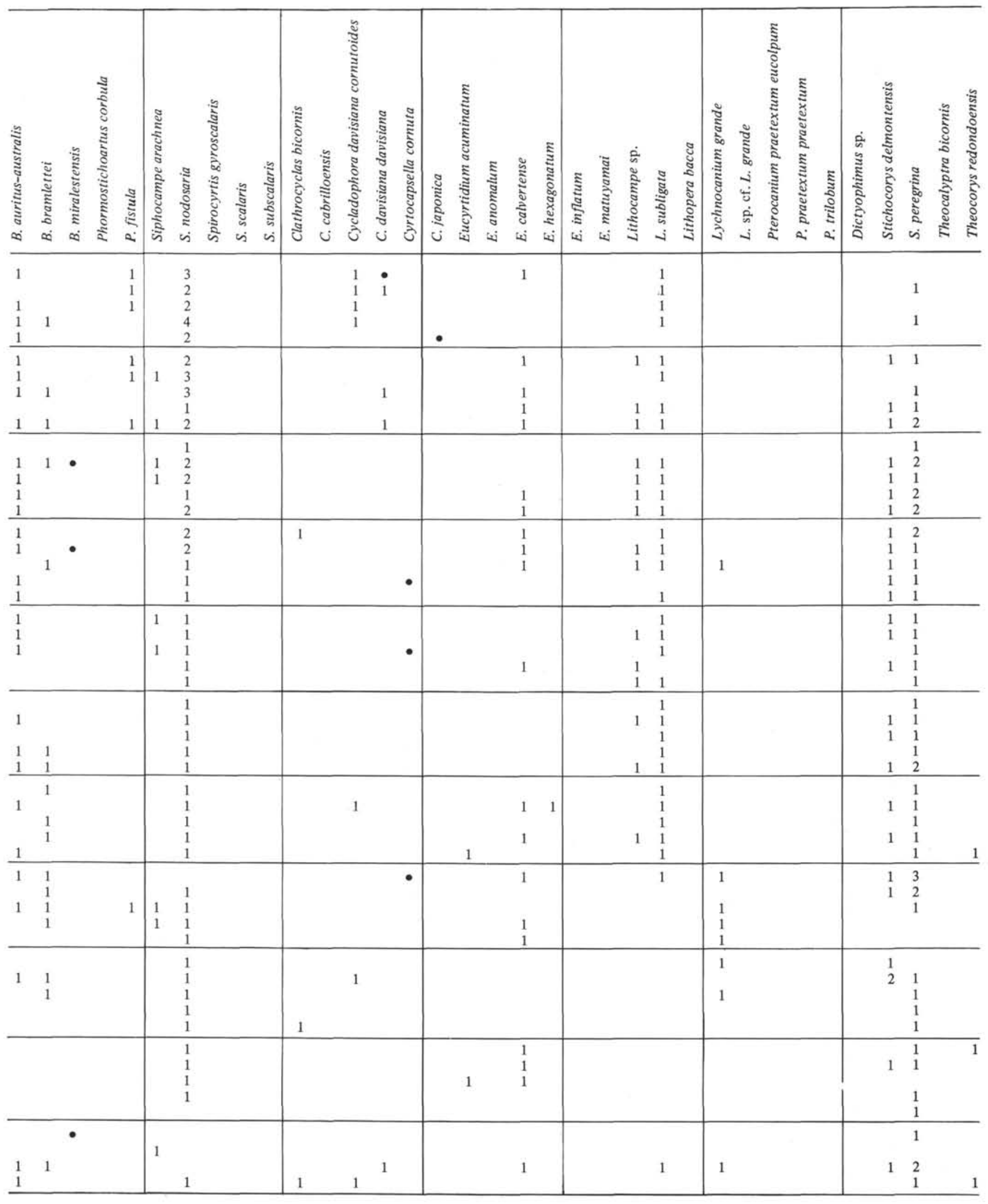

753 
TABLE 8

Abundance/Occurrence Chart, Holes at Site 441

\begin{tabular}{|c|c|c|c|c|c|c|c|c|c|c|c|c|c|c|c|c|c|c|c|c|c|c|c|c|c|c|c|}
\hline 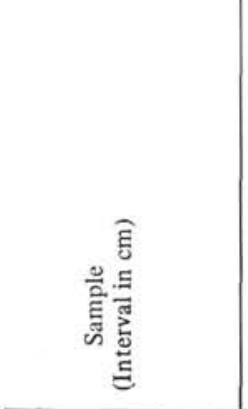 & 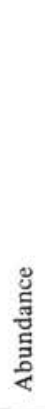 & 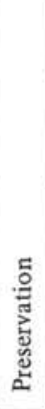 & 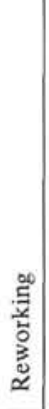 & 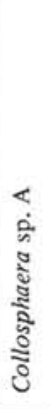 & 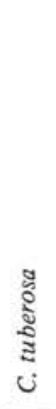 & 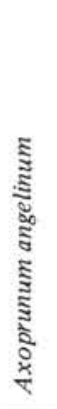 & 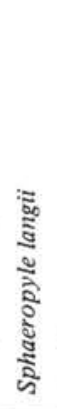 & $\begin{array}{l} \\
\\
\vdots \\
\vdots \\
\vdots \\
\vdots \\
\vdots \\
\vdots\end{array}$ & 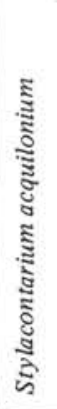 & 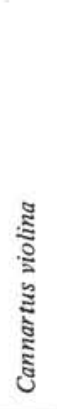 & 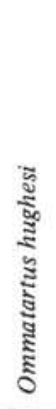 & 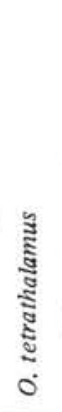 & 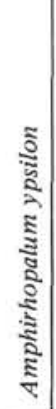 & 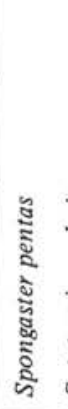 & 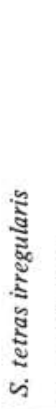 & 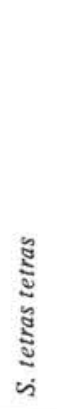 & 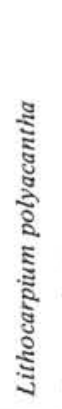 & 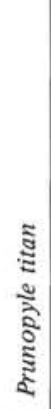 & 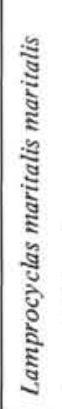 & 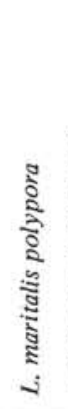 & 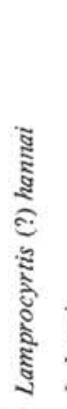 & 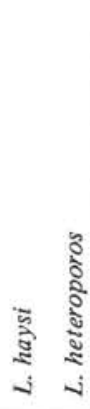 & 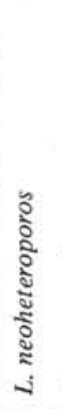 & 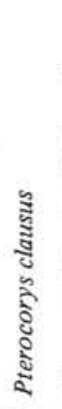 & 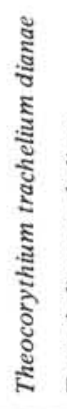 & 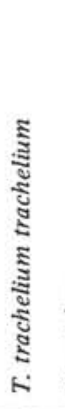 & . \\
\hline $\begin{array}{l}441-1-2,50-52 \\
441-1, \text { CC } \\
441-2-1,49-52 \\
441-2-3,94-96 \\
441-2-5,60-62\end{array}$ & $\begin{array}{l}\mathrm{C} \\
\mathrm{C} \\
\mathrm{C} \\
\mathrm{C} \\
\mathrm{C}\end{array}$ & $\begin{array}{l}\text { G } \\
\text { G } \\
G \\
G \\
G\end{array}$ & $\begin{array}{l}* \\
* \\
* \\
*\end{array}$ & 1 & 1 & $\begin{array}{l}- \\
2 \\
2 \\
3\end{array}$ & $\begin{array}{l}4 \\
4 \\
1 \\
1 \\
1\end{array}$ & • & $\begin{array}{l}\bullet \\
1 \\
1 \\
2\end{array}$ & & & $\begin{array}{l}2 \\
1 \\
2 \\
1\end{array}$ & $\begin{array}{l}1 \\
1 \\
1\end{array}$ & - & $\begin{array}{l}1 \\
1\end{array}$ & $\begin{array}{l}1 \\
1 \\
1\end{array}$ & & & $\begin{array}{l}1 \\
1 \\
1 \\
1\end{array}$ & $\begin{array}{l}1 \\
1\end{array}$ & $\begin{array}{l}2 \\
1\end{array}$ & 1 & & $\begin{array}{l}3 \\
3 \\
3\end{array}$ & $\begin{array}{l}1 \\
1 \\
1 \\
1 \\
\end{array}$ & $\begin{array}{l}\bullet \\
1\end{array}$ & \\
\hline $\begin{array}{l}441-2, \text { CC } \\
441-3, \text { CC } \\
441-4, \text { CC } \\
441-6, C C \\
441-7-1,76-78\end{array}$ & $\begin{array}{l}\mathrm{C} \\
\mathrm{C} \\
\mathrm{C} \\
\mathrm{C} \\
\mathrm{C}\end{array}$ & $\begin{array}{l}\text { G } \\
\text { G } \\
\text { G } \\
\text { G } \\
\text { G }\end{array}$ & $\begin{array}{l}* \\
* \\
*\end{array}$ & 1 & & $\begin{array}{l}2 \\
1 \\
2 \\
1\end{array}$ & $\begin{array}{l}2 \\
1 \\
1 \\
1 \\
1\end{array}$ & $\begin{array}{l}1 \\
1 \\
1 \\
1 \\
1\end{array}$ & $\begin{array}{l}2 \\
1 \\
2 \\
1\end{array}$ & & & $\begin{array}{l}1 \\
1 \\
1\end{array}$ & $\begin{array}{l}2 \\
1 \\
1 \\
1\end{array}$ & & 1 & $\begin{array}{l}1 \\
1\end{array}$ & 1 & $\begin{array}{l}\dot{0} \\
1 \\
1 \\
1\end{array}$ & $\begin{array}{l}1 \\
1 \\
1 \\
1\end{array}$ & & $\begin{array}{l}1 \\
1\end{array}$ & $\begin{array}{l}3 \\
1 \\
1\end{array}$ & $\begin{array}{l}1 \\
1 \\
1\end{array}$ & 1 & & $\begin{array}{l}1 \\
1\end{array}$ & $\begin{array}{l}2 \\
1 \\
1\end{array}$ \\
\hline $\begin{array}{l}441-7, \text { CC } \\
441-8-1,59-61 \\
441-8, \text { CC } \\
441-9-1,56-58 \\
441-9, \text { CC } \\
\end{array}$ & $\begin{array}{l}\text { C } \\
\text { C } \\
\text { F } \\
\text { F } \\
\text { F }\end{array}$ & $\begin{array}{l}\mathrm{G} \\
\mathrm{G} \\
\mathrm{G} \\
\mathrm{G} \\
\mathrm{G}\end{array}$ & & 1 & & $\begin{array}{l}1 \\
1 \\
1 \\
1\end{array}$ & $\begin{array}{l}1 \\
1 \\
1 \\
1 \\
1 \\
\end{array}$ & $\begin{array}{l}2 \\
1 \\
1 \\
1 \\
1 \\
\end{array}$ & $\begin{array}{l}1 \\
1 \\
1\end{array}$ & & & & & & & 1 & $\begin{array}{l}1 \\
1 \\
1\end{array}$ & \begin{tabular}{l|}
1 \\
1 \\
1 \\
1 \\
1 \\
\end{tabular} & & & & & & & & & \\
\hline $\begin{array}{l}441 \mathrm{~A}-2-1,28-30 \\
441 \mathrm{~A}-2, \mathrm{CC} \\
441 \mathrm{~A}-5-1,55-57 \\
441 \mathrm{~A}-5-3,77-79 \\
441 \mathrm{~A}-5, \mathrm{CC}\end{array}$ & $\begin{array}{l}\text { C } \\
\text { C } \\
\text { B } \\
\text { C } \\
\text { F }\end{array}$ & $\begin{array}{l}\text { G } \\
\text { G } \\
\text { G } \\
\text { G }\end{array}$ & $\begin{array}{l}* \\
*\end{array}$ & 1 & & $\begin{array}{l}1 \\
1\end{array}$ & $\begin{array}{l}1 \\
1 \\
1\end{array}$ & $\begin{array}{l}1 \\
1\end{array}$ & $\begin{array}{l}1 \\
1 \\
1\end{array}$ & & & $\begin{array}{l}1 \\
1\end{array}$ & $\begin{array}{l}1 \\
1\end{array}$ & & & & $\begin{array}{l}1 \\
1 \\
1 \\
1\end{array}$ & $\begin{array}{l}1 \\
2 \\
1\end{array}$ & 1 & & & 1 & & & & & \\
\hline $\begin{array}{l}441 \mathrm{~A}-6, \mathrm{CC} \\
441 \mathrm{~A}-8-1,63-65 \\
441 \mathrm{~A}-8, \mathrm{CC} \\
441 \mathrm{~A}-9, \mathrm{CC} \\
441 \mathrm{~A}-10-1,121-123\end{array}$ & $\begin{array}{l}\mathrm{F} \\
\mathrm{F} \\
\mathrm{F} \\
\mathrm{R} \\
\mathrm{R}\end{array}$ & $\begin{array}{l}\mathrm{G} \\
\mathrm{M} \\
\mathrm{M} \\
\mathrm{M} \\
\mathrm{M}\end{array}$ & $\begin{array}{l}* \\
* \\
*\end{array}$ & & & $\begin{array}{l}1 \\
2 \\
2 \\
1 \\
1\end{array}$ & 1 & $\begin{array}{l}1 \\
1\end{array}$ & $\begin{array}{l}1 \\
1\end{array}$ & $\bullet$ & - & & & & & & $\begin{array}{l}1 \\
1\end{array}$ & $\begin{array}{l}1 \\
1\end{array}$ & & & & & & & & & \\
\hline $\begin{array}{l}441 \mathrm{~A}-11-1,83-85 \\
441 \mathrm{~A}-11, \mathrm{CC} \\
441 \mathrm{~A}-12-1,85-88 \\
441 \mathrm{~A}-13-1,70-72 \\
441 \mathrm{~A}-13, \mathrm{CC} \\
\end{array}$ & $\begin{array}{l}\mathrm{R} \\
\mathrm{R} \\
\mathrm{R} \\
\mathrm{B} \\
\mathrm{R}\end{array}$ & $\begin{array}{l}\mathrm{M} \\
\mathrm{M} \\
\mathrm{M} \\
\mathrm{M}\end{array}$ & * & & & 1 & & & & & & & & & & & & 1 & & & & & & & & & \\
\hline $\begin{array}{l}441 \mathrm{~A}-14-1,44-46 \\
441 \mathrm{~A}-15-1,46-48 \\
441 \mathrm{~A}-15, \mathrm{CC} \\
441 \mathrm{~B}-1-1,10-12 \\
441 \mathrm{~B}-1-3,20-22 \\
\end{array}$ & $\begin{array}{l}\mathrm{R} \\
\mathrm{R} \\
\mathrm{R} \\
\mathrm{R} \\
\mathrm{R}\end{array}$ & $\begin{array}{l}\mathrm{M} \\
\mathrm{M} \\
\mathrm{M} \\
\mathrm{G} \\
\mathrm{M}\end{array}$ & * & 1 & & $\begin{array}{l}1 \\
1 \\
1 \\
1 \\
\end{array}$ & $\begin{array}{l}1 \\
1\end{array}$ & $\begin{array}{l}1 \\
1 \\
\end{array}$ & 1 & & & & & & & & 1 & 1 & & & & & & & & & \\
\hline $\begin{array}{l}441 \mathrm{~B}-1, \mathrm{CC} \\
441 \mathrm{~B}-2-1,29-31 \\
441 \mathrm{~B}-2, \mathrm{CC}\end{array}$ & $\begin{array}{l}\mathrm{R} \\
\mathrm{R} \\
\mathrm{R}\end{array}$ & $\begin{array}{l}\mathrm{M} \\
\mathrm{M} \\
\mathrm{P}\end{array}$ & * & 1 & & $\begin{array}{l}1 \\
1\end{array}$ & 1 & 1 & & & & & & & & & & 1 & & & & & & & & & \\
\hline
\end{tabular}

pyloma. Holes 438A (Sections 438A-84-2-438A-86,CC) and 438B (Sections 438B-11-1-438B-13,CC) contain strata assigned to the zone. It probably correlates with part of the Calocycletta costata Zone and possibly with part of the $C$. virginis Zone of Riedel and Sanfilippo (1977) as well.

\section{Stichocorys armata Zone (new zone)}

This zone is defined by the range of Stichocorys delmontensis prior to the first appearance of Lithocarpium polyacantha. The base is synonymous with the Stichocorys delmontensis Zone of Riedel and Sanfilippo (1978). Riedel's and Sanfilippo's zone could not be recognized in the samples from DSDP Leg 57 because of the lack of Stichocorys wolffii, whose first occurrence defines the top of it. Sediments from Hole 438B (Sections 438B-15-2-438B-17-1) are placed in the Stichocorys armata Zone.

\section{Cannartus violina Zone (new zone)}

This zone is defined by the range of Cannartus violina prior to the first occurrence of Stichocorys delmontensis. This lower Miocene zone may correlate with part of the Cyrtocapsella tetrapera Zone of Riedel and Sanfilippo (1978). Hole 438B (Sections 438B-17-3438B-19-5) possesses radiolarian assemblages representative of the zone. 
TABLE 8 - Continued

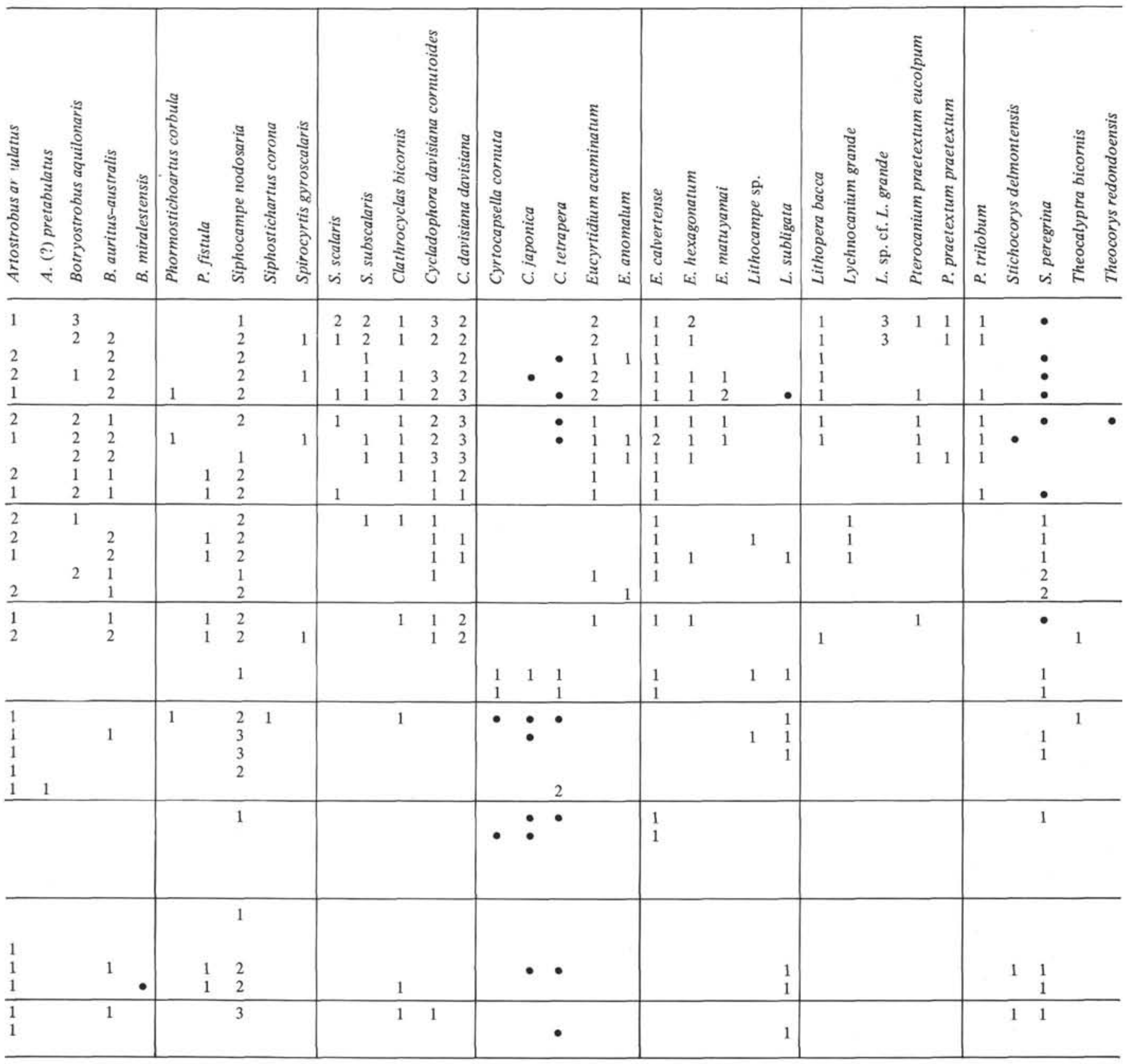

\section{Prunopyle titan Zone (new zone)}

This zone is defined as the range of Prunopyle titan and/or Cyrtocapsella tetrapera prior to the first occurrence of Cannartus violina. It is the oldest Neogene zone recognized in the present study and contains the following datums (from top to bottom). The first occurrence of Axoprunum angelinum and the nearly coeval first occurrence of Eucyrtidium calvertense and Cyrtocapsella cornuta. The zone is interpreted to correlate with the $C$. tetrapera Zone of Riedel and Sanfilippo (1978), which is lower Miocene in age. Holes 438B (Sections 438B-20-1438B-23,CC) and 439 (Sections 438-12-1-439-21-3) contain strata assigned to this zone. No zonal assignments are made below the base of the zone because diversity is too low.

\section{DISCUSSION}

\section{Correlation of Sites}

Using the zonal boundaries established in the proposed radiolarian zonation, it is possible to correlate the sites drilled on DSDP Leg 57 (see Figure 5). Such a correlation reveals that the sediment thickness representing equivalent time periods is variable from one hole to another. This variation could be caused by uneven sediment accumulation rates. An obvious example of this is the greater thickness of the Botryostrobus aquilonaris Zone, Axoprunum angelinum Zone, and Eucyrtidium matuyamai Zone in the holes at Site 440 relative to the other holes. This anomaly is due to the ponding of sediment of Site 440 since the beginning of the Pleistocene. 


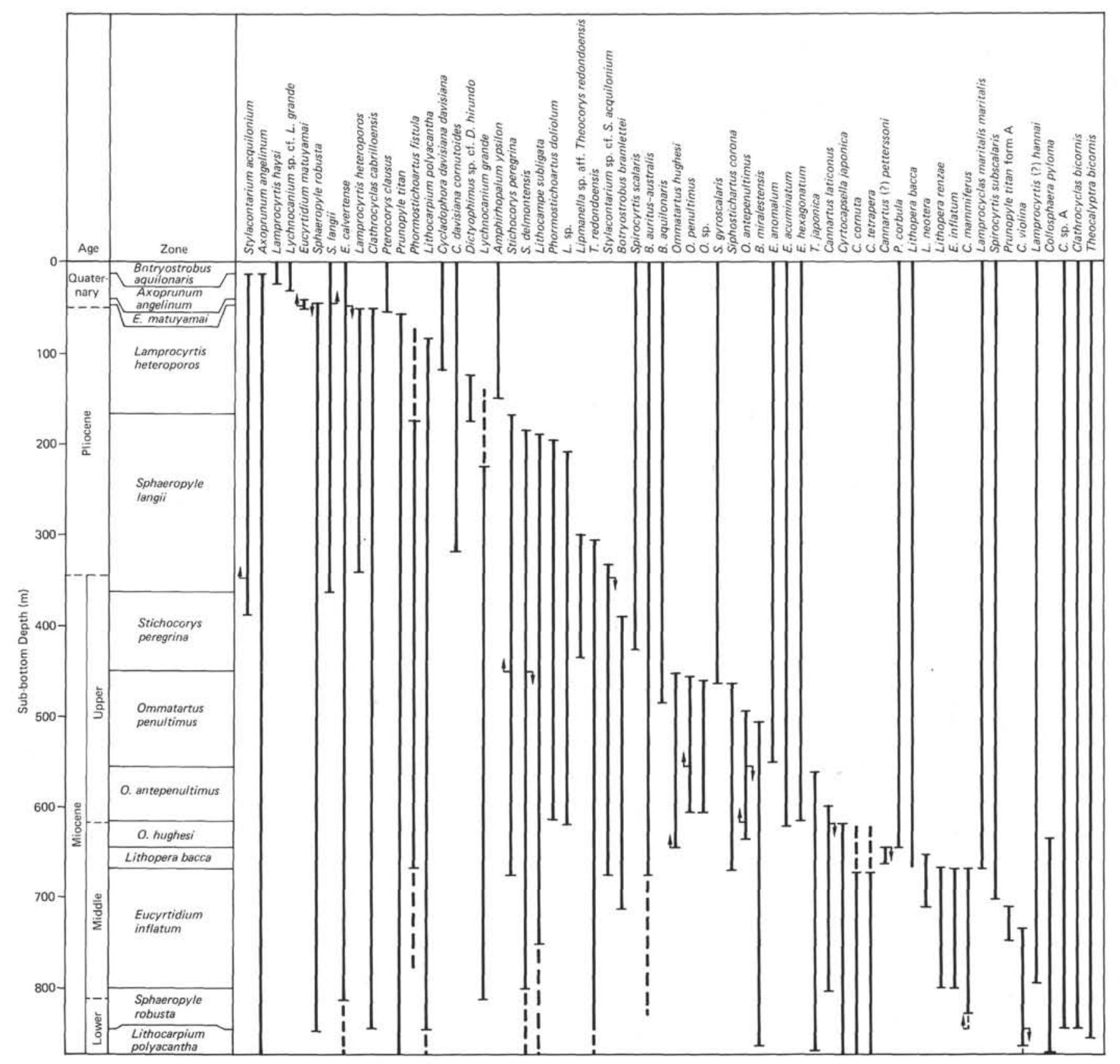

Figure 1. Range chart, DSDP Hole 438A.

Differences in sediment accumulation rates among holes could have been caused by one or a combination of the following factors: (1) differing sedimentation rates, (2) differing ammounts of compactions, and (3) the presence of hiatuses.

\section{Reworking}

Reworking of older radiolarian assemblages into younger ones proved to be an annoying problem throughout this investigation. This type of sample contamination was usually recognized by the sporadic or isolated occurrence in younger sediments of an extinct species which is continuously present during its normal range - for example, the occurrence of Eucyrtidium in- flatum in lower Pliocene sediments. The problem of determining whether or not sporadically occurring species had been reworked was difficult, because their "true" morphologic tops could not be pinpointed. This may account for the long range of some species.

Tables 1 to 8 list the samples in which reworking is readily recognized. The most intensive reworking was at Site 441, where lower to middle Miocene radiolarians nearly mask the Pleistocene to Pliocene assemblages. Reworking of predominantly Cretaceous and (possibly) early Paleogene radiolarian assemblages into the Oligocene sediments (dated by Keller, this volume) recovered from the lower portion of Hole 439 precluded radiolarian zonal assignments to these strata. 


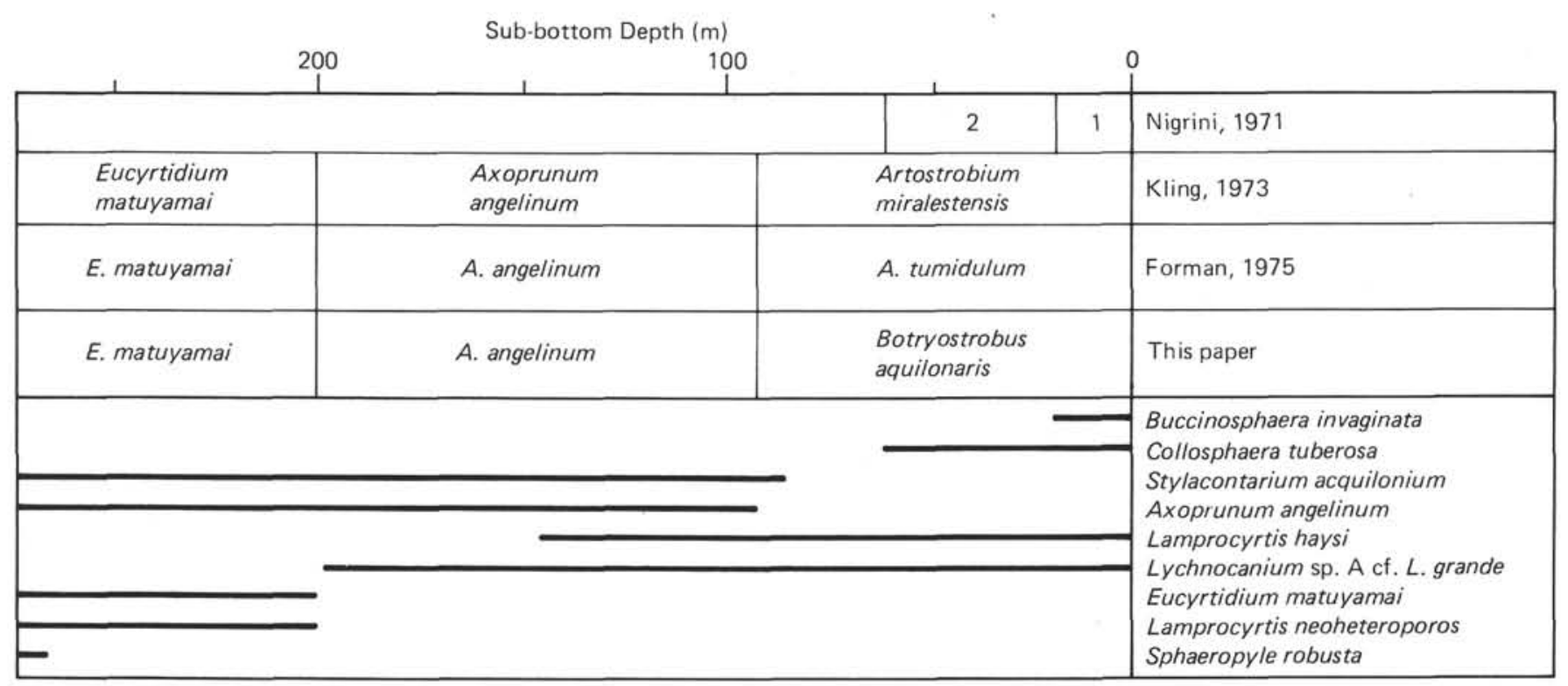

Figure 2. Range chart, DSDP Holes 440 and $440 \mathrm{~A}$.

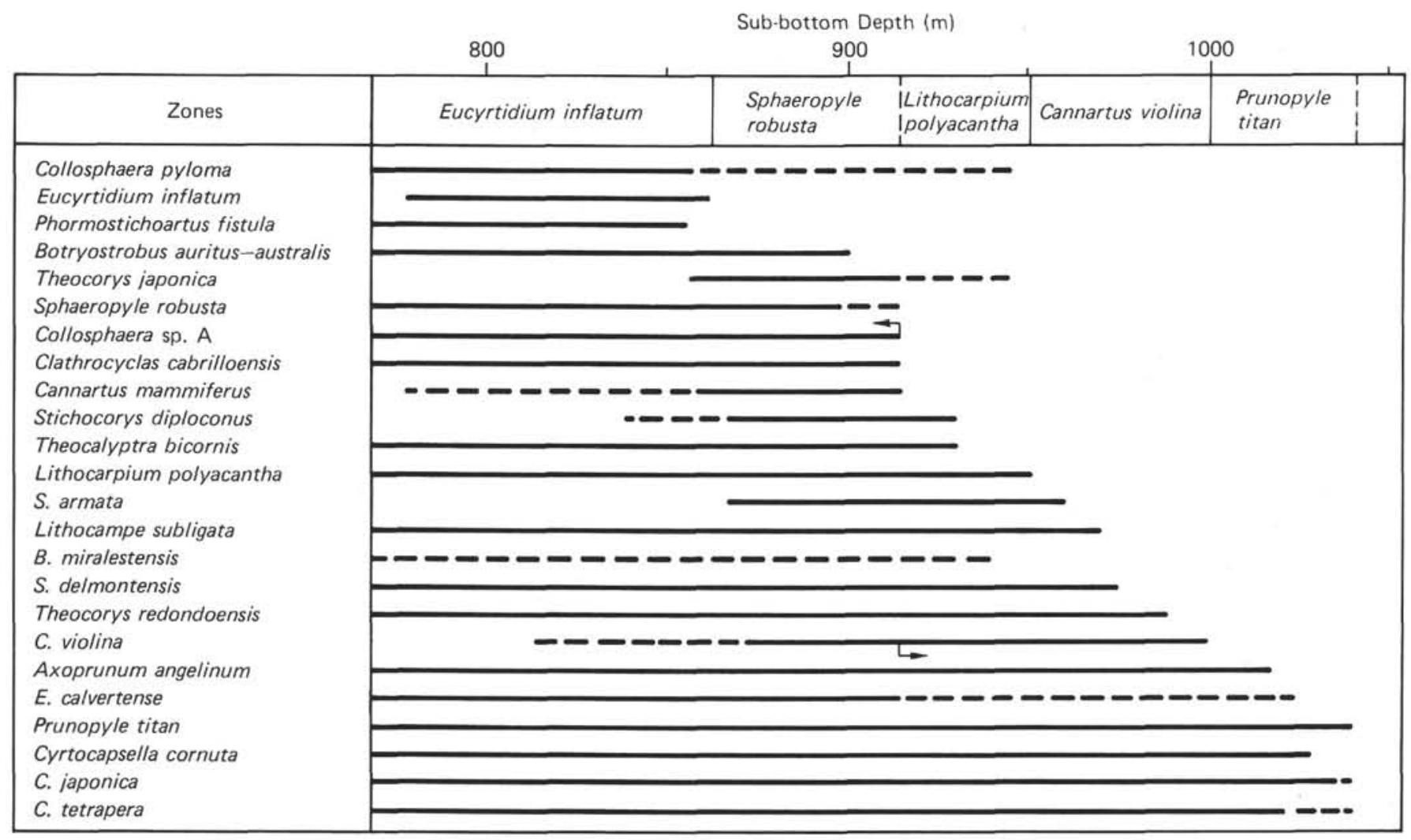

Figure 3. Range chart, DSDP Hole $438 B$.

\section{Paleotemperatures}

Paleotemperature is the only paleocologic factor presented in this report. Paleotemperatures were determined by using the presence or absence of artisciids and selected spongasters (Spongaster tetras tetras and $S$. pentas) in a sample. The abundance of these forms collectively was used to determine some minor variations.
Samples were categorized as either warm or cold and no absolute temperatures assigned.

Figure 6 shows the results of this analysis. The asterisks indicate samples in which thin-walled collasphaerids occurred. These forms indicate warm surface waters (Casey, 1972). Their presence within the inferred cold events probably represent pulses of warm surface water into the study area. Figure 6 also shows a paleo- 
TABLE 9

Radiolarian Datums

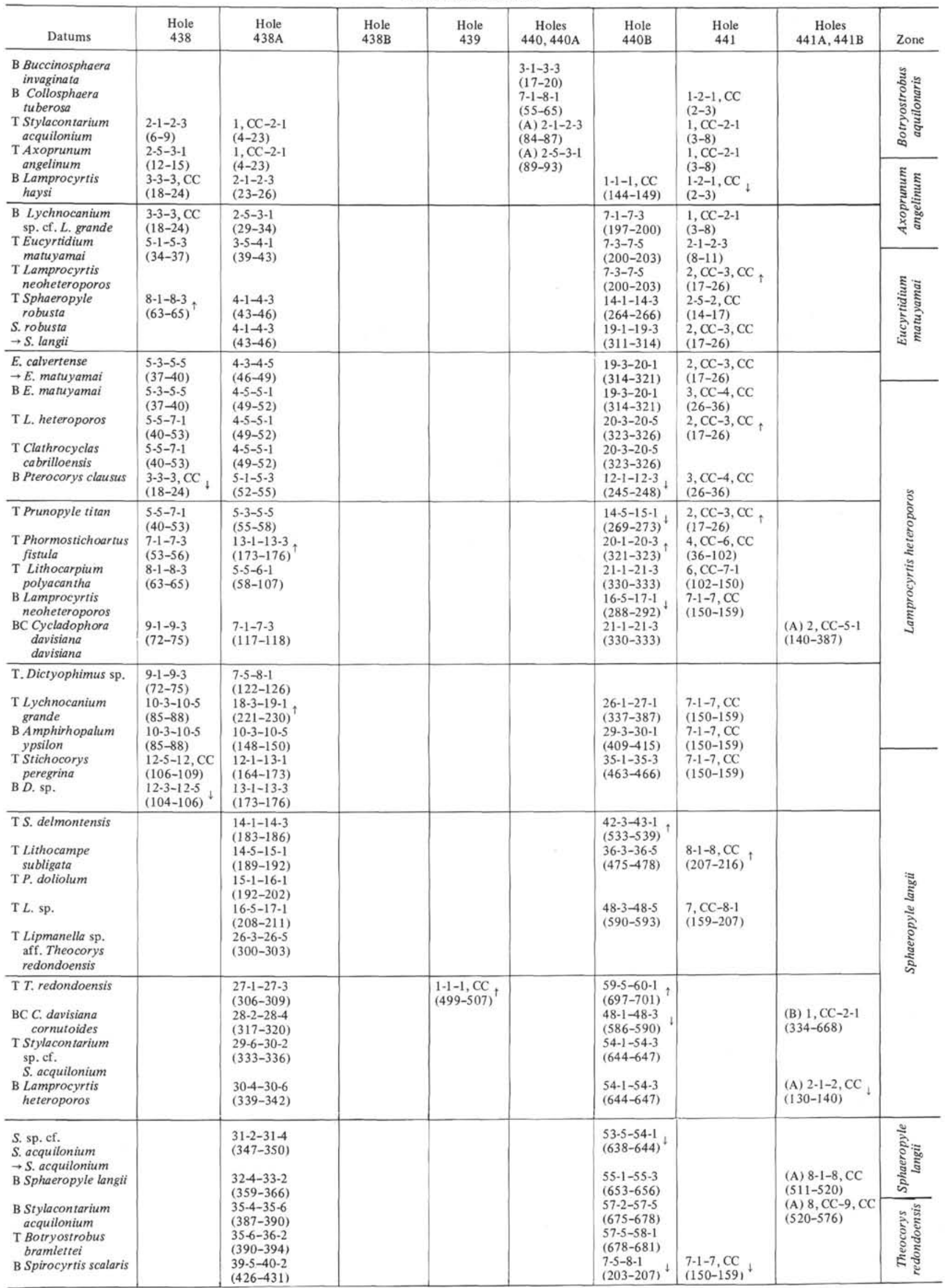


TABLE 9 - Continued

\begin{tabular}{|c|c|c|c|c|c|c|c|c|c|}
\hline Datums & $\begin{array}{c}\text { Hole } \\
438 \\
\end{array}$ & $\begin{array}{r}\text { Hole } \\
438 \mathrm{~A} \\
\end{array}$ & $\begin{array}{r}\text { Hole } \\
438 \mathrm{~B}\end{array}$ & $\begin{array}{c}\text { Hole } \\
439\end{array}$ & $\begin{array}{c}\text { Holes } \\
440,440 \mathrm{~A}\end{array}$ & $\begin{array}{r}\text { Hole } \\
440 \mathrm{~B} \\
\end{array}$ & $\begin{array}{c}\text { Hole } \\
441\end{array}$ & $\begin{array}{c}\text { Holes } \\
441 \mathrm{~A}, 441 \mathrm{~B} \\
\end{array}$ & Zone \\
\hline $\begin{array}{l}\text { B Lipmanella sp. aff. } \\
\text { Theocorys } \\
\text { redondoensis } \\
\text { Stichocorys } \\
\text { delmontensis } \\
\rightarrow S \text {. peregrina }\end{array}$ & & $\begin{array}{l}40-4-40-6 \\
(434-437) \\
42-1-42-3 \\
(449-453)\end{array}$ & & & & \multirow[t]{2}{*}{$\begin{array}{l}63-1-63-3 \\
(729-732)\end{array}$} & \multirow[b]{3}{*}{$\begin{array}{l}9-1-9, C C \\
(264-273)\end{array}$} & & 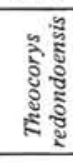 \\
\hline $\begin{array}{l}\text { T Ommatartus } \\
\text { hughesi } \\
\text { T O.penultimus } \\
\text { T Ommatartus sp. }\end{array}$ & & $\begin{array}{l}42-3-42-5 \\
(453-456) \\
42-5-43-2 \\
(546-460) \\
43-2-43-4 \\
(460-463) \\
\end{array}$ & & & & & & & \multirow{3}{*}{ 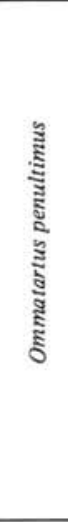 } \\
\hline $\begin{array}{l}\text { B Spirocyrtis } \\
\text { gyroscalaris } \\
\text { T Siphostichartus } \\
\text { corona } \\
\text { B B. aquilonaris } \\
\text { T O. antepenultimus } \\
\text { T B. miralestensis }\end{array}$ & & $\begin{array}{l}43-4-43-6 \\
(463-467) \\
43-4-43-6 \\
(463-467) \\
45-3-45-5 \\
(483-486) \\
46-4-46-6 \\
(493-496) \\
47-3-47-5 \\
(505-509) \\
\end{array}$ & & & & $\begin{array}{l}14-3-14-5 \\
(266-269) \\
+ \\
58-3-58-5 \\
(685-687)\end{array}$ & & $\begin{array}{l}\text { (A) } 2, \mathrm{CC}-5-1 \\
(140-387)\end{array}$ & \\
\hline $\begin{array}{l}\text { B E. anomalum } \\
\text { O. antepenultimus } \rightarrow\end{array}$ & & $\begin{array}{l}52-4-52-6 \\
(551-554) \\
52-6-53-2\end{array}$ & \multirow{4}{*}{$\begin{array}{l}4-1-4-3 \\
(854-857)\end{array}$} & \multirow[b]{2}{*}{$\begin{array}{l}1, \mathrm{CC}-2-1 \\
(507-556) \\
1-1-1, \mathrm{CC} \\
(499-507)\end{array}$} & & & & & \\
\hline $\begin{array}{l}\text { O. penultimus } \\
\text { Т.T. japonica } \\
\text { В O. penultimus } \\
\text { В O. sp. }\end{array}$ & & $\begin{array}{l}(554-557) \\
53-2-54-2 \\
(557-566) \\
58-1-59-1 \\
(603-612) \\
58-1-59-1 \\
(603-612) \\
\end{array}$ & & & & & & & \multirow{2}{*}{ 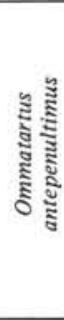 } \\
\hline $\begin{array}{l}\text { B } P . \text { doliolum } \\
\text { B E. hexagonatum } \\
\text { Cannartus laticonus }\end{array}$ & & $\begin{array}{l}59-1-59-3 \\
(612-615) \\
59-3-59-5 \\
(615-618) \\
59-5\end{array}$ & & \multirow{2}{*}{$\begin{array}{l}1-1-1, C C \\
(499-507) \\
\\
1-1-1, C C \\
(499-507) \\
2-1-2, C C \\
(556-564)\end{array}$} & & & & & \\
\hline $\begin{array}{l}\vec{O} \text {. antepenultimus } \\
\mathrm{B} E \text {. acuminatum } \\
\text { В Lithocampe sp. }\end{array}$ & & $\begin{array}{l}(618) \\
59-5-60-1 \\
(618-622) \\
59-5-60-1 \\
(618-622) \\
\end{array}$ & & & & & & & \multirow{3}{*}{ 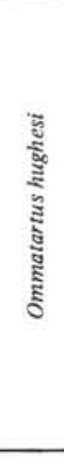 } \\
\hline $\begin{array}{l}\text { T Cyrtocapsella } \\
\text { tetrapera } \\
\text { T C. cornuta } \\
\text { T C. japonica } \\
\text { T Collosphaera } \\
\text { pyloma } \\
\text { B O. antepenultimus }\end{array}$ & & $\begin{array}{l}65-3-65-5 \\
(673-676) \\
65-3-65-5 \\
(673-676) \\
59-5-60-1 \\
(618-622) \\
60, C C-62-1 \\
(631-641) \\
60, C C-62-1 \\
(631-641)\end{array}$ & $\begin{array}{l}\begin{array}{l}6-3-7-1 \\
(875-883)\end{array} \\
\uparrow \\
2, C C-3-3 \\
(671-789)\end{array}$ & $\begin{array}{l}2-1-2, C C \\
(556-564) \\
2-1-2, C C \\
(556-564) \\
2, C C-3, C C \\
(664-658)\end{array}$ & & & & & \\
\hline $\begin{array}{l}\text { T Cannartus } \\
\text { petterssoni }\end{array}$ & & $\begin{array}{l}62-1-63-1 \\
(641-652)\end{array}$ & & & & & & & \\
\hline $\begin{array}{l}\text { C. petterssoni } \rightarrow \\
\text { O. hughesi } \\
\text { B } O \text {. hughesi } \\
\text { B P. corbula } \\
\text { T Lithopera neotera }\end{array}$ & & $\begin{array}{l}62-1-63-1 \\
(641-652) \\
62-1-63-1 \\
(641-652) \\
62-1-63-1 \\
(641-652) \\
63-1-64-1 \\
(652-660)\end{array}$ & $\begin{array}{l}2, \mathrm{CC}-3-3 \\
(671-789) \\
2, \mathrm{CC}-3-3 \\
(671-789)\end{array}$ & $\begin{array}{l}3, C C-4, C C \\
(658-754)\end{array}$ & & & & & 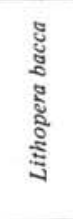 \\
\hline $\begin{array}{l}\text { B } C . \text { petterssoni } \\
\text { B } L . \text { bacca } \\
\text { T L. renzae } \\
\text { B } S . \text { corona } \\
\text { T E. inflatum }\end{array}$ & & $\begin{array}{l}64-3-64-5 \\
(663-666) \\
64-5-65-1 \\
(666-670) \\
64-5-65-1 \\
(666-670) \\
65-1-65-3 \\
(670-673) \\
65-1-65-3 \\
(670-673) \\
\end{array}$ & $\begin{array}{l}2, \mathrm{CC}-3-3 \\
(671-789) \\
\\
2, \mathrm{CC}-3-3 \\
(671-789) \\
2, \mathrm{CC}-3-3 \\
(671-789) \\
\end{array}$ & $\begin{array}{l}2-1-2, C C \\
(556-564)\end{array}$ & & & & & 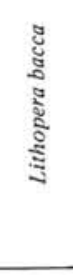 \\
\hline $\begin{array}{l}\text { T C. mammiferus } \\
\text { B Lamprocyclas } \\
\text { maritalis maritalis } \\
\text { B Stichocorys } \\
\text { peregrina } \\
\text { B Spirocyrtis } \\
\text { subscalaris } \\
\text { B Lithopera neotera }\end{array}$ & & $\begin{array}{l}65-1-65-3 \\
(670-673) \\
65-1-65-3 \\
(670-673) \\
65-5-66-2 \\
(676-679) \\
68-1-68-5 \\
(699-705) \\
68, C C-70-1 \\
(707-717)\end{array}$ & 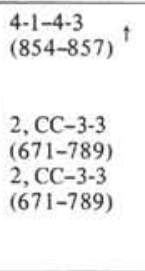 & $\begin{array}{l}2, \mathrm{CC}-3, \mathrm{CC}_{\downarrow} \\
(564-658) \\
2, \mathrm{CC}-3, \mathrm{CC} \\
(564-568)\end{array}$ & & & & $=$ & 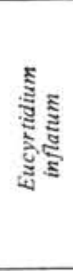 \\
\hline
\end{tabular}


TABLE 9 - Continued

\begin{tabular}{|c|c|c|c|c|c|c|c|c|c|}
\hline Datums & $\begin{array}{c}\text { Hole } \\
438\end{array}$ & $\begin{array}{l}\text { Hole } \\
438 \mathrm{~A}\end{array}$ & $\begin{array}{l}\text { Hole } \\
438 \mathrm{~B}\end{array}$ & $\begin{array}{c}\text { Hole } \\
439\end{array}$ & $\begin{array}{c}\text { Holes } \\
440,440 \mathrm{~A}\end{array}$ & $\begin{array}{l}\text { Hole } \\
440 B\end{array}$ & $\begin{array}{l}\text { Hole } \\
441\end{array}$ & $\begin{array}{c}\text { Holes } \\
441 \mathrm{~A}, 441 \mathrm{~B}\end{array}$ & Zone \\
\hline $\begin{array}{l}\text { B B. bramlettei } \\
\text { T Prunoplye titan } \\
\text { form A } \\
\text { T C. violina } \\
\text { B P. titan form A } \\
\text { T Stichocorys } \\
\text { diploconus }\end{array}$ & & $\begin{array}{l}68, C C-70-1 \\
(707-717) \\
68, C C-70-1 \\
(707-717) \\
72-1-72-3 \\
(736-739) \\
73-2-73-4 \\
(747-750) \\
75-1-76-1 \\
(764-774) \\
\end{array}$ & $\begin{array}{l}5-1-6-1 \\
(864-873)^{\dagger}\end{array}$ & $\begin{array}{l}3, C C-4, C C \\
(658-754) \\
10-3-11-1 \\
(900-907)^{\dagger}\end{array}$ & & & & , & \multirow[t]{2}{*}{ 롫 } \\
\hline $\begin{array}{l}\text { B Phormostrichoartus } \\
\text { fistula } \\
\text { B Lamprocyrtis } \\
\text { hannai } \\
\text { B E. inflatum } \\
\text { B Lithopera renzae } \\
\text { B C. laticonus }\end{array}$ & & $\begin{array}{l}64-5-65-1 \\
(666-670) \\
78-1-78-3 \\
(794-797) \\
78-3-79-2 \\
(797-805) \\
78-3-79-2 \\
(797-805) \\
79-2-79-4 \\
(805-808) \\
\end{array}$ & $\begin{array}{l}4-3-4-5 \\
(854-857) \\
4-5-5-1 \\
(860-864) \\
2, C C-3-3 \\
(671-879)\end{array}$ & $\begin{array}{l}3, \mathrm{CC}-4, \mathrm{CC} \\
(658-754)\end{array}$ & & & & & \\
\hline $\begin{array}{l}\text { T S. armata } \\
\text { B Lychnocanium } \\
\text { grande } \\
\text { B B. auritus-australis } \\
\text { B Sphaeropyle } \\
\quad \text { robusta } \\
\text { B Collosphaera sp. A }\end{array}$ & & $\begin{array}{l}79-2-79-4 \\
(805-808) \\
79-6-80-2 \\
(811-814) \\
65-5-66-2 \\
(676-679) \\
82, C C-84-2 \\
(840-851) \\
82, C C-84-2 \\
(840-851) \\
\end{array}$ & $\begin{array}{l}5-1-6-1 \\
(864-873) \\
2, C C-3-3 \\
(671-879) \\
9-1-9-3 \\
(900-904) \\
8-1-9-1 \\
(892-900) \\
10-1-11-1 \\
(910-920)\end{array}$ & $\begin{array}{l}3, C C-4, C C \\
(658-754) \\
9-3-9-5 \\
(891-894) \\
11-1-11-3 \\
(907-910) \\
11-1-11-3 \\
(907-910) \\
\end{array}$ & & & & $=$ & 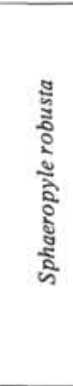 \\
\hline $\begin{array}{l}\text { B Clathrocyclas } \\
\text { cabrilloensis } \\
\text { B C. bicornis } \\
\text { Cannartus violina } \\
\overrightarrow{\text { B C. mammiferus }} \\
\text { B Stichocorys } \\
\text { diploconus }\end{array}$ & & $\begin{array}{l}82, C C-84-2 \\
(840-851) \\
82, C C-84-2 \\
(840-851) \\
80, C C-82-2 \\
(821-835) \\
76-1-77-1 \\
(774-784)\end{array}$ & $\begin{array}{l}10-1-11-1 \\
(910-920) \\
10-1-11-1 \\
(910-920) \\
10-1-11-1 \\
(910-920) \\
10-1-11-1 \\
(910-920) \\
12-1-12-3 \\
(930-932)\end{array}$ & $\begin{array}{l}2, \mathrm{CC}-3, \mathrm{CC} \\
(564-658) \\
4, \mathrm{CC}-5-1 \\
(754-851)\end{array}$ & & & & & \multirow{2}{*}{ 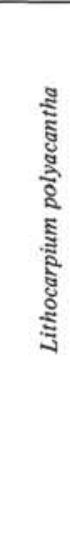 } \\
\hline $\begin{array}{l}\text { B Theocalyptra } \\
\text { bicornis } \\
\text { B B. miralestensis } \\
\text { B Theocorys } \\
\text { japonica } \\
\text { B Collosphaera } \\
\text { pyloma } \\
\text { B Lithocarpium } \\
\text { polyacantha }\end{array}$ & & $\begin{array}{l}84-2-85-2 \\
(851-861) \\
85-4-85, \mathrm{CC} \\
(864-868) \\
85, \mathrm{CC}-86, \mathrm{CC} \\
(868-878) \\
86, \mathrm{CC} \\
(878) \\
82, \mathrm{CC}-84-2 \\
(840-851)\end{array}$ & $\begin{array}{l}12-1-12-3 \\
(930-932) \\
10-1-11-1 \\
(910-920) \\
4-3-4-5 \\
(857-860) \\
13, \text { CC-15-2 } \\
(948-959)\end{array}$ & $\begin{array}{l}3, \mathrm{CC}-4, \mathrm{CC} \\
(658-754) \\
10-3-11-1 \\
(900-907)\end{array}$ & & & & & \\
\hline $\begin{array}{l}\text { B } S \text {. armata } \\
\text { B Lithocampe } \\
\text { subligata } \\
\text { B } S \text {. delmontensis } \\
\text { B } T \text {. redondoensis } \\
\text { B Cannartus violina }\end{array}$ & & $\begin{array}{l}79-4-79-6 \\
(808-811) \\
73-4-73-6 \\
(750-753) \\
78-3-79-2 \\
(797-805) \\
80, C C-82-2 \\
(840-851) \\
85-4-85, C C \\
(864-868)\end{array}$ & $\begin{array}{l}15-2-16-1 \\
(959-967) \\
16-1-17-1 \\
(967-976) \\
17-1-17-3 \\
(976-979) \\
18-3-18-5 \\
(989-992) \\
19-5-20-1 \\
(1002-1005)\end{array}$ & $\begin{array}{l}3, C C-4, C C_{\downarrow} \\
(658-754) \\
3, C C-4, C C_{\downarrow} \\
(658-754) \\
11-3-12-1 \\
(910-917)\end{array}$ & & & & & 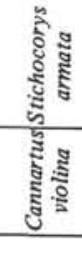 \\
\hline $\begin{array}{l}\text { B Axoprunum } \\
\text { angelinum } \\
\text { B E. calvertensis } \\
\text { B Cyrtocapsella } \\
\text { cornuta } \\
\text { B C. tetrapera } \\
\text { B C. japonica }\end{array}$ & & $\begin{array}{l}\begin{array}{l}80-2-80-4 \\
(814-816)\end{array} \\
\\
85, C C-86, C_{\downarrow} \\
(868-878)\end{array}$ & $\begin{array}{l}21-3-22-1 \\
(1018-1024) \\
10-1-11-1 \\
(910-920) \\
22-1-23-1 \\
(1024-1034) \\
23-1-23, C C \\
(1034-1039) \\
21-3-22-1 \\
(1018-1024)\end{array}$ & $\begin{array}{l}13-1-13-3 \\
(926-929) \\
18-3-19-1 \\
(967-974) \\
\\
21-3-22-1 \\
(996-1001) \\
21-3-22-1 \\
(996-1001)\end{array}$ & & & & & \multirow[t]{2}{*}{ 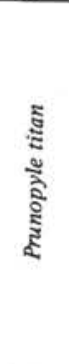 } \\
\hline B P. titan & & & $\begin{array}{l}23, \mathrm{CC}-24, \mathrm{CC} \\
(1039-1041)\end{array}$ & $\begin{array}{l}21-3-22-1 \\
(996-1001)\end{array}$ & & & & & \\
\hline
\end{tabular}




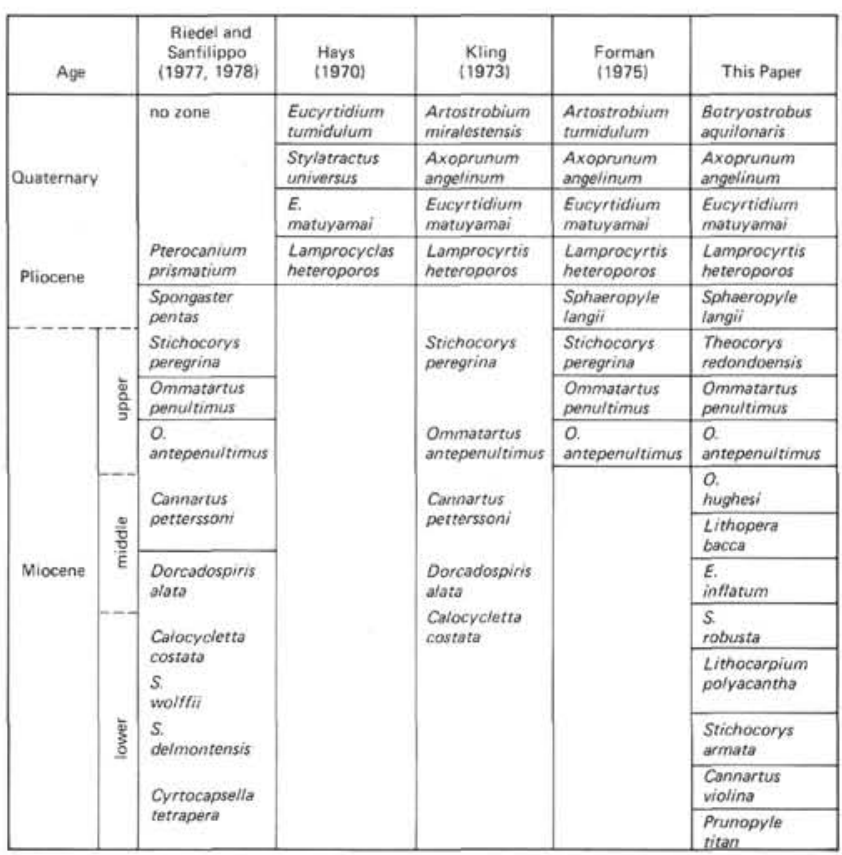

Figure 4. Correlation of radiolarian zonations.

temperature curve for Southern California from Casey (personal communication and 1972). A comparison of the two curves reveals that the maximum of the cold (and warm) events are not in phase. This could be due to the poor biostratigraphic control used to correlate the two curves. The phase difference is of the order of 0.25 to $0.5 \mathrm{~m} . \mathrm{y}$. , with Southern California lagging behind Japan. Therefore the paleotemperatures indicate a cooling (or warming) event first in Japan and then in Southern California. The lag indicates that temperate and/or tropical assemblages are displaced by subarctic and arctic assemblages in Japan first. Moore (1978) shows the expansion of the "Subarctic Factor" (assemblage) and an exclusion of the "Tropical Factor" and "Transitional Factor" during a glacial epoch in the Japan region. For Southern California he shows the "Tropical Factor" and "Transitional Factor" expanding and the "Subarctic Factor" receding during a glacial epoch. Therefore, according to Moore's (1978) data, the two regions may be out of phase by $180^{\circ}$ (this aspect is currently being investigated by the author).

\section{TAXONOMIC NOTES}

This section provides the reader with a reference containing partial synonomy and/or description and illustration of the species referred to in this study. Remarks clarify the concept of certain species as used herein. The section also provides the description of a new species. The taxonomic framework used closely follows that of Riedel (1971) for the spumellarians and Petrushevskaya (1971) for the nassellarians.

\section{Family COLLOSPHAERIDAE Müller 1858}

\section{Buccinosphaera invaginata Haeckel}

Buccinosphaera invaginata Haeckel in Nigrini, 1971, p. 445, pl. 34.1 , figs. 19, 20.
Collosphaera sp. A

(Plate 1, Figures 1-4)

This species possesses the wide platforms between the pores which are typical for the genus, but the wall is typically very robust. The test is always elliptical in shape and is pierced by few to many small pores, which are irregularly disposed. The major and minor axes of this species range between $80 \mu \mathrm{m}$ to $130 \mu \mathrm{m}$ and $65 \mu \mathrm{m}$ to $95 \mu \mathrm{m}$ respectively. Stratigraphically lower forms tend to be more robust and possess few pores.

Remark: This concept of the species is very general and may in the future be modified to include two species or subspecies. The ranges of these two forms overlap with the stratigraphically lower of the two being more robust than the stratigraphically higher form.

Range: Base of Sphaeropyle robusta Zone to Recent.

\section{Collosphaera pyloma n. sp. \\ (Plate 1, Figures 5-9)}

This unusual thick-walled collosphaerid possesses a pylome-like structure. The relatively smooth surface of the test is irregularly interrupted by very small circular to subcircular pores of similar size (approximately $3-4 \mu \mathrm{m}$ ). The overall shape of the test is that of a prolate ellipsoid with a minor axis of approximately $80 \mu \mathrm{m}$ and a major axis of about $110 \mu \mathrm{m}$. Small teeth are present at the termination of the pylome.

Range: Lower part of Lithocarpium polyacantha Zone to lower part of Ommatartus hughesi Zone.

Holotype: Sample 438A-78-3, 90-92 cm, Slide \#1, H 14/3 (Plate 1, Figures 7 and 8).

Type locality: Northwest Pacific Ocean, Sample 438A-78-3, 90-92 $\mathrm{cm}$.

Repository: Rice University Micropaleontology Collection.

\section{Collosphaera sp. B}

Collosphaera sp. A in Knoll and Johnson, 1975, pl. 1, figs. 1, 2; pl. 2, figs. 4-6, p. 63.

\section{Collosphaera tuberosa Haeckel}

Collosphaera tuberosa Haeckel in Nigrini, 1971, p. 445, pl. 34.1, fig. 1.

\section{Family ACTINOMMIDAE Haeckel 1862, emend. Riedel 1967}

\section{Axoprunum angelinum (Campbell and Clark)}

Axoprunum angelinum (Campbell and Clark) in Kling, 1973, p. 634, pl. 1 , figs. $13-16$; pl. 6 , figs. 14-18.

\section{Sphaeropyle langii Dreyer}

Sphaeropyle langii Dreyer in Forman, 1975, p. 618, pl. 9, figs. 30-31. Remark: S. langii is distinguished from S. robusta on the basis set forth by Forman, 1975. The second-outermost shell contains large, irregularly arranged pores, fewer than 12 in number on half the circumference.

\section{Sphaeropyle robusta Kling}

Sphaeropyle robusta Kling emend. in Forman, 1975, p. 618, pl. 9, figs. 24-26.

Remark: $S$. robusta is distinguished from $S$. langii by having small, regularly disposed pores on the second-outermost shell.

\section{Stylacontarium acquilonium (Hays)}

Stylacontarium acquilonium (Hays) in Kling, 1973, p. 634, pl. 1, figs. $17-20$; pl. 14 , figs. $1-4$.

Remark: Individuals categorized under this species contain the protrusions of the elliptical medullary shell along the connecting bars noted by Kling (1973).

\section{Stylacontarium sp. cf. S. acquilonium}

Stylacontarium sp. aff. S. bispiculium of Kling, 1973, p. 634, pl. 6, figs. 19-23; pl. 14, figs. 5-8.

Remark: Similar to $S$. acquilonium but lacks the protrusions of the elliptical medullary wall along the connecting bars. Kling (1973) noted 


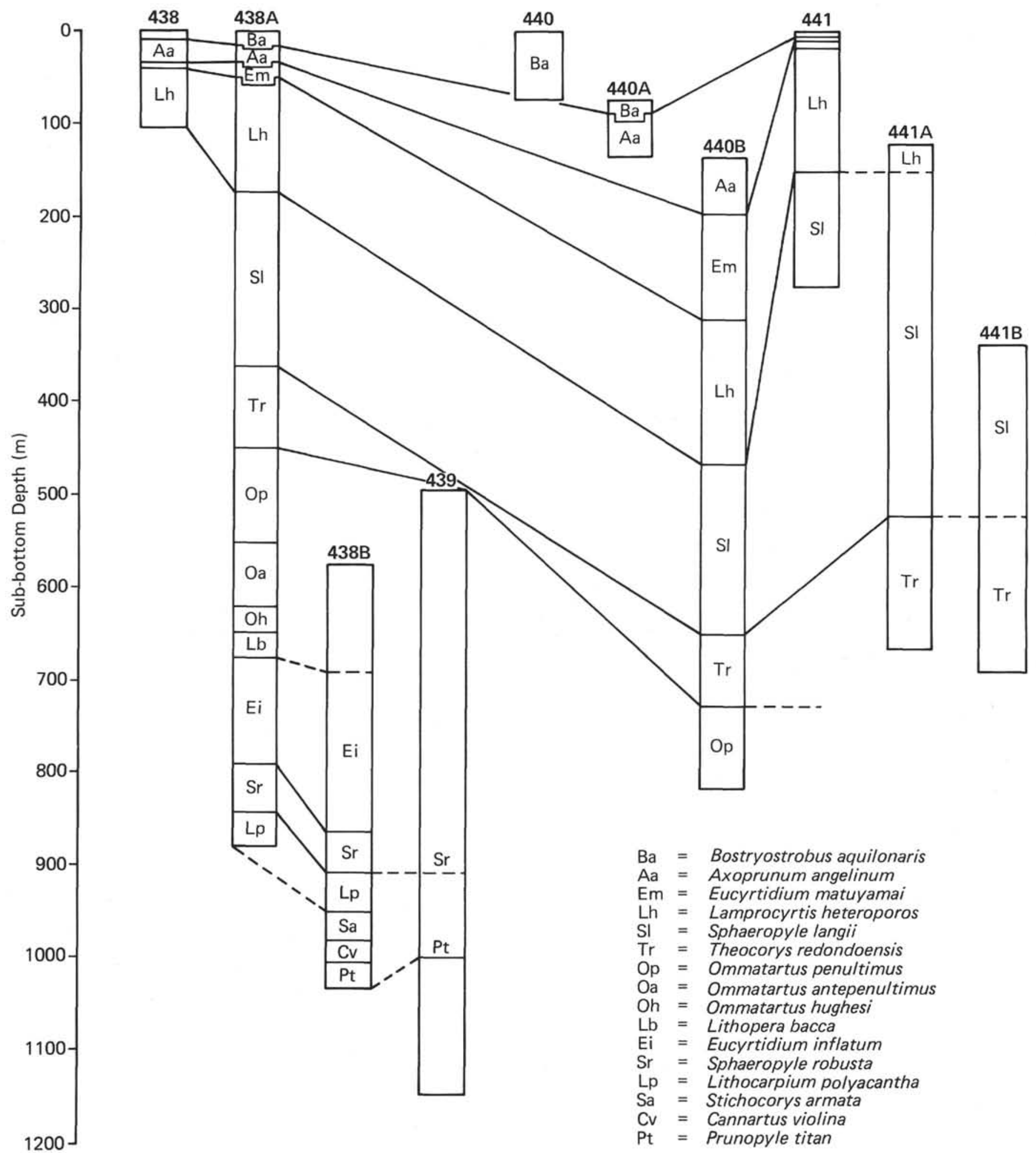

Figure 5. Correlation of holes drilled on DSDP Leg 57. 

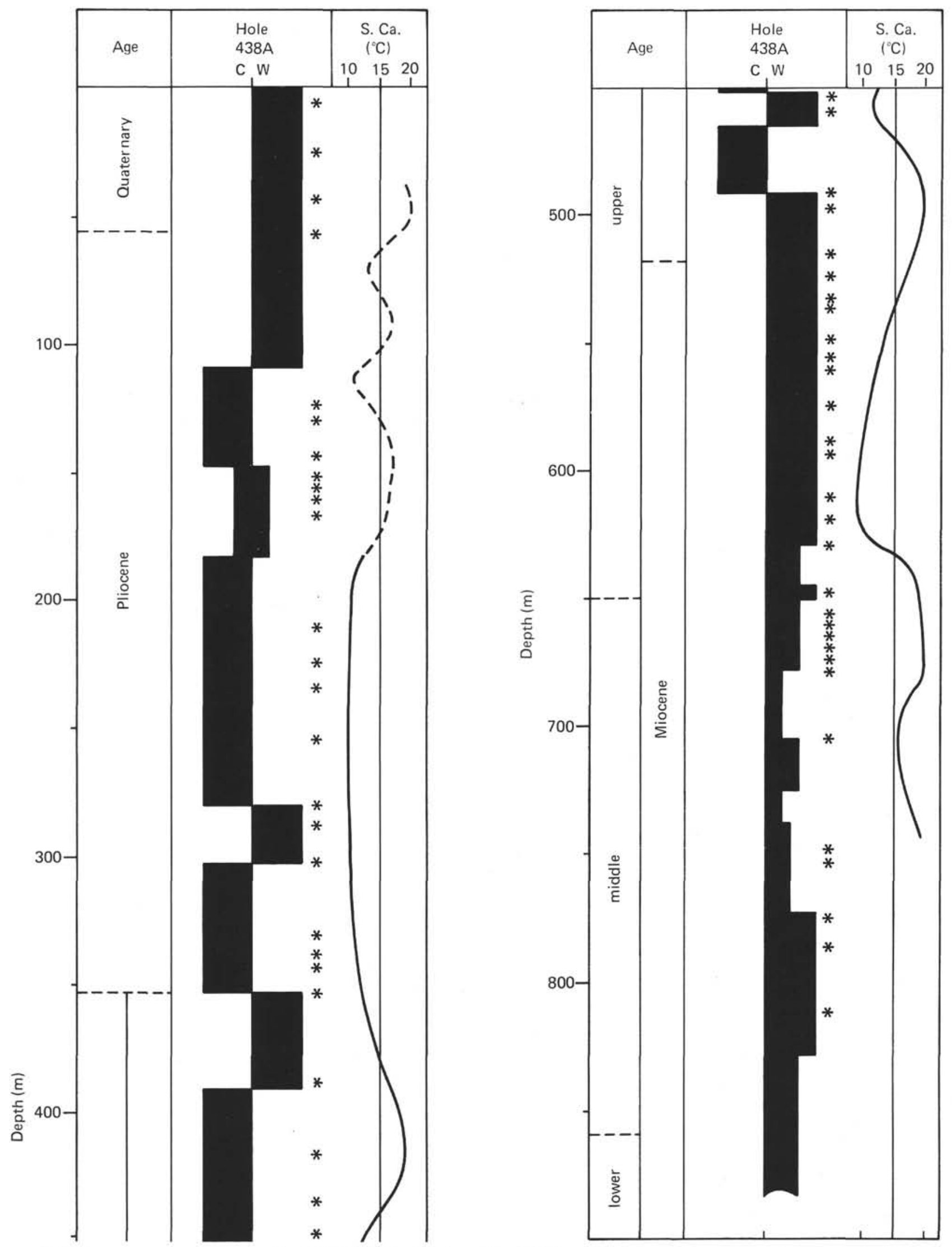

Figure 6. Paleotemperature curves for DSDP Hole 438A and S. California (after Casey, personal communication, and 1972) related to depth in DSDP Hole $438 A$ and its associated age assignments. Asterisks indicate samples containing warm-water collosphaerids. 
that this species may be the ancestor of $S$. acquilonium. In this study it is treated as such, and the transition between the two is very close to or at the Miocene/Pliocene boundary.

\section{Subfamily ARTISCINAE Haeckel 1881, emend. Riedel 1967}

\section{Cannartus laticonus Riedel}

Cannartus laticonus Riedel in Westberg and Riedel, 1978, p. 20, pl. 2, figs. 1-3.

\section{Cannartus mammiferus (Haeckel)}

Cannartus mammiferus (Haeckel) in Riedel and Sanfilippo, 1971, p. 1587, pl. 2C, figs. 1-3.

\section{Cannartus (?) petterssoni Riedel and Sanfilippo}

Cannartus (?) petterssoni Riedel and Sanfilippo, in Riedel and Sanfilippo, 1971, p. 1587, pl. 1C, figs. 19, 20.

Cannartus violina Haeckel .

Cannartus violina Haeckel in Riedel and Sanfilippo, 1971, p. 1588, pl. 2C, figs. 4-7.

Ommatartus antepenultimus Riedel and Sanfilippo

Ommatartus antepenultimus Riedel and Sanfilippo in Westberg and Riedel, 1978, p. 22, pl. 2, figs. 4, 5.

Ommatartus hughesi (Campbell and Clark)

Ommatartus hughesi (Campbell and Clark) in Riedel and Sanfilippo, 1971 , p. 1588 , pl. 1C, figs. 17,18 .

Ommatartus penultimus (Riedel)

Ommatartus penultimus (Riedel) in Westberg and Riedel, 1978, p. 22, pl. 2, figs. 6-8.

Ommatartus sp.

This species lacks the well-developed equatorial constriction typical of most species of Ommatartus. Although some individuals possess small polar caps, most lack any sign of one. May be closely related to Ommatartus antepenultimus.

\section{Ommatartus tetrathalamus (Haeckel)}

Ommatartus tetrathalamus (Haeckel) in Riedel and Sanfilippo, 1971, p. 1588, pl. $1 \mathrm{C}$, figs. 6,7 .

Family SPONGODISCIDAE Haeckel 1862, emend. Riedel 1967

Amphirhopalum ypsilon Haeckel

Amphirhopalum ypsilon Haeckel in Nigrini, 1971, p. 447, pl. 34.1, figs. $7 \mathrm{a}-\mathrm{c}$.

Spongaster pentas Riedel and Sanfilippo

Spongaster pentas Riedel and Sanfilippo, 1970, p. 523, pl. 15, fig. 3.

Spongaster tetras Ehrenberg irregularis Nigrini

Spongaster tetras irregularis Nigrini, 1967, p. 43, pl. 5, fig. 2.

Spongaster tetras tetras Ehrenberg

Spongaster tetras Riedel and Sanfilippo, 1971, p. 1589, pl. 1D, figs. 2-4.

Family LITHELIIDAE Haeckel 1862

Lithocarpium polyacantha (Campbell and Clark)

Larnacantha polyacantha Campbell and Clark, 1944 (in part), p. 30, pl. 5 , figs. 6,7 .

Lithocarpium polyacantha (Campbell and Clark) group in Petrushevskaya, 1975 (in part), p. 572, pl. 3 , figs. 7,8 .

Remark: Presence of inner medullary structures in individuals of this species distinctly distinguish them from individuals of Prunopyle titan. Thick cortical walls are common and the surface may have a spinose texture.

\section{Prunopyle titan Campbell and Clark}

Prunopyle titan Campbell and Clark, 1944, p. 20, pl. 3, figs. 1-3.

Remark: Included within this species are individuals that lack inner medullary structures. Those containing such structures are placed under Lithocarpium polyacantha.

\section{Prunopyle titan Campbell and Clark form A}

(Plate 1, Figure 10)

Differs from $P$. titan by its enormous size $(860 \mu \mathrm{m})$ and more spherical shape. Only a few specimens were found, but it seems useful to separate this form out because of its limited range in the Eucyrtidium inflatum Zone.

Family PTEROCORYIDAE Haeckel 1881, emend. Riedel 1967

Lamprocyclas maritalis maritalis Haeckel

Lamprocyclas maritalis maritalis Haeckel in Nigrini, 1967, p. 74, pl. 7 , fig. 5 .

Lamprocyclas maritalis Haeckel polypora Nigrini

Lamprocyclas maritalis polypora Nigrini, 1967, p. 76, pl. 7, fig. 6 .

Lamprocyrtis (?) hannai (Campbell and Clark)

Lamprocyrtis (?) hannai (Campbell and Clark) in Kling, 1973, p. 638, pl. 5, figs. 12-14; pl. 12, figs. 10-14.

\section{Lamprocyrtis haysi Kling}

Lamprocyrtis haysi Kling, 1973, p. 639, pl. 15, figs. 1-3.

\section{Lamprocyrtis heteroporos (Hays)}

Lamprocyrtis heteroporos (Hays) in Kling, 1973, p. 639, pl. 5, figs. $19,20$.

\section{Lamprocyrtis neoheteroporos Kling}

Lamprocyrtis neoheteroporos Kling, 1973, p. 639, pl. 5, figs. 17, 18; pl. 15 , figs. 4, 5.

Remark: This species is not continuously present or abundant in any of the sections examined.

\section{Pterocorys clausus (Popofsky) group}

Pterocorys clausus group (Popofsky) in Petrushevskaya and Kozlova, 1972 , p. 545 , pl. 36 , figs. $16-18$.

Remark: Individuals of this species have abdomens that are variable (strongly convex to straight). Mouth may be closed or open but is usually constricted.

Theocorythium trachelium (Ehrenberg) dianae (Haeckel)

Theocorythium trachelium (Ehrenberg) dianae (Haeckel) in Nigrini, 1967 , p. 77 , pl. 8 , figs. 1a, 1b; pl. 9 , figs. 1a, 1b.

Theocorythium trachelium trachelium (Ehrenberg)

Theocorythium trachelium trachelium (Ehrenberg) in Nigrini, 1967, p. 79 , pl. 8 , fig. 2 .

\section{Theocorythium vetulum Nigrini}

Theocorythium vetulum Nigrini, 1971, p. 447, pl. 1, figs. 6a, 6b.

Family ARTOSTROBIIDAE Riedel 1967

Artostrobus annulatus (Bailey)

Artostrobus annulatus (Baily) in Petrushevskaya, 1975, pl. 10, figs. 4,5 .

Artostrobus (?) pretabulatus Petrushevskaya

Artostrobus (?) pretabulatus Petrushevskaya, 1975, p. 580, pl. 10, figs. 2,3 .

Botryostrobus aquilonaris (Bailey)

Botryostrobus aquilonaris (Bailey) in Nigrini, 1977, p. 246, pl. 1, fig. 1 . 
Botryostrobus auritus-australis (Ehrenberg) group

Botryostrobus auritus-australis (Ehrenberg) group in Nigrini, 1977, p. 246 , pl. 1 , figs. $2-5$.

Botryostrobus bramlettei (Campbell and Clark)

Botryostrobus bramlettei (Campbell and Clark) in Nigrini, 1977, p. 248 , pl. 1 , figs. 7,8 .

Botryostrobus miralestensis (Campbell and Clark)

Botryostrobus miralestensis (Campbell and Clark) in Nigrini, 1977, p. 249 , pl. 1, fig. 9.

Phormostichoartus corbula (Harting)

Phormostichoartus corbula (Harting) in Nigrini, 1977, p. 252, pl. 1, fig. 10.

Phormostichoartus doliolum (Riedel and Sanfilippo)

Phormostichoartus doliolum (Riedel and Sanfilippo) in Nigrini, 1977, p. 252 , pl. 1 , fig. 14 .

Phormostichoartus fistula Nigrini

Phormostichoartus fistula Nigrini, 1977, p. 253, pl. 1, figs. 11-13.

Phormostichoartus marylandiscus (Martin)

Phormostichoartus marylandiscus (Martin) in Nigrini, 1977, p. 253, pl. 2, figs. 1-3.

Siphocampe arachnea (Ehrenberg) group

Siphocampe arachnea (Ehrenberg) group in Nigrini, 1977, p. 255, pl. 3 , figs. 7,8 .

Siphocampe nodosaria (Haeckel)

Siphocampe nodosaria (Haeckel) in Nigrini, 1977, p. 256, pl. 3, fig. 11.

Siphostichartus corona (Haeckel)

Siphostichartus corona (Haeckel) in Nigrini, 1977, p. 257, pl. 2, figs. 5-7.

Spirocyrtis gyroscalaris Nigrini

Spirocyrtis gyroscalaris Nigrini, 1977, p. 258, pl. 2, figs. 10, 11.

Spirocyrtis scalaris Haeckel

Spirocyrtis scalaris Haeckel in Nigrini, 1977, p. 259, pl. 2, figs. 12, 13

\section{Spirocyrtis subscalaris Nigrini}

Spirocyrtis subscalaris Nigrini, 1977, p. 259, pl. 3, figs. 1, 2.

Family EUCYRTIDIIDAE Ehrenberg 1847, emend. Petrushevskaya 1971

Clathrocyclas bicornis Hays

Clathrocyclas bicornis Hays, 1965, p. 179, pl. III, fig. 3 .

Remark: Clathrocyclas bicornis differs from Theocalyptra bicornis by having a smaller length-to-width ratio, a much thicker wall, and a different type of internal structure.

\section{Clathrocyclas cabrilloensis Campbell and Clark}

(Plate 1, Figures 15 and 16)

Clathrocyclas (Clathrocycloma) cabrilloensis Campbell and Clark, 1944 , p. 48 , pl. 7 , figs. $1,2$.

Remark: Many different forms are grouped under this species, but all of them have surface spines.

Cycladophora davisiana (Ehrenberg) cornutoides Petrushevskaya

Cycladophora davisiana (Ehrenberg) var. cornutoides Petrushevskaya, 1967 , p. 126 , fig. 70 , I-III.
Cycladophora davisiana davisiana (Ehrenberg)

Cycladophora davisiana (Ehrenberg) in Petrushevskaya, 1967, p. 122, fig. 69 , I-VII.

\section{Cyrtocapsella cornuta Haeckel}

Cyrtocapsella cornuta Haeckel in Sanfilippo and Riedel, 1970, p. 453, pl. 1, figs. 19, 20; Kling, 1973, pl. 11, figs. 16-18.

Remark: Individuals without truly hemispherical fourth segments are included in this species. The campanulate shape of the third segment was the principle character used to separate this species from $C$. tetrapera, which has a third segment with nearly parallel walls.

\section{Cyrtocapsella japonica (Nakaseko)}

Cyrtocapsella japonica (Nakaseko) in Sanfilippo and Riedel, 1970, p. 542 , pl. 1 , figs. $13-15$.

\section{Cyrtocapsella tetrapera Haeckel}

Cyrtocapsella tetrapera Haeckel in Sanfilippo and Riedel, 1970, p. 543 , pl. 1, figs. 16-18.

\section{Eucyrtidium acuminatum (Ehrenberg)}

Eucyrtidium acuminatum (Ehrenberg) in Kling, 1973, pl. 4, figs. 20-23.

\section{Eucyrtidium anomalum Haeckel}

Eucyrtidium anomalum Haeckel, 1862, p. 323, pl. 4, figs. 11-13.

Eucyrtidium calvertense Martin

Eucyrtidium calvertense Martin in Kling, 1973, pl. 4, figs. 16, 18, 19; pl. 11, figs. 1-5.

Remark: Differences in size between $E$. calvertense and $E$. matuyamai was significant and was used to distinguish the two species.

Eucyrtidium hexagonatum Haeckel

Eucyrtidium hexagonatum Haeckel in Nigrini, 1967, p. 83, pl. 8 , figs. $4 a-b$.

\section{Eucyrtidium inflatum}

Eucyrtidium inflatum Kling, 1973, p. 535, pl. 11, fig. 7; pl. 15, figs. 7-10.

Eucyrtidium matuyamai Hays

Eucyrtidium matuyamai Hays, 1970, p. 213, pl. 1, figs. 7-9; Kling, 1973, pl. 4, fig. 17.

Lipmanella sp. aff. Theocorys redondoensis (Plate 1, Figures 17 and 18)

Cephalis is similar to that of Theocorys redondoensis. The primary difference between this species and its probable ancestor, $T$. redondoensis, is the lack of a truly spherical and robust thorax and the presence of wings that are initially three-bladed on the thorax of Lipmanella sp. aff. Theocorys redondoensis.

\section{Lithocampe sp. \\ (Plate 1, Figure 19)}

A five-segmented species with the first four segments similar to those of species of Cyrtocapsella and Stichocorys. The fifth segment is narrower than the fourth and may be either open or closed. It may be inverted cap-shape or campanulate. This species differs from Cyrtocapsella tetrapera and $C$. cornuta in that their fourth segment is closed and from species of Stichocorys by the lack of more than five chambers.

\section{Lithocampe subligata Stohr}

Lithocampe (Lithocampe) subligata Stohr group in Petrushevskaya, 1975 , p. 581 , pl. 14 , figs. $6-9,12$.

\section{Lithopera bacca Ehrenberg}

Lithopera bacca Ehrenberg in Nigrini, 1967, p. 54, pl. 6, fig. 2. 
Lithopera neotera Sanfilippo and Riedel

Lithopera (Lithopera) neotera Sanfilippo and Riedel, 1970, p. 454, pl. 1, figs. 24-26, 28 .

\section{Lithopera renzae Sanfilippo and Riedel}

Lithopera (Lithopera) renzae Sanfilippo and Riedel, 1970, p. 454, figs. $21-23,27$.

\section{Lychnocanium grande Campbell and Clark}

Lychnocanoma grande (Campbell and Clark) in Kling, 1973, pl. 10, figs. 10-14.

Lychnocanium sp. cf. L. grande Campbell and Clark (Plate 1, Figures 21 and 22)

Lychnocanoma sp. A cf. L. grande (Campbell and Clark) in Kling, 1973, pl. 4, figs. 9, 10.

Remark: Individuals placed under this species are quite similar to L. grande but usually have a more robust thorax, a campanulate thorax, and smaller pores on the thorax. The abdominal segment seems to be better developed in most individuals than those of $L$. grande and may serve as a criterion in distinguishing the two species. There is an obvious gap in time between the first occurrence of this form and the last occurrence of $L$. grande.

\section{Pterocanium praetextum (Ehrenberg) eucolpum Haeckel}

Pterocanium praetextum (Ehrenberg) eucolpum Haeckel in Nigrini, 1967 , p. 70 , pl. 7 , fig. 2.

\section{Pterocanium praetextum praetextum (Ehrenberg)}

Pterocanium praetextum praetextum (Ehrenberg) in Nigrini, 1967, p. 68 , pl. 7 , fig. 1.

\section{Pterocanium trilobum (Haeckel)}

Pterocanium trilobum (Haeckel) in Nigrini, 1967, p. 71, pl. 7, figs. $3 a-b$.

\section{Dictyophimus sp.}

(Plate 1, Figures 23 and 24)

A dictyophimid with the legs forming from the cephalis and thorax. This form is extremely robust.

\section{Dictyophimus sp. cf. D. hirundo Haeckel}

(Plate 1, Figure 20)

Similar to $D$. hirundo except that the thorax is straighter.

Stichocorys armata (Haeckel)

Stichocorys armata (Haeckel) in Riedel and Sanfilippo, 1971, p. 1595, pl. 2E, figs. 13-15.

\section{Stichocorys delmontensis (Campbell and Clark)}

Stichocorys delmontensis (Campbell and Clark) in Westberg and Riedel, 1978, p. 22, pl. 3, figs. 1-5.

\section{Stichocorys diploconus (Haeckel)}

Stichocorys diploconus (Haeckel) in Sanfilippo and Riedel, 1970, p. 451 , pl. 1 , figs. 31,32 .

\section{Stichocorys peregrina (Riedel)}

Stichocorys peregrina (Riedel) in Westberg and Riedel, 1978, p. 22, pl. 3 , figs. 6-9.

\section{Theocalyptra bicornis (Popofsky)}

Theocalyptra bicornis (Popofsky) in Riedel, 1958, p. 240, pl. 4, fig. 4.

\section{Theocorys redondoensis (Campbell and Clark)}

Theocyrtis (Theocorusca) redondoensis Campbell and Clark, 1944, p. 49 , pl. 7 , fig. 4.

Theocorys redondoensis (Campbell and Clark) in Kling 1973, p. 638, pl. 11, figs. 26-28.

\section{Theocorys japonica (Nakaseko)}

Sethocyrtis japonica Nakaseko, 1963, p. 176, text fig. 9, pl. 1, figs. $10 \mathrm{a}, 10 \mathrm{~b}$

Remark: This species differs from $T$. redondoensis in being much smaller in size and in the shape of the thorax. It is probably the ancestor of $T$. redondoensis.

\section{ACKNOWLEDGMENTS}

Acknowledgment is made to the Donors of the Petroleum Research Fund, administered by the American Chemical Society, for partial support of this research through PRF Grant 8657-AC2 and to the Oceanography Section of the National Science Foundation for partial support through NSF Grant OCE74-21805. I thank F. M. Weaver for his review of the manuscript and R. E. Casey for his review and continued support in the preparation of the manuscript. C. J. Reynolds is most graciously acknowledged for her typing of the manuscript.

\section{REFERENCES}

Campbell, A. S., and Clark, B. L., 1944. Miocene radiolarian faunas from Southern California. Geol. Soc. Am. Spec. Paper, 51, 76.

Casey, R. E., 1972. Neogene radiolarian biostratigraphy and paleotemperatures: Southern California, the Experimental Mohole, Antarctic core E 14-8. Palaeogeogr., Palaeoclimatol., Palaeoecol., 12, 115-130.

Cox, A., 1969. Geomagnetic reversals. Science, 163, 237-245.

Ehrenberg, C. G., 1847. Ueber die Mikroscopischen Kisselschaigen Polycystnen als Machtiege Gebirgsmasse von Barbados. K. Preuss. Akad. Wiss. Monatsber. (for 1847), pp. 40-60.

Foreman, H. P., 1975. Radiolarians from the North Pacific, Deep Sea Drilling Project, Leg 32. In Larson, R. L., Moberly, R., et al., Init. Repts. DSDP, 32: Washington (U.S. Govt. Printing Office), 579-676.

Haeckel, E., 1862. Die radiolarien (Rhizopoda Radiolaria). Eine monographie: Berlin (Reimer), p. 572.

1881. Entwurf eines Radiolarien. Systems auf Grund von Studien der Challenger-Radiolarien. Jenaische Zeitschr. Naturwiss., 15, 418-472.

Hays, J. D., 1965. Radiolaria and late Tertiary and Quaternary history of Antarctic seas. Biology of Antarctic Seas II: Am. Geophys. Union, Antarctic Res. Series, 5, 125-184.

, 1970. The stratigraphy and evolutionary trends of Radiolaria in North Pacific deep-sea sediments. Geol. Soc. Am., Mem. 126, pp. 185-218.

Kling, S. A., 1973. Radiolaria from the eastern North Pacific, Deep Sea Drilling Project, Leg 18. In Kulm, L. D., von Huene, R., et al., Init. Repts. DSDP, 18: Washington (U.S. Govt. Printing Office), 617-671.

Knoll, A. H., and Johnson, D. A., 1975. Late Pleistocene evolution of the collosphaerid radiolarian Buccinosphaera invaginata Haeckel. Micropaleontology, 21 (No. 1), 60-68.

Moore, T. C., 1978. The distribution of radiolarian assemblages in the modern and ice-age Pacific. Mar. Micropaleont., 3, 229-266.

Müller, J., 1858. Über die thalassicollen, Polycystinen und Acanthometren des Mittelmeeres. Abh. Kgl. Akad. Wiss. Berlin, pp. 1-62.

Nakaseko, K., 1963. Neogene Cyrtoidea (Radiolaria) from the Isozaki Formation in Ibaraki Prefecture. Japan, Osaka Univ. Sci. Rept., 12 (2), 165-198.

Nigrini, C. A., 1967. Radiolaria in pelagic sediments from the Indian and Atlantic Oceans. Scripps Inst. Oceanogr. Bull., 11, 1-106. 
1971. Radiolarian zones in the Quaternary of the equatorial Pacific Ocean. In Funnell, B. M., and Riedel, W. R. (Eds.), Micropalaeontology of the Oceans: Cambridge (Cambridge University Press), pp. 443-461.

1977. Tropical Cenozoic Artostrobiidae (Radiolaria). Micropaleontology, 23 (No. 3), 241-269.

Petrushevskaya, M. G. 1967. Radiolarii otryadov Spumellaria i Nassellaria Antarkticheskoi oblasti (po materialam Sovetsko, Antarkticheskoi ekspeditsii). Issled. Fauny morei, 3, 5-186.

, 1971. On the natural system of Polycystine Radiolaria. Proc. II Plankt. Conf. Rome 1970, pp. 981-992.

1975. Cenozoic radiolarians of the Antarctic, Leg 29. In Kennett, J. P., Houtz, R. E., et al., Init. Repts. DSDP, 29: Washington (U.S. Govt. Printing Office), 541-675.

Petrushevskaya, M. G., and Kozlova, G., 1972. Radiolaria: Leg 14, Deep Sea Drilling Project. In Hayes, D. E., Pimm, A. C., et al., Init. Repts. DSDP, 14: Washington (U.S. Govt. Printing Office), 459-648.

Reynolds, R. A., in prep. Neogene Radiolaria of the Northwest Pacific, eastern boundary current system [Ph.D. dissert.]. Rice University, Houston.

Riedel, W. R., 1957. Radiolaria: a preliminary stratigraphy. Rept. Swed. Deep Sea Exped., 6 (No. 3), 61-96.

1958. Radiolaria in Antarctic sediment. B.A.N.Z. Antarctic Res. Exped. Rept., Series B, 6 (10), 217-255.
1967, Subclass Radiolaria. In Harland, W. B., et al. (Eds.), The Fossil Record: London (Geological Society of London), pp. 291-298.

, 1971. Systematic classification of Polycystine Radiolaria. In Funnell, B. M., and Riedel, W. R., (Eds)., Micropalaeontology of the Oceans: Cambridge (Cambridge University Press), pp. 649-661.

Riedel, W. R., and Sanfilippo, A., Radiolaria, Leg 4, Deep Sea Drilling Project. In Bader, R., Gerard, R. D., et al., Init. Repts. DSDP, 4: Washington (U.S. Govt. Printing Office), 503-575.

, 1971. Cenozoic Radiolaria from the western tropical Pacific, Leg 7. In Winterer, E. L., Riedel, W. R., et al., Init. Repts. DSDP, 7, Pt. 2: Washington (U.S. Govt. Printing Office), 1529-1672.

1977. Cainozoic Radiolaria. In Ramsay, A. T. S. (Ed.), Oceanic Micropalaeontology: Cambridge (Cambridge University Press), pp. 847-912.

1978. Stratigraphy and evolution of tropical Cenozoic radiolarians. Micropaleontology, 24 (No. 1), 61-96.

Sanfilippo, A., and Riedel, W. R., 1970. Post-Eocene "closed", theoperid radiolarians. Micropaleontology, 16 (No. 4), 446-462.

Westberg, M. J., and Riedel, W. R., 1978. Accuracy of radiolarian correlation in the Pacific Miocene. Micropaleontology, 24 (No. 1), 1-23. 


\section{PLATE 1}

(For each figure the following information is given: sample number, with intervals in $\mathrm{cm}$; England Finder coordinates; slide number; and maximum dimension in $\mu \mathrm{m}$.)

Figures 1-4 Collosphaera sp. A

1. 438A-79-4, 102-104, Z 4/3, Sl. 1, 105.

2. 438A-79-6, 102-104, Q 22/2, Sl. 2, 80 (end view).

3. 440B-68-1, 21-22, S 37/2, Sl. 1, 95.

4. 438A-8-1, 37-39, X 41/2, Sl. 1, 130.

Figures 5-9 Collosphaera pyloma $\mathrm{n}$. sp.

5, 6. 438B-4-3, 37-40, U 1/3, Sl. 2, 105.

7, 8. 438A-78-3, 90-92, H 14/3, Sl. 1,125 (holotype).

9. 438A-68,CC, 0 44/3, Sl. 2, 90 (end view).

Figure $10 \quad$ Prunopyle titan form A

438A-73-2, 135-137, C 34/4, Sl. 1, 360.

Figures 11-14 Ommatartus sp.

11, 12. 438A-43-4, 49-51, M 16/3, Sl. 2, 200.

13, 14. 438A-49-5, 44-46, Y 20/4, Sl. 1, 230.

Figures 15, 16 Clathrocyclas cabrilloensis

15. 438B-2,CC, J 7/1, Sl. 1, 170.

16. $438 \mathrm{~A}-45-1,130-132$, W $23 / 4$, Sl. 2,140 .

Figures 17, 18 Lipmanella sp. aff. Theocorys redondoensis 17. 438A-30-4, 120-122, N 12/4, Sl. 2, 135. 18. 438A-29-6, 140-142, D 83/1, Sl. 1, 200.

Figure $19 \quad$ Lithocampe sp. 440B-56-3, 76-78, O 26/2, Sl. 1, 175.

Figure $20 \quad$ Dictyophimus sp. cf. D. hirundo 438A-13-1, 27-29, G 37/4, Sl. 1, 90.

Figures 21-22 Lychnocanium sp. cf. L. grande 440-5-1, 123-125, V 20/2, Sl. 1, 165.

Figures 23, 24 Dictyophimus sp. 438A-51-4, 130-132, Q 23/3, Sl. 2, 145. 
PLATE 1
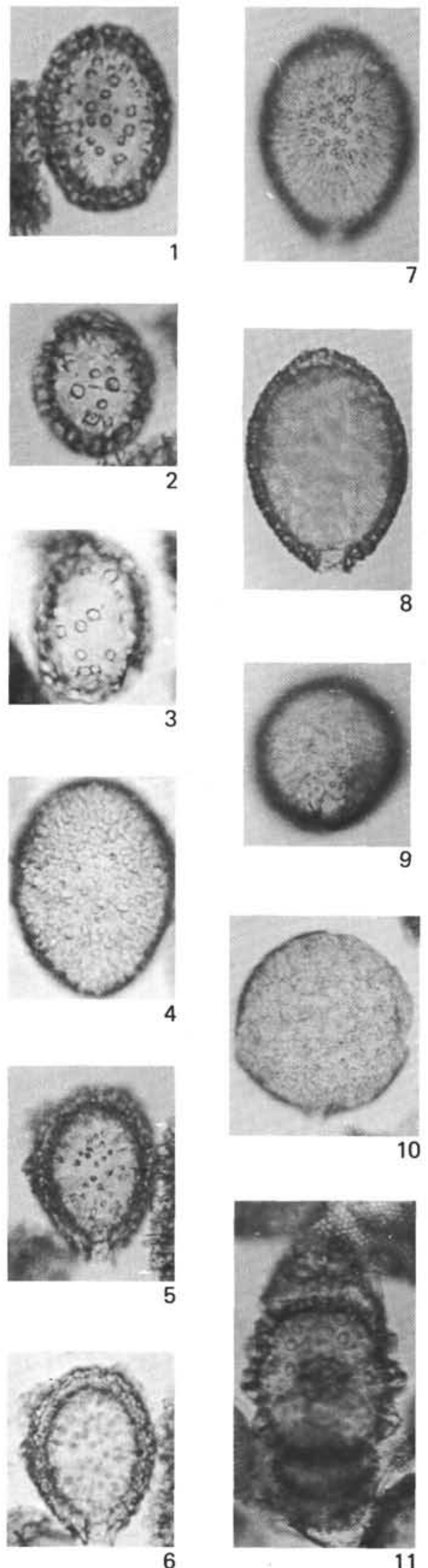
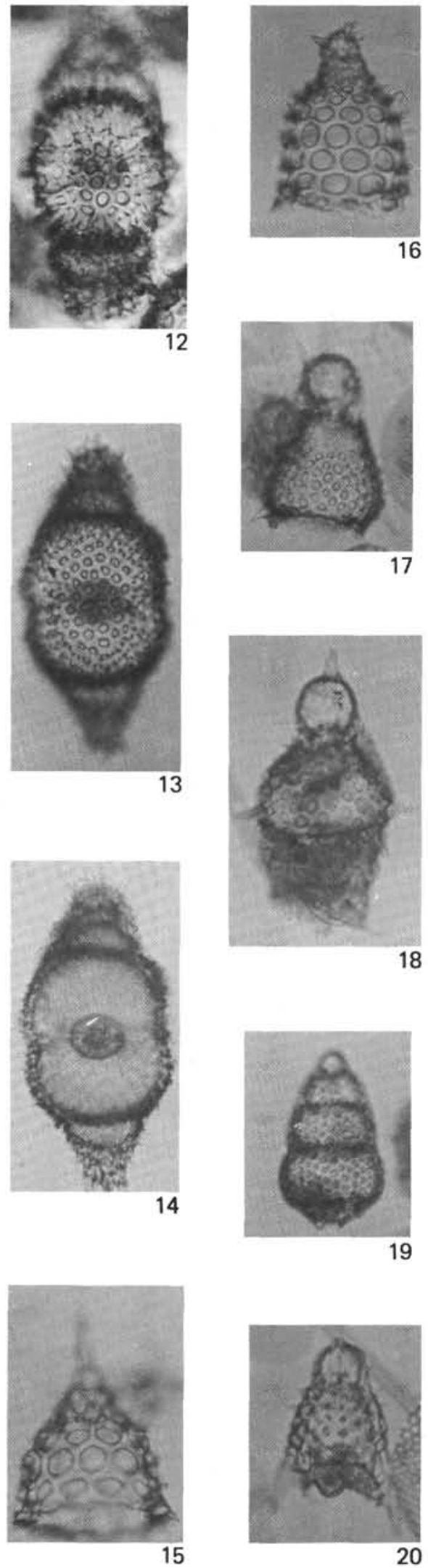
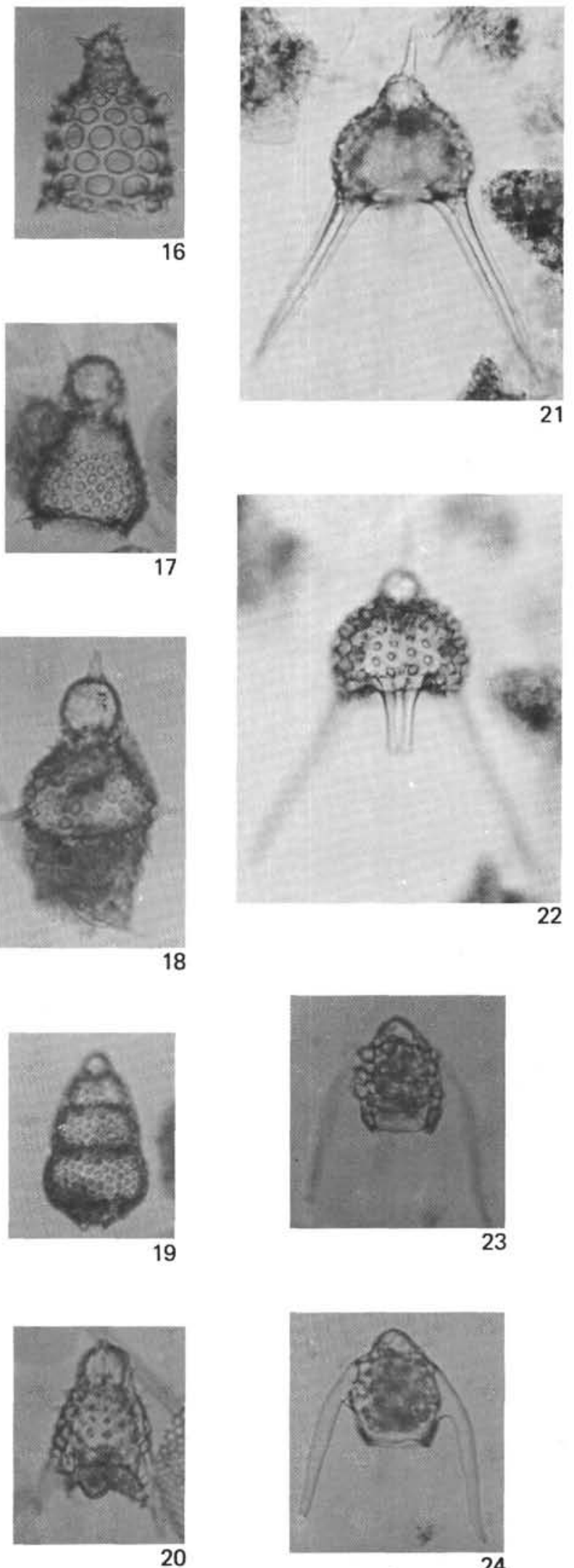

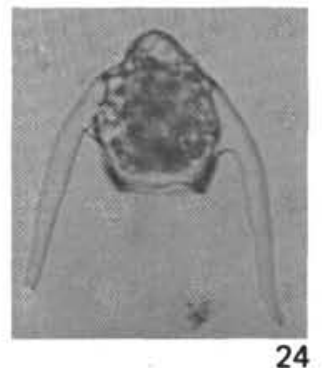

